\title{
DVA TIPA SREDNJOVJEKOVNIH NAUŠNICA S PODRUČJA HRVATSKE I BOSNE I HERCEGOVINE ${ }^{1}$ ZWEI TYPEN MITTELALTERLICHER OHRRINGE AUS KROATIEN UND BOSNIEN UND HERZEGOWINA
}

\author{
Maja Petrinec \\ Muzej hrvatskih arheoloških spomenika \\ Stjepana Gunjače 3 \\ HR - 21000 Split \\ petrinec65@gmail.com
}

\author{
Maja Petrinec \\ Museum der kroatischen archäologischen Denkmäler \\ Stjepana Gunjače 3 \\ HR - 21000 Split \\ petrinec65@gmail.com
}

UDK / UDC: UDK: 904: 671.121.4(497)"653"

Izvorni znanstveni rad/Original scientific paper

https://doi.org/10.52064/vamz.54.1.20

U razmatranje se uzimaju dva tipa naušnica koje se sporadično pojavljuju u okviru ranosrednjovjekovnih grobalja na teritoriju današnje Hrvatske i Bosne i Hercegovine; naušnice s ukrasom u obliku spiralnih vitica na donjem luku karike i naušnice sa spiralnim privjeskom. U literaturi se podjednako pripisuju tzv. bjelobrdskoj i ketlaškoj kulturi, ali i nekim drugim kulturnim skupinama. Široka rasprostranjenost, kao i raznoliko vremensko opredjeljivanje, upućuju na zaključak da u oba slučaja nije riječ o jedinstvenim niti vremenski podudarnim skupinama naušnica. Najučestalije su u razdoblju od 9. do 12. stoljeća.

Ključne riječi:

arheološke kulture, naušnice s ukrasom u obliku spiralnih vitica, naušnice sa spiralnim privjeskom, nakit

\section{Ukratko o arheološkim kulturama i njihovu nazivlju}

Naušnice s ukrasom u obliku spiralnih vitica na donjem luku karike i naušnice sa spiralnim privjeskom u starijoj su domaćoj, ali i stranoj arheološkoj literaturi pripisivane podjednako tzv. bjelobrdskoj i ketlaškoj kulturi. ${ }^{3}$ Kako su se u manjem broju pojavile i na pojedinim grobljima u hrvatskom priobalju i njegovu zaleđu, smatrane su importom s područja tih kultura na područje starohrvatske kulture. ${ }^{4}$
Betrachtet werden hier zwei Typen von Ohrringen, die auf frühmittelalterlichen Gräberfeldern auf dem Gebiet des heutigen Kroatiens und Bosnien und Herzegowinas sporadisch vorkom men. Es handelt sich hierbei um Ohrringe mit einer Verzierung in Form von spiralförmigen Ranken am unteren Bogen des Ringleins und Ohrringe mit spiralförmigem Anhänger. In der Literatur werden sie gleichermaßen der sogenannten Bijelo Brdo- und Köttlach-Kultur zugeordnet, aber auch einigen anderen Kulturgruppen. Die weite geographische Verbreitung sowie die unterschiedliche zeitliche Zuordnung lassen darauf schließen, dass es sich in beiden Fällen nicht um einzigartige oder zeitlich übereinstimmende Gruppen von Ohrringen handelt. Am häufigsten traten sie in der Zeit vom 9. bis zum 12. Jahrhundert auf.

Schlüsselwörter:

archäologische Kulturen, Ohrringe mit Verzierungen in Form von spiralförmigen Ranken, Ohrringe mit spiralförmigem Anhänger, Schmuck

Eine kurze Zusammenfassung über archäologische Kulturen und ihre Terminologie ${ }^{2}$

Ohrringe mit Verzierungen in Form von spiralförmigem Ranken im unteren Bogen des Rings und Ohrringe mit spiralförmigem Anhänger wurden in der älteren kroatischen, aber auch in der ausländischen archäologischen Literatur gleichermaßen der sogenannten Bijelo Brdo- und Köttlach-Kultur zugeschrieben. ${ }^{3}$ Da man sie in geringerer Anzahl auf einigen Gräberfeldern an der kroatischen Küste und dessen Hinterland vorfand, wurden sie als Importe aus dem Gebiet dieser Kulturen in das Gebiet der altkroatischen Kultur betrachtet. ${ }^{4}$

\footnotetext{
$1 \quad$ Tekst posvećujem dragom kolegi dr. sc. Željku Demi.

Na ovu problematiku opširnije se osvrćem u jednom drugome tekstu koji je u pripremi.

Za ketlašku kulturu, vidi (Korošec 1979; Giesler 1980; Eichert 2010; Ungerman 2016). Za bjelobrdsku kulturu, vidi (Váňa 1954; Vinski 1970; Giesler 1981; Tomičić 1992; Demo 1996, 42; Demo 2009, 552).

$4 \quad$ Karaman 1940, 29, sl. 27; 34; Jelovina 1976, 103-106; Cetinić 2011, 197.
}

\footnotetext{
1 Diesen Text widme ich meinem werten Kollegen Dr. Sc. Željko Demo.

Auf diese Problematik gehe ich in einem anderen Text, der in Vorbereitung ist, näher ein.

Für die Köttlach-Kultur, siehe (Korošec 1979; Giesler 1980; Eichert 2010; Ungerman 2016). Für die Bijelo Brdo-Kultur, siehe (Váňa 1954; Vinski 1970; Gies ler 1981; Tomičić 1992; Demo 1996, 42; Demo 2009, 552).

4 Karaman 1940, 29, Abb. 27; 34; Jelovina 1976, 103-106; Cetinić 2011, 197
} 
U novije su vrijeme i bjelobrdska i ketlaška kultura dovedene u pitanje kao jedinstvene pojave u onom smislu u kojem ih je određivala arheološka literatura druge polovine 20. stoljeća pa se ti nazivi sve češće pojavljuju u navodnim znakovima. ${ }^{5}$

Za razliku od potonjih, pojam starohrvatske kulture nikad nije bio općeprihvaćen niti je ona bila teritorijalno i vremenski određena; nisu bili definirani njezini razvojni stupnjevi, kao što nije bio izdvojen niti njezin tipični nalazni repertoar. ${ }^{6}$ Češće se, ali također bez jasnih odrednica, u literaturi pojavljivao termin dalmatinsko-hrvatska kulturna skupina. Oba termina koriste se još i danas.

Prve kritike uporabe izraza „starohrvatski“ u domaćoj literaturi pojavile su se u zadnja dva desetljeća 20. stoljeća, a bazirale su se na pretpostavci da je u ranim stoljećima srednjeg vijeka (posebno u 7. i 8. stoljeću) udio slavenskog / hrvatskog stanovništva bio neznatan u odnosu na ostatke romanske ili romanizirane populacije u onim dijelovima Dalmacije u kojima će se kasnije formirati ranosrednjovjekovna hrvatska kneževina. Te su kritike također polazile od raznih teorija o doseljenju Hrvata u Dalmaciju tek u 9. stoljeću. Dakle, i u slučaju uporabe i u slučaju odbacivanja izraza "starohrvatski“ radilo se o etničkim konotacijama, odnosno o određivanju etničke pripadnosti na osnovu arheoloških nalaza i djelomično na reinterpretaciji pojedinih povijesnih izvora. ${ }^{7}$

Daljnje kritike s početka 21. stoljeća temelje se na postprocesualističkom viđenju materijalne kulture prema kojem je neprihvatIjivo njezino povezivanje s etničkom pripadnošću. Polazi se od toga da su predmeti sami po sebi neutralni, a jedino kontekst u kojem su se koristili kazuje nešto o identitetima koje su možda mogli projicirati. Predmeti u funkciji grobnih priloga, jednako kao ni sam ritual sahranjivanja, ne potvrđuju etnicitet ljudi koji su ih upotrebljavali. Na tragu tih razmišljanja pojavljuju se mišljenja da se na prostoru postrimske Dalmacije, na kojem će u 9. stoljeću nastati hrvatska kneževina, arheološka baština ne može označiti kao „starohrvatska“. Autori, koji se zalažu za ovaj pristup, također negiraju i postojanje Slavena kao jedne od etničkih i jezičnih europskih skupina, smatrajući ih izmišljotinom bizantskih pisaca koji su tim imenom nazivali raznorodne skupine naseljene iza justinijanskog limesa. Prema njima, na prostoru Dalmacije dogodila se transformacija identiteta indigene populacije koja postaje "Slavenima“. ${ }^{8}$ Kao dodatnu potvrdu svojim zaključcima, ovi autori dovode u pitanje vjerodostojnost gotovo svih poznatih povijesnih izvora koji se odnose na navedeno razdoblje. lako se navodno zalažu za neutralnost materijalne kulture, često posežu upravo za arheološkim nalazima i grobnim ritualima kao potvrdama etničke pripadnosti, odnosno nepripadnosti ili prisutnosti, tj. neprisutnosti nekog etnika na određenom području. U svojim najnovijim radovima D. Džino posebno se zalaže
In jüngster Zeit wurden sowohl die Bijelo Brdo- als auch die Köttlach-Kultur als einzigartige Erscheinungen in dem Sinne in Frage gestellt, in dem sie durch die archäologische Literatur der zweiten Hälfte des 20. Jahrhunderts bestimmt wurden, so dass ihre Bezeichnungen immer häufiger in Anführungszeichen auftreten. ${ }^{5}$

Im Gegensatz zu den zuvor genannten Kulturen wurde der Begriff altkroatische Kultur hingegen niemals allgemein anerkannt noch territorial und zeitlich bestimmt; die Entwicklungsstadien der Kultur waren weder definiert, noch wurde ihr typisches Fundrepertoire klar abgegrenzt. ${ }^{6}$ Der Begriff dalmatinisch-kroatische Kulturgruppe tauchte in der Literatur häufiger auf, aber auch ohne klare Determinanten. Beide Begriffe sind heute immer noch in Verwendung.

Die ersten Kritiken am Gebrauch des Begriffs „Altkroatisch“ in der heimischen Literatur erschienen in den 8oern und goern Jahren des 20. Jahrhunderts und beruhten auf der Annahme, dass in den frühen Jahrhunderten des Mittelalters (insbesondere im 7. und 8. Jahrhundert) der Anteil der slawischen/kroatischen Bevölkerung relativ unbedeutend war, im Verhältnis zur übrigen romanischen oder romanisierten Bevölkerung in jenen Gebieten Dalmatiens, in denen später das frühmittelalterliche Kroatische Fürstentum gebildet wurde. Auch diese Kritiken basierten auf verschiedenen Theorien, die besagten, dass die Einwanderung der Kroaten nach Dalmatien erst im 9. Jahrhundert stattfand. Sowohl bei der Verwendung als auch bei der Ablehnung des Begriffs „Altkroatisch“ handelte es sich also um ethnische Konnotationen, bzw. um die Bestimmung der ethnischen Zugehörigkeit auf Grundlage archäologischer Funde und teilweise der Neuinterpretation bestimmter historischer Quellen.?

Weitere Kritiken vom Beginn des 21. Jahrhunderts beruhen auf der postprozessualen Sichtweise der materiellen Kultur, nach der ihr Verbinden mit der ethnischen Zugehörigkeit inakzeptabel ist. Der Ausgangspunkt hierbei ist, dass Gegenstände an sich neutral sind und dass nur der Kontext ihrer Verwendung etwas über die Identitäten aussagt, die sie möglicherweise projizieren konnten. Gegenstände in der Funktion von Grabbeigaben sowie das Bestattungsritual selbst bestätigen nicht die ethnische Zugehörigkeit der Menschen, die sie verwendet haben. Im Sinne solcher Ansichtsweisen treten auch Meinungen auf, dass im Gebiet des poströmischen Dalmatiens, wo im 9. Jahrhundert das Kroatische Fürstentum gebildet wurde, das archäologische Erbe nicht als „altkroatisch“ bezeichnet werden kann. Autoren, die diesen Ansatz befürworten, bestreiten zudem die Existenz der Slawen als eine der ethnischen und sprachlichen europäischen Gruppen. Sie betrachten diese als eine Erfindung byzantinischer Schriftsteller, die den unterschiedlichen Grup-
Za ketlašku kulturu s osvrtom na stariju literaturu, vidi Eichert (2010, 1417). Za bjelobrdsku kulturu s osvrtom na stariju literaturu, vidi Filipec $(2012,227-$ 232).

6 Opširnije, vidi Petrinec (2014, 89-92).

$7 \quad$ Petrinec 2015, 106-130 (gdje je navedena i sva relevantna literatura i svi radovi A. Miloševića koji se najviše bavio ovom problematikom).

8 Curta 2001; 2010; Džino 2008; 2009.
Für die Köttlach-Kultur mit Referenz auf die ältere Literatur, siehe Eichert 2010, 14-17. Für die Bijelo Brdo-Kultur mit Referenz auf die ältere Literatur, siehe Filipec (2012, 227-232).

6 Ausführlicher, siehe Petrinec (2014, 89-92).

Petrinec 2015, 106-130 (wo auch die gesamte relevante Literatur und alle Arbeiten von A. Milošević angeführt sind, der sich mit dieser Problematik am meisten beschäftigte). 
za diskontinuitet između grobalja na redove 8. i ranog 9. stoljeća i onih nešto mlađih, koja smatra dokazom doseljenja nove populacije u Dalmaciju u 9. stoljeću. ${ }^{9}$

Koncept arheoloških kultura, pa u tom kontekstu i starohrvatske kulture, u svom je opsežnom doktorskom radu u najnovije vrijeme kritizirao G. Bilogrivić. ${ }^{10}$ Starohrvatska kultura prema ovom je autoru znanstveni konstrukt razvijen od sredine 20. stoljeća na temeljima dotadašnjih tumačenja „starohrvatskih“ arheoloških nalaza, u okviru prevladavajućega kulturno-povijesnog pristupa u tadašnjoj arheologiji, po čemu se ne razlikuje od sličnih koncepata drugdje u Europi. Glavna je zamjerka tom konceptu izravno povezivanje materijalne kulture (arheoloških nalaza) s određenim etnikom. Bilogrivić ističe kako se „starohrvatska kultura" svojim rasprostiranjem ne poklapa s cijelom ranosrednjovjekovnom Hrvatskom, niti se na području potonje nalazi samo ta jedna arheološka kultura. Vremenski ona ne odgovara periodu vlasti „hrvatske narodne dinastije“, pojavljuje se i prije nego što se sa sigurnošću zna za prisutnost Hrvata u Dalmaciji i nestaje prije smjene dinastije na početku 12. stoljeća. Arheološki materijal, koji je obilježava, uvelike je stranoga podrijetla ili je nastao prema stranim uzorima te se ne pokazuje kao jasnodefinirana i zaokružena cjelina. Velikim problemom smatra etničke konotacije u njezinu imenu, koje implicira da se radi isključivo o ostavštini ranosrednjovjekovnih Hrvata, čime se, prema njegovu mišljenju, zanemaruje postojanje drugih znanih i neznanih skupnih identiteta na istom području.

Kada se govori o bjelobrdskoj, ketlaškoj i starohrvatskoj kulturi, treba imati na umu da su prve dvije definirane uglavnom na materijalu dobivenom arheološkim istraživanjima srednjovjekovnih grobalja, ${ }^{11}$ dok su se pod nazivom starohrvatska kultura (ponekad i umjetnost) uz arheološke grobne nalaze podrazumijevali svi spomenici i druge manifestacije ranoga srednjeg vijeka na području hrvatske kneževine / kraljevine (uključujući predromaničku i ranoromaničku arhitekturu i skulpturu).

Ostavljajući ovdje po strani teorijske rasprave o arheološkim kulturama, smatram da je u okviru ranosrednjovjekovne arheologije nemoguće, a i nepotrebno, u potpunosti izbjegavati kulturno-povijesni pristup arheološkome materijalu. Također, kada je riječ o arheološkim nalazima koji pripadaju razdobljima pisane povijesti, nije moguće ostati potpuno neutralan pri njihovoj interpretaciji. To, međutim, ne znači da se zalažem za izravno povezivanje arheoloških nalaza s određenim etnikom, kao što ni svaku pojedinačnu pojavu određenih arheoloških nalaza zasigurno ne smatram dokazom prisutnosti pripadnika nekog etnika na nekom području. S druge strane, apsurdno je i svaki predmet, koji nije karakterističan za materijalnu kulturu pojedinog područja, proglašavati importom, što je često bio slučaj baš u hrvatskoj arheološkoj literaturi druge polovine 20. stoljeća. pen, die hinter dem Limes von Justinian lebten, diesen Namen gaben. Diesen Autoren zufolge fand in Dalmatien eine Identitätsumwandlung der einheimischen Bevölkerung in "Slawen“ statt. ${ }^{8}$ Als zusätzliche Bestätigung ihrer Schlussfolgerungen stellen diese Autoren die Glaubwürdigkeit fast aller bekannten historischen Quellen bezüglich dieser Zeit in Frage. Obwohl sie angeblich die Neutralität der materiellen Kultur befürworten, greifen sie sehr oft auf gerade diese archäologischen Funde und Grabrituale zurück, um die ethnische Zugehörigkeit oder Nichtzugehörigkeit bzw. die Anwesenheit oder das Fehlen einer ethnischen Gruppe in einem bestimmten Gebiet zu bestätigen In seinen neuesten Arbeiten befürwortet D. Dzino insbesondere die Diskontinuität zwischen den Reihengräberfeldern des 8 und frühen 9. Jahrhunderts und den etwas jüngeren, die er als Beweis für die Einwanderung einer neuen Bevölkerung nach Dalmatien im 9. Jahrhundert ansieht. ${ }^{9}$

Das Konzept der archäologischen Kulturen, und in diesem Kontext auch der altkroatischen Kultur, kritisierte G. Bilogrivić jüngst in seiner umfassenden Dissertation. ${ }^{10}$ Laut diesem Autor ist die altkroatische Kultur ein wissenschaftliches Konstrukt, das ab Mitte des 20. Jahrhunderts auf der Grundlage bisheriger Interpretationen "altkroatischer" archäologischer Funde entwickelt wurde, im Rahmen des damals in der Archäologie vorherrschenden kulturhistorischen Ansatzes, der sich von ähnlichen Konzepten in anderen Teilen Europas nicht unterscheidet Die maßgebliche Kritik an diesem Konzept ist die direkte Verknüpfung der materiellen Kultur (der archäologischen Funde) mit einer bestimmten ethnischen Gruppe. Bilogrivić weist darauf hin, dass die "altkroatische Kultur" und ihr Ausbreitungsgebiet weder mit dem gesamten Territorium des frühmittelalterlichen Kroatiens überlappt noch, dass es in diesem Gebiet eben nur diese eine archäologische Kultur gibt. Zeitlich gesehen entspricht sie nicht der Regierungszeit der „kroatischen Volksdynastie“, die Kultur tritt in Erscheinung noch bevor die Anwesenheit der Kroaten in Dalmatien sicher bekannt ist und schwindet vor dem Dynastiewechsel zu Beginn des 12. Jahrhunderts. Das archäologische diese Kultur kennzeichnende Material ist größtenteils ausländischen Ursprungs oder wurde nach ausländischen Vorbildern erstellt, und zeigt sich nicht als klar definiertes und abgerundetes Ganzes. Als ein großes Problem betrachtet Bilogrivić auch die ethnischen Konnotationen in ihrem Namen, welcher impliziert, dass es sich ausschließlich um das Erbe frühmittelalterlicher Kroaten handelt. Damit, so der Autor, bleibt die Existenz anderer bekannter und unbekannter Gruppenidentitäten im selben geographischen Raum unberücksichtigt.

Wenn man über die Bijelo Brdo-, Köttlach- und altkroatische Kultur spricht, ist zu beachten, dass die beiden ersten Kulturen hauptsächlich anhand Materials aus archäologischen Unter-
9 Džino 2021a; 2021b. Poseban osvrt zahtjeva članak o bazilici i grobovima u Ljupču (Džino 2018), kao i najnovija knjiga istog autora (Džino 2021b), ali to izlazi izvan okvira ovdje zadane teme.

10 Usp. Bilogrivić 2016; Vidi i Bilogrivić 2019.

11 Siznimkom P. Korošec (1979) koja uzima u obzir i druge kategorije nalazišta i nalaza.

\footnotetext{
8 Curta 2001; 2010; Džino 2008; 2009

Džino 2021a; 2021b. Eine besondere Bezugnahme erfordert der Artikel über die Basilika und Gräber in Ljubač (Džino 2018) sowie das neueste Buch die ses Autors (Džino 2021b), dies geht jedoch über den Rahmen des hier angegebenen Themas hinaus

10 Vergleiche Bilogrivić 2016; Siehe auch Bilogrivić 2019.
} 
U tekstu koji slijedi bit će isključivo riječi o nakitu, uglavnom iz ranosrednjovjekovnih grobova. Stoga, prihvaćam da je usko pripisivanje pojedinih primjeraka jednoj od triju gore navedenih kultura uvijek predstavljalo ograničavajući faktor iako je bilo posve u skladu s tadašnjim načinom interpretacije arheoloških nalaza, kako u Hrvatskoj tako i drugdje u srednjoj i jugoistočnoj Europi. Naglašavam da meni uopće nije sporno da je znatan dio arheološkog materijala, pa tako i srednjovjekovnog nakita, vezan uz područja prvih ranosrednjovjekovnih država, kako u vrijeme njihova nastanaka tako i kasnije (za europski prostor koji je ovdje od interesa to je osobito izraženo u Moravskoj, Hrvatskoj i Bugarskoj). Naručitelji i nositelji nakita bili su zasigurno stanovnici tih prvih kneževina. Ipak, to ništa ne govori o podrijetlu pojedinih tipova nakita pa niti o tome gdje je proizveden, kao ni o etničkoj pripadnosti njegovih nositelja i obrtnika koji su ga izradili.

Također, u daljnjem tekstu nazive ketlaški, bjelobrdski i starohrvatski, kao i pojedine druge slične odrednice (avaroslavenski, velikomoravski, komanski), neću stavljati pod navodne znakove, ali ne zato što inzistiram na tom nazivlju, već zbog prepoznatljivosti i uvriježenosti njegove uporabe u starijoj literaturi na koju se osvrćem.

\section{Naušnice s ukrasom u obliku spiralnih vitica na donjem luku karike}

Na području današnje Hrvatske i Bosne i Hercegovine otkrivena je ukupno 21 naušnica ovog tipa; od toga je sedam parova i sedam pojedinačnih primjerka (kat. br. 1-11; karta 1 ). U većini slučajeva radi se o grobnim nalazima, a i za one nedovoljno poznatih okolnosti otkrića može se pretpostaviti isto. Ukupno je 16 naušnica načinjeno od bronce (pet parova i šest pojedinačnih primjeraka), a pet od srebra (dva para i jedan pojedinačni primjerak). $\mathrm{Na}$ četiri para pojavljuju se i drugi ukrasi u donjoj polovini karike (u tri slučaja riječ je o zrnima staklene paste, a u jednom o kuglastoj limenoj jagodi). Među potpuno sačuvanim primjercima 13 ih se pričvršćivalo pomoću kukice i ušice, a tri primjerka imaju završetke u obliku S-petlje. Kod jednog para i jednoga pojedinačnog primjerka krajevi karika su ravno odrezani, a kod ostalih, s obzirom na stupanj oštećenosti, način pričvršćivanja nije moguće utvrditi.

Dva primjerka potječu iz Istre, oba s istoga groblja (kat. br. ıa-b). Radi se o brončanim naušnicama iz grobova 43 i 47 na lokalitetu Dvigrad - Kacavanac. Jedan je par otkriven na grobu 197 na Gorici (Stranče) u Vinodolu (kat. br. 2). U Dalmaciji su registrirane na Ždrijacu u Ninu (grob 93) (kat. br. 3), na Begovači u Biljanama Donjim (grobovi 202, 231, 256) (kat. br. 10a-c), na Mastirinama u Kašiću (grob 66) (kat. br. 7), na Stombratama u Bijaćima (grob 33) (kat. br. 11), na Crkvini u Galovcu (pojedinačni primjerak otkriven izvan groba) (kat. br. 8) i na Crkvini u Biskupiji (grobni nalaz nepoznatih okolnosti otkrića) (kat. br. 4). S područja sjeverne Hrvatske potječe jedan primjerak otkriven u grobu 155 u Stenjevcu (Zagreb) (kat. br. 6). U Bosni i Hercegovini jedna je naušnica otkrivena na groblju Mahovljani - Kužno groblje (grob 3) (kat. br. 5), a jedan par potječe iz Župče (kat. br. 9).

Na prvi pogled čini se da je najveća koncentracija ovih nalaza u hrvatskom priobalju i njegovu neposrednom zaleđu, pri čemu se suchungen mittelalterlicher Gräberfelder ${ }^{11}$ definiert wurden. Der Name altkroatische Kultur (und manchmal auch Kunst) hingegen beinhaltet, abgesehen von den archäologischen Grabfunden, alle Denkmäler und sonstige Ereignisse des frühen Mittelalters auf dem Gebiet des Kroatischen Fürstentums/Königreichs (einschließlich vorromanische und frühromanische Architektur und Skulptur).

Auf die theoretischen Diskussionen über archäologische Kulturen nicht näher eingehend, bin ich der Meinung, dass es im Rahmen der frühmittelalterlichen Archäologie nicht nur unmöglich, sondern auch unnötig ist, den kulturhistorischen Ansatz an das archäologische Material vollständig zu meiden. In Bezug auf archäologische Funde aus schriftlich belegten historischen Epochen ist es zudem kaum möglich, eine komplett neutrale Bezeichnung bei deren Interpretation zu bewahren. Dies bedeutet jedoch nicht, dass ich die Ansicht vertrete, dass archäologische Funde direkt mit einer bestimmten ethnischen Zugehörigkeit verknüpft werden. Ebenso betrachte ich aber auch nicht jedes vereinzelte Vorkommen bestimmter archäologischer Funde als Beweis für die Anwesenheit von Angehörigen einer bestimmten ethnischen Gruppe in einem Gebiet. Andererseits ist es absurd, jeden Gegenstand, der für die materielle Kultur eines bestimmten Gebiets nicht charakteristisch ist, als Import zu deklarieren, was in der kroatischen archäologischen Literatur der zweiten Hälfte des 20. Jahrhunderts sehr häufig der Fall war.

Der nachfolgende Text handelt ausschließlich von Schmuck aus vorwiegend frühmittelalterlichen Gräbern. Daher akzeptiere ich, dass die enge Zuordnung einzelner Exemplare zu einer der drei oben genannten Kulturen immer einen einschränkenden Faktor darstellte, obwohl dies völlig im Einklang mit der damaligen Interpretationsweise der archäologischen Funde nicht nur in Kroatien, sondern auch in anderen Teilen Mittel- und Südosteuropa war. Ich betone, dass es meiner Meinung nach überhaupt nicht umstritten ist, dass ein bedeutender Teil des archäologischen Materials, einschließlich mittelalterlichen Schmucks, mit den Gebieten der ersten frühmittelalterlichen Staaten zusammenhängt, sowohl zum Zeitpunkt seiner Entstehung als auch später (für den europäischen Raum, der hier von Interesse ist, ist es besonders in Mähren, Kroatien und Bulgarien ausgeprägt). Sowohl jene, die ihre Anfertigung in Auftrag gaben, als auch die Träger des Schmucks waren sicherlich Bewohner dieser ersten Fürstentümer. Dies sagt jedoch nichts über die Herkunft bestimmter Typen von Schmuck aus, noch darüber, wo dieser angefertigt wurde. Ferner liefert es keine Informationen über die ethnische Zugehörigkeit seiner Träger und Kunstschmiede, die ihn hergestellt haben.

Zudem sind im folgenden Text die Namen Köttlach, Bijelo Brdo und altkroatisch sowie einige andere ähnliche Determinanten (awaroslawisch, großmährisch, komanisch) nicht in Anführungszeichen gesetzt, und zwar nicht, weil ich auf dieser Terminologie bestehe, sondern aufgrund ihrer Wiedererkennung und ihrem allgemein üblichen Gebrauch in der älteren Literatur, auf die ich mich hier beziehe.

11 Mit Ausnahme von P. Korošec, die auch andere Kategorien von Fundorten und Funde berücksichtigt (Korošec 1979). 


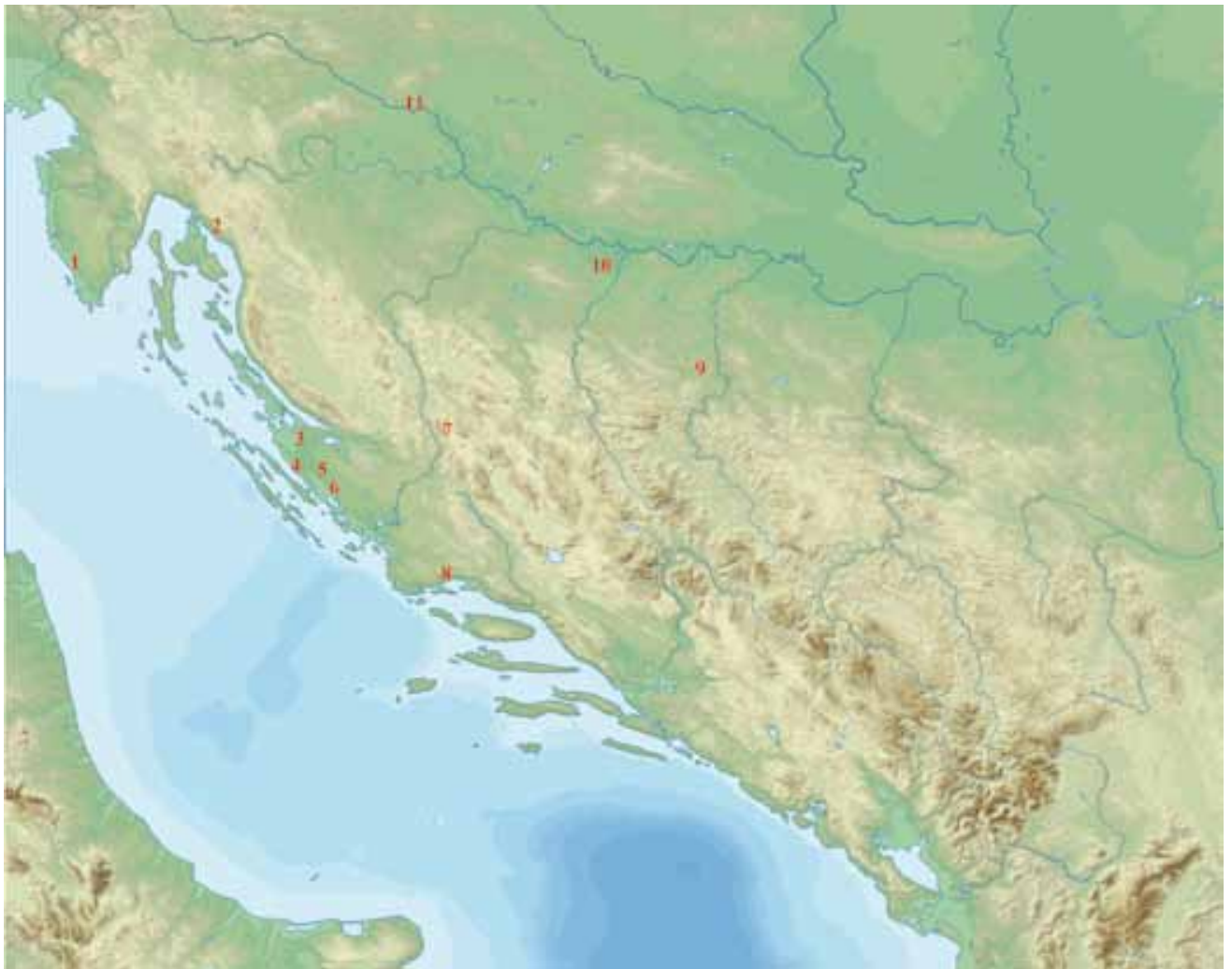

KARTA 1. Naušnice kojima je donja polovina karike obavijena viticama od spiralne žice:

1 - Dvigrad, 2 - Stranče, 3 - Nin, 4

- Galovac, 5 - Kašić, 6 - Biljane Donje, 7 - Biskupija, 8 - Bijaći, 9 - Župča, 10 - Mahovljani, 11 - Zagreb Stenjevec (izradila M. Petrinec).

KARTE 1. Ohrringe, deren untere Ringhälfte mit Ranken aus spiralförmig gewundenem Draht um wunden ist: 1-Dvigrad, 2-Stranče, 3-Nin, 4-Galovac, 5-Kašić, 6-Biljane Donje, 7-Biskupija, 8-Bijaći, 9 Župča, 10-Mahovljani, 11- Zagreb Stenjevec (hergestellt von $M$. Petrinec)

lokaliteti s kojih potječu mogu povezati sa značajnim središtima prve hrvatske kneževine u Dalmaciji, uključujući vinodolski nalaz, dok se izvan tog prostora pojavljuju sporadično. Međutim, kad se detaljnije razmotre svi predočeni nalazi, dolazimo do potpuno drugačijeg zaključka.

Starija hrvatska arheološka literatura nije se detaljnije bavila ovim naušnicama. Lj. Karaman ih je zajedno s nekim drugim tipovima pripisao karantansko-ketlaškoj kulturi, smatrajući ih stranim importima na područje Hrvatske. ${ }^{12}$ D. Jelovina općenito piše o naušnicama karantanske i bjelobrdske kulture, ne ulazeći dublje u razradu pojedinih tipova. ${ }^{13}$ Naušnice iz groba 66 na Mastirinama u Kašiću, prema terminologiji prisutnoj u stranoj literaturi, označava kao pilinski tip (prema nalazima iz groba 74 na lokalitetu Piliny I u Mađarskoj), smatra ih karakterističnima za panonski prostor te datira u 11 . stoljeće. ${ }^{14} \mathrm{Na}$ istom su tragu i zaključci $\mathrm{N}$. Jakšića. ${ }^{15}$ Nalaz iz groba 179 na Gorici u Stranču Ž. Cetinić također pripisuje bjelobrdskom kulturnom krugu i datira u 11. stoljeće. ${ }^{16} \mathrm{~J}$. Belošević 1980. godine samo usputno spominje primjerak iz groba 93 na Ždrijacu u Ninu, uz konstataciju da je imao ukrasnu aplikaciju koja nije u potpunosti sačuvana, a 2007. godine uopće ga ne spominje u tekstu. ${ }^{17}$ Sukladno ostalim hrvatskim autorima,

\footnotetext{
12 Karaman 1940, 34-35.

13 Jelovina 1976, 103-106.

14 Jelovina 1982, 59-60

15 Jakšić 1989, 429-430

16 Cetinić 2011, 197-199

17 Belošević 1980; 2007.
}

\section{Ohrringe mit Verzierungen in Form von spiralförmigem Ranken im unteren Bogen des Rings}

Im heutigen Kroatien sowie in Bosnien und Herzegowina wurden insgesamt 21 Ohrringe dieses Typs entdeckt, sieben Paare und sieben einzelne Exemplare (Kat. Nr. 1-11; Karte 1). In den meisten Fällen handelt es sich um Grabfunde. Gleichwohl wird angenommen, dass auch die Exemplare mit unzureichend bekannten Entdeckungsumständen Grabfunde darstellen. Insgesamt 16 Ohrringe wurden aus Bronze (fünf Paare und sechs Einzelstücke) und fünf aus Silber (zwei Paare und ein Einzelstück) hergestellt. Vier Paare weisen auch andere Verzierungen in der unteren Hälfte des Ringleins auf (in drei Fällen handelt es sich um winzige Glasperlen und in einem Fall um eine kugelförmige Beere aus Blech). Von den vollständig erhaltenen Exemplaren haben 13 einen Haken-Ösenverschluss und drei Exemplare Enden in Form einer S-Schleife. Bei einem Paar und einem Einzelexemplar sind die Ringenden gerade abgeschnitten. Der Verschluss kann aufgrund des Ausmaßes der Beschädigungen bei den anderen Exemplaren nicht bestimmt werden.

Zwei Exemplare stammen aus Istrien, beide vom selben Gräber feld (Kat. Nr. 1a-b). Es handelt sich dabei um Bronzeohrringe aus den Gräbern 43 und 47 am Fundort Dvigrad-Kacavanac. Ein Paar wurde im Grab 197 in Stranče (Gorica) in Vinodol (Kat. Nr. 2) entdeckt. Die dalmatinischen Funde stammen aus Ždrijac in Nin (Grab 93) (Kat. Nr. 3), Begovača in Biljane Donje (Gräber 202, 231, 256) (Kat. Nr. 10a-c) und Mastirine in Kašić (Grab 66) (Kat. Nr. 7), Stombrate in Bijaći (Grab 33) (Kat. Nr. 11), Crkvina in Galovac (außerhalb des Grabes entdecktes Einzelexemplar) 
naušnicu s Crkvine u Galovcu određuje kao pilinski tip koji pripada bjelobrdskome kulturnom krugu. ${ }^{18} \mathrm{~V}$. Sokol ovaj tip naušnica uopće ne uzima u razmatranje. ${ }^{19}$

Premda među nakitom s Kacavanca u Dvigradu B. Marušić prepoznaje ketlaške naušnice, među njih pri prvoj objavi ne uvrštava primjerke ovijene žicom iz grobova 43 i 47 te ih datira u širokome vremenskom rasponu od 10. do. 12. stoljeća. ${ }^{20} \mathrm{U}$ kasnijim objavama ipak ih kulturno opredjeljuje i predlaže nešto užu dataciju u 10. - 11. stoljeće. ${ }^{21}$

Ketlaške naušnice u Bosni u razmatranje je uzela N. Miletić. Među tipovima, koje je ona izdvojila kao nakit ketlaške kulture, i primjerci su iz Mahovljana i Župče. ${ }^{22}$ Ova autorica prva upozorava na učestaliju pojavu ovog tipa u Hrvatskoj i Bosni, tražeći mu podrijetlo u radionicama alpskoga kruga i gornjeg Podunavlja. ${ }^{23}$

Nešto sam se opširnije pozabavila spomenutim naušnicama 2009. godine, ukazujući na njihovu široku rasprostranjenost, kao i na mogućnost ranijeg, ali i kasnijega vremenskog opredjeljivanja pojedinih primjeraka. ${ }^{24}$ Također, ustvrdila sam da se unutar ovog tipa pojavljuje više različitih inačica, a kao posebni tip izdvojila sam sva tri para naušnica s Begovače u Biljanima Donjim kojima je donji luk karike, osim spiralnom žicom, ukrašen i nataknutim staklenim zrnom. ${ }^{25}$ Nakon toga, pojavila se i jedna nova inačica, a riječ je o paru naušnica iz groba 33 na Stombratama u Bijaćima kod Trogira. Potonjima je donji luk karike uz spiralno uvijenu žicu ukrašen i kuglastim limenim jagodama. I. Kamenjarin uspoređuje ih s navedenim primjercima sa staklenim zrnima iz grobova na Begovači te pretpostavlja njihovu pripadnost ketlaškoj kulturnoj skupini. ${ }^{26}$

Slične interpretacije pronalazimo i u stranoj literaturi. Naušnice s nekropole Köttlach, kao i primjerak sa Svetih Gorah na Bizeljskem P. Korošec, opredjeljuje kao pilinski tip i pripisuje bjelobrdskome kulturnom krugu. ${ }^{27}$ J. Giesler ih u okviru svoje kronologije za bjelobrdsku kulturu određuje kao tip 18 (sl. 1), a u kontekstu te kulture prema njegovu su mišljenju one tek sporadična pojava. ${ }^{28}$ On se izričito suprotstavlja M. Ćorović Ljubinković, koja ih je smatrala karakterističnima za ketlašku kulturu, ističući da dva donjoaustrijska groblja na kojima su registrirane (Köttlach i Thunau am Kamp) imaju velik udio bjelobrdskog materijala, a i među nalazima s koruškoga groblja Villach - Judendorf Süd, gdje su naušnice tipa 18 registrirane u grobu 26, pojavljuje se nakit bjelobrdske kulture. Unatoč tomu, Giesler posebno izdvaja inačicu kod koje se na donjem luku karike, osim ukrasa u obliku
(Kat. Nr. 8) und Crkvina in Biskupija (Grabfund mit unbekannten Entdeckungsumständen) (Kat. Nr. 4). Ein in Grab 155 in Stenjevec (Zagreb) entdecktes Exemplar (Kat. Nr. 6) stammt aus dem Gebiet Nordkroatiens. In Bosnien und Herzegowina wurde auf dem Gräberfeld Mahovljani-Kužno groblje (Grab 3) (Kat. Nr. 5) ein Ohrring entdeckt, und ein Paar stammt aus Župča (Kat. Nr. 9).

Auf den ersten Blick scheint die größte Konzentration dieser Funde an der kroatischen Küste und ihrem unmittelbaren Hinterland zu liegen, wo die Fundorte, von denen sie herstammen, mit wichtigen Zentren des ersten Kroatischen Fürstentums in Dalmatien in Verbindung gebracht werden können, einschließlich der Fund aus Vinodol. Außerhalb dieses Gebiets treten sie nur sporadisch auf. Bei genauerer Betrachtung aller vorgelegten Funde jedoch, kommen wir zu einem völlig anderen Ergebnis.

Die ältere kroatische archäologische Literatur befasste sich nicht präziser mit diesen Ohrringen. Lj. Karaman schrieb sie, gemeinsam mit einigen anderen Typen, der krantanisch-köttlacher Kultur zu und betrachtete sie als ausländische Importe in das Gebiet Kroatiens. ${ }^{12}$ D. Jelovina schreibt im Allgemeinen über die Ohrringe der Kärnten- und Bijelo Brdo-Kultur, ohne näher auf die Ausarbeitung der bestimmten Typen einzugehen. ${ }^{13}$ Gemäß der in der ausländischen Literatur vorhandenen Terminologie, ordnet er die Ohrringe aus Grab 66 in Mastirine in Kašić dem Piliny-Typ zu (nach den Funden aus Grab 74 am Standort Piliny I in Ungarn). Seiner Meinung nach sind sie charakteristisch für das pannonische Gebiet und stammen aus dem 11. Jahrhundert. ${ }^{14}$ Auch die Schlussfolgerungen von N. Jakšić folgen dieser Annahme. ${ }^{15}$ Den Fund aus Grab 179 in Gorica in Stranče schreibt Ž. Cetinić gleichfalls dem Kulturkreis Bijelo Brdo zu und datiert ihn in das 11. Jahrhundert. ${ }^{16}$ J. Belošević erwähnt 1980 nur beiläufig ein Exemplar aus Grab 93 in Ždrijac in Nin, mit der Feststellung, dass es eine verzierte und nicht vollständig erhaltene Applikation hat. In seinem Text im Jahr 2007 erwähnt er dieses Exemplar überhaupt nicht mehr. ${ }^{17}$ Im Einklang mit anderen kroatischen Autoren schreibt er den Ohrring aus Crkvina in Galovac dem Piliny-Typ zu, der zum Bijelo Brdo-Kulturkreis gehört. ${ }^{18}$ V. Sokol berücksichtigt diesen Typ Ohrringe überhaupt nicht. ${ }^{19}$

Obwohl B. Marušić unter den Schmuckstücken aus Kacavanac in Dvigrad Ohrringe aus der Köttlach-Kultur erkennt, ordnet er ihnen nicht die mit Draht umwundenen Exemplare aus den Gräbern 43 und 47 bei der Erstveröffentlichung zu. Zudem datiert er sie in den weit umfassenden Zeitraum vom 10. bis zum 12. Jahr-

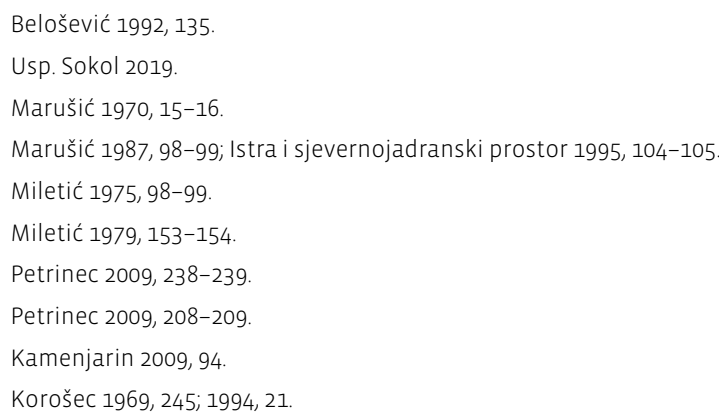

28 Giesler 1981, 126-128.

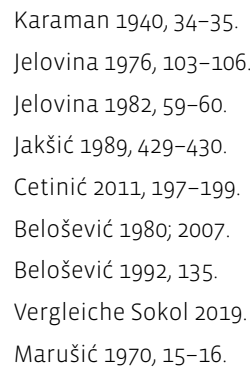


spiralnih vitica, nalaze i tri limene jagode (registriranu na donjoaustrijskim grobljima Zwentendorf i Franzhausen) i pripisuje ju ketlaškoj kulturi s obzirom na to da su te naušnice u oba navedena slučaja otkrivene s nedvojbeno ketlaškim predmetima, poput Iunulastih naušnica ukrašenih emajlom (sl. 2). ${ }^{29}$ Giesler ipak ističe kako pojava tipa 18 nije ograničena samo na bjelobrdsku kulturu, već su ove naušnice prisutne na prostoru cijele jugoistočne Europe, zatim u Slovačkoj i Poljskoj, a jedan usamljeni primjerak potječe iz ranosrednjovjekovnog naselja Petersberg u Baselu u Švicarskoj. ${ }^{30}$ Naušnice su teško opredjeljive u relativno kronološkom smislu jer se na područjima jugoistočne Europe datiraju kasnije nego u okviru bjelobrdske kulture. Za užu dataciju u okviru bjelobrdske kulture, Giesler uzima u obzir nalaze iz groba 26 groblja Székesfehérvár - Radiótelep i groba 258 u Halimbi te zaključuje kako se tip 18 pojavljuje u ranoj (rani dio stupnja I prema njegovoj peridoizaciji), ali također i u najkasnijoj razvojnoj fazi bjelobrdske kulture, a unutar toga razdoblja nije ga moguće čvršće fiksirati.

Na tragu Gieslerovih razmišljanja su i ona S. Eicherta koji se bavio koruškim nalazima. Osim na njihovu pojavu u bjelobrdskom kontekstu, Eichert ukazuje na usporedive primjerke otkrivene u kombinaciji s ketlaškim nalazima. ${ }^{31}$ Ovaj autor predlaže i raniju dataciju u 10. i eventualno u rano 11. stoljeće.

Na naušnice s karikom ukrašenom spiralnim viticama u starijoj srpskoj literaturi osvrnula se S. Ercegović-Pavlović, s obzirom na nalaz iz groba 215 u Mačvanskoj Mitrovici, gdje je jedan primjerak sa završetkom u obliku S-petlje otkriven zajedno sa 7 mađarskih novaca kovanih u rasponu od Kolomana do Geze II (1095. - 1161.), što grob opredjeljuje u sredinu 12. stoljeća. ${ }^{32}$ Na groblju Sellye (grob 46) pak datirane su u nešto ranije razdoblje novcem Ladislava I (1077. - 1095.) ${ }^{33}$ D. Minić pak ističe kako je pojava ovog tipa u Srbiji konstatirana na lokalitetima raspoređenim duž desne ili lijeve obale Dunava, dok su izvan tog pojasa znatno rjeđe. ${ }^{34}$ Uzimajući u obzir prostor republika bivše Jugoslavije, ova autorica zaključuje da su najzastupljenije u okviru starohrvatskih nekropola u Dalmaciji, dok se rjeđe pronalaze u Sloveniji, Bosni i Makedoniji. Naglašava kako je riječ o nakitu s neobično velikim arealom rasprostranjenosti (Rusija, Poljska, Češka, Slovačka, Mađarska, Rumunjska i dalje prema jugu, Bugarska i Grčka). I ona navodi prethodno spominjane grobove datirane mađarskim novcem, pretpostavljajući da je većina srpskih nalaza ipak iz 12. stoljeća, dok se u Bugarskoj i Rumunjskoj nose i u 13. i 14. stoljeću. ${ }^{35}$ Slične naušnice $s$ deltoidnim privjescima u uporabi su još i u 16. stoljeću, o čemu svjedoči jedan grobni nalaz iz Vojlovice u Vojvodini s novcem Ivana Zapolje (1526. - 1540.) i nalaz iz Gaja. ${ }^{36}$ hundert. ${ }^{20}$ In späteren Publikationen bestimmt er sie schließlich in Bezug auf ihre kulturelle Zugehörigkeit und unterbreitet eine etwas genauere Datierung vom 10. bis zum 11. Jahrhundert..1

N. Miletić widmete sich den köttlacher Ohrringen in Bosnien etwas genauer. Zu den Typen, die sie als Schmuck der KöttlachKultur hervorhebt, gehören auch die Exemplare aus Mahovljani und Župča. ${ }^{22}$ Sie ist die erste, die auf das häufigere Auftreten dieses Typs in Kroatien und Bosnien aufmerksam macht, und die seinen Ursprung in den Werkstätten des Alpenraums und des Oberen Donauraums sucht. ${ }^{23}$

Ich selbst habe mich 2009 ausführlicher mit den genannten Ohrringen befasst und auf ihre weite Verbreitung, aber auch auf eine mögliche frühere und spätere Datierung vereinzelter Exemplare hingewiesen. ${ }^{24}$ Ferner habe ich festgestellt, dass mehrere verschiedene Versionen dieses Typs vorkommen. Als einen Sondertypus betrachte ich beispielsweise alle drei Paar Ohrringe aus Begovača in Biljane Donje, deren unterer Ringleinbogen nicht nur mit spiralem Draht, sondern auch mit einer aufgesetzten Glasperle verziert ist. ${ }^{25}$ Danach tritt eine neue Variante in Erscheinung, bei der es sich um ein Paar Ohrringe aus Grab 33 in Stombrate in Bijaći bei Trogir handelt, deren unterer Ringbogen mit spiral gewundenem Draht und kugelförmigen Blechbeeren verziert ist. I. Kamenjarin vergleicht sie mit den oben genannten Ohrringen mit Glasperlen aus den Gräbern in Begovača und geht davon aus, dass sie zur Köttlach-Kulturgruppe gehören. ${ }^{26}$

Ähnliche Auslegungen finden wir auch in der ausländischen Literatur. Ohrringe aus der Nekropole Köttlach sowie ein Exemplar vom Fundort Svete Gore in Bizeljsko (deutsch: Wisell) werden von P. Korošec als Piliny-Typus identifiziert und dem Kulturkreis Bijelo Brdo zugeordnet. ${ }^{27}$ J. Giesler definiert sie im Rahmen seiner Chronologie für die Bijelo Brdo-Kultur als Typ 18 (Abb. 1). Im Kontext dieser Kultur ist ihr Vorkommen seiner Meinung nach nur sporadisch. ${ }^{28}$ Vehement lehnt er die Auffassung von $M$ Corović Ljubinković ab, die die Ohrringe als charakteristisch für die köttlacher Kultur betrachtete und darauf hinwies, dass die beiden niederösterreichischen Gräberfelder, auf denen sie entdeckt wurden (Köttlach und Thunau am Kamp), einen großen Anteil an Bijelo Brdo-Material aufweisen. Aber auch unter den Funden vom Kärntner Gräberfeld Villach-Judendorf Süd findet man Schmuck der Bijelo Brdo-Kultur, wo Ohrringe vom Typ 18 in Grab 26 registriert wurden. Trotzdem hebt Giesler jene Variante hervor, bei der sich im unteren Ringbogen, neben der Verzierung in Form von spiralförmigen Ranken, auch drei Beeren aus Blech befinden (auf den niederösterreichischen Gräberfeldern Zwentendorf und Franzhausen entdeckt). Ihre Zuordnung der
29 Za Franzhausen vidi Aspetsberger, Eichert (2016, 129, sl. 6).

30 Popis nalazišta s naušnicama tipa 18, vidi Giesler (1981, 126-127, bilj. 310), gdje je navedena i literatura u kojoj su publicirane.

31 Eichert 2010, 65; 2013, 425-426.

32 Ercegović-Pavlović 1980, 28, T. XXIII.

33 Kiss 1968,72, sl. 4/46.

34 Минић 1987, 73-75

35 Za popis svih nalaza s područja Srbije i literaturu, vidi Минић (1987, 7375), Ђуровић $(2012,22)$ і Зечевић (2006, 35, kat. 9-11).

36 Минић 1987, 76; Ђуровић 2012, 22-23; Барачки 1977, 17, kat. br. 212.

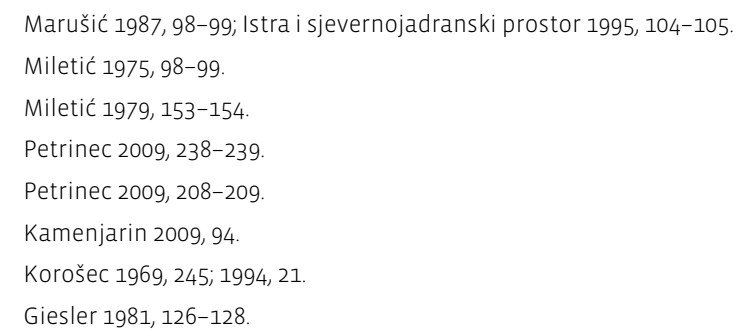




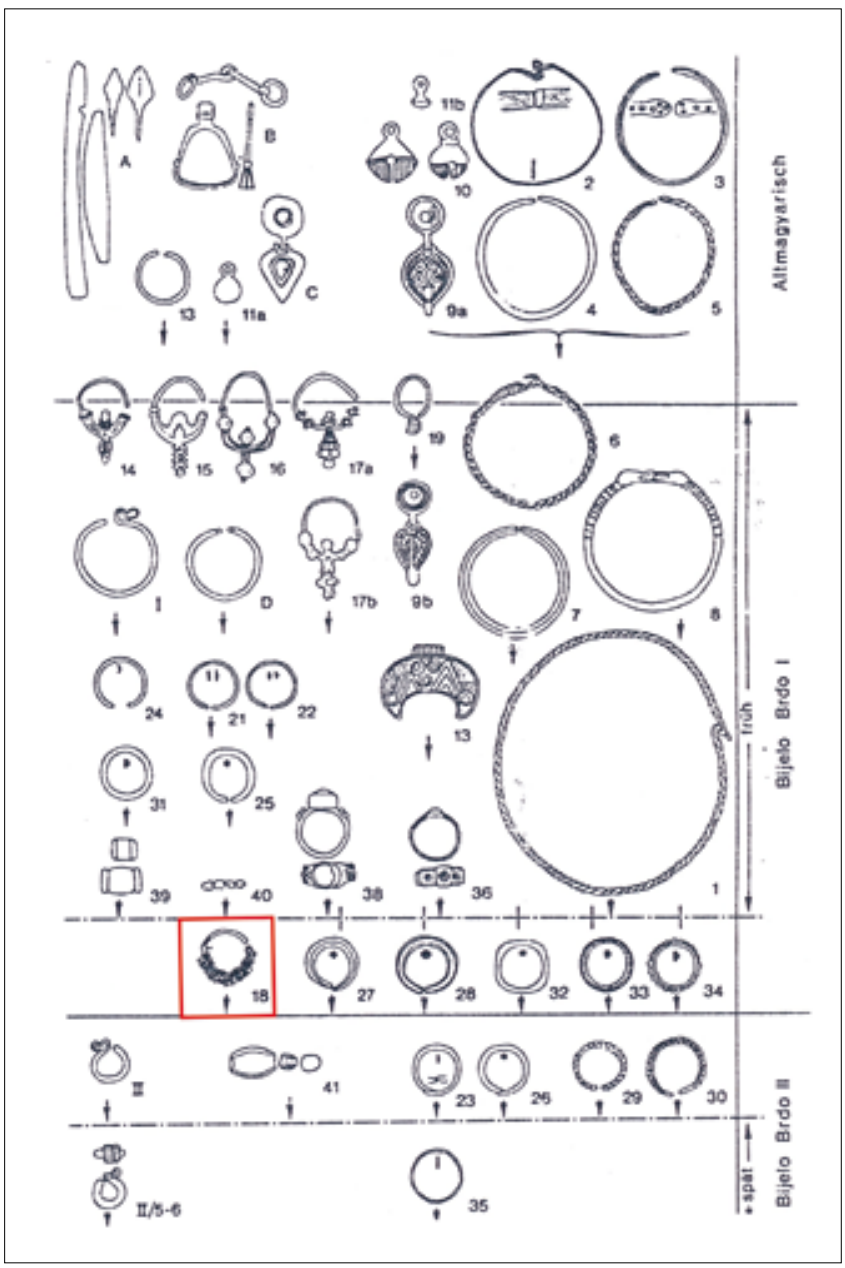

SLIKA 1. Naušnica s donjom polovinom karike, ukrašenom spiralnim viticama, unutar kronologije J. Gieslera za bjelobrdsku kulturu (Giesler 1981).

ABBILDUNG 1. Ohrring, dessen untere Hälfte des Rings mit spiralförmigen Ranken verziert ist, im Rahmen der Chronologie von J. Giesler für die Bijelo BrdoKultur (Giesler 1981).

V. Bikić ukazuje na dugu tradiciju uporabe žice kao samostalnog ukrasa na nakitu koja seže još u 5 . stoljeće prije Krista. ${ }^{37} \mathrm{U}$ rimskom razdoblju na istočnom se Mediteranu pojavljuje nakit načinjen od ovijene ili isprepletene žice koji se može dovesti u vezu s mitom o Herkulu, odnosno s čvorom kao jednim od njegovih atributa. Osim apotropejskog karaktera, važno je istaknuti da je Herkulov čvor i simbol plodnosti, a tako ukrašeni nakit u uporabi je i dugo nakon što se izgubila spoznaja o njegovu izvornom značenju. Bikić vjeruje kako uzore za ovaj tip naušnica treba tražiti u ranobizantskom zlatarstvu. U razdoblju srednjeg vijeka ukras od uvijene žice pojavljuje se prvo na nakitu karantansko-ketlaške kulturne skupine, a potom je od 10. stoljeća prisutan u istočnoj Dalmaciji, kao i na širokom području srednje i istočne Europe. Na središnjem i istočnom dijelu Balkanskog poluotoka nema ga u većem broju prije 12. stoljeća, a u Srbiji je najveći broj nalaza registriran u Podunavlju tijekom 12. 13. i 14. stoljeća. Relativno su brojni primjerci registrirani u rumunjskom dijelu Dobrudže, kao i na pojedinim nalazištima u Bugarskoj u 13. i 14. stoljeću. ${ }^{38}$

37 Bikić 2010, 54-56.

38 Зечевић 2006, 35, bilj. 64.
Köttlach-Kultur basiert er auf der Tatsache, dass die Ohrringe in beiden Fällen mit Gegenständen gefunden wurden, die zweifellos der köttlacher Kultur zuzuschreiben sind, wie beispielsweise mit Halbmondohrringen (siehe Abb. 2). ${ }^{29}$ Giesler weist jedoch darauf hin, dass das Auftreten des Typs 18 nicht auf die Bijelo Brdo-Kultur zu beschränken ist, da diese Ohrringe vielmehr in ganz Südosteuropa zu finden sind, aber auch in der Slowakei und Polen. Ein einzelnes Exemplar stammt aus der frühmittelalterlichen Siedlung Petersberg in Basel, Schweiz. ${ }^{30}$ Die Zuordnung der Ohrringe im chronologischen Sinne ist relativ schwierig, da sie in den südosteuropäischen Gebieten später datiert werden als im Rahmen der Bijelo Brdo-Kultur. Für eine präzisere Datierung innerhalb der Bijelo Brdo-Kultur berücksichtigt Giesler die Funde aus Grab 26 vom Gräberfeld Székesfehérvár - Radiótelep und aus Grab 258 in Halimba und kommt zu dem Schluss, dass Typ 18 in der frühen (frühe Periode der Stufe I gemäß seiner Periodisierung) aber auch in der spätesten Entwicklungsphase der Bijelo Brdo-Kultur auftritt. Innerhalb dieses Zeitraums ist eine genauere Bestimmung jedoch nicht möglich.

Auch die Ansichten von S. Eichert, der sich mit Funden aus Kärnten befasste, folgen mehr oder minder Gieslers Denkweise. Neben ihrem Auftreten im Kontext der Bijelo Brdo-Kultur, verweist Eichert auf vergleichbare Exemplare, die in Kombination mit Köttlach-Funden entdeckt wurden. ${ }^{31}$ Dieser Autor schlägt zudem eine frühere Datierung in das 10. und möglicherweise in das frühe 11. Jahrhundert vor.

In der älteren serbischen Literatur äußerte sich S. Ercegović Pavlović zu den Ohrringen mit spiralförmigen Ranken verzierten Ringlein, und bezog sich dabei auf den Fund aus Grab 215 in Mačvanska Mitrovica, wo ein Exemplar mit S-Schleife am Ende gemeinsam mit 7 ungarischen Münzen entdeckt wurde. Diese Münzen wurden im Zeitraum der Herrschaft von Koloman bis Geza II. (1095-1161) geprägt und datieren somit das Grab in die Mitte des 12. Jahrhunderts. ${ }^{32}$ Auf dem Gräberfeld Sellye (Grab 46) sind sie anhand der Münzen von Ladislaus I. (1077-1095) auf eine etwas frühere Zeit datiert. ${ }^{33} \mathrm{D}$. Minić weist darauf hin, dass dieser Typ in Serbien an Fundorten bemerkt wurde, die entlang des rechten oder linken Ufers der Donau verteilt liegen, während sie außerhalb dieses Gebiets weitaus seltener sind. ${ }^{34}$ Wenn man das Gebiet der ehemaligen jugoslawischen Republiken berücksichtigt, kommt die Autorin zu dem Schluss, dass sie in den altkroatischen Nekropolen in Dalmatien am häufigsten und in Slowenien, Bosnien und Mazedonien weniger verbreitet sind. Ferner weist sie darauf hin, dass es sich um Schmuck handelt, der ein ungewöhnlich weites Ausbreitungsgebiet hat (Russland, Polen, Tschechien, Slowakei, Ungarn, Rumänien und weiter südlich Bulgarien und Griechenland). Auch sie führt die oben genannten und anhand ungarischer Münzen datierten Gräber an, mit der Annahme, dass die meisten serbischen Funde noch aus dem 12.

Für Franzhausen, siehe Aspetsberger, Eichert (2016, 129, Abb. 6) Liste der Fundorte mit Ohrringen des Typs 18, siehe Giesler (1981, 126-127, Anm. 310), wo auch die Literatur angegeben ist, in der sie veröffentlicht sind.

31 Eichert 2010, 65; 2013, 425-426

32 Ercegović-Pavlović 1980, 28, T. XXIII.

33 Kiss 1968, 72, Abb. 4/46.

34 Минић 1987, 73-75. 
U manjem su broju ove naušnice evidentirane i u sjevernoj Makedoniji na lokalitetima u Bitoli, Prilepu i Demir Kapiji, gdje su također datirane u 12. stoljeće. ${ }^{39} \mathrm{U}$ okolici Soluna u Grčkoj pojavljuje se inačica kod koje je karika u donjoj polovini ukrašena trima staklenim zrnima, između kojih se nalazi gusto ovijena žica, a vremenski se opredjeljuju u razdoblje od 10. do 12 . stoljeća $4^{40}$ Još nekoliko srodnih naušnica potječe iz Korinta, gdje su opredijeljene u 11. - 12. stoljeće. ${ }^{41} \mathrm{~J}$. Albani prototip im pronalazi u luksuznim zlatnim filigranskim naušnicama iz Soluna, smatrajući da primjerci sa spiralnom žicom na karici predstavljaju lokalne imitacije bizantskih uzora koji dopiru do dalmatinskog priobalja, a putem hrvatske Posavine (via Bosna i Hercegovina) i do Srbije. Najpopularnije su u 12 . stoljeću. ${ }^{42}$

Uzimajući u obzir sve navedeno, jasno proizlazi da nije riječ o jednoj jedinstvenoj skupini nakita, već o široko rasprostranjenoj pojavi, odnosno o više izrazitih skupina koje su i tipološki i kronološki različite:

1. Prvu veliku skupinu čine naušnice s područja Alpa, gornjeg $i$ srednjeg Podunavlja, Transdanubije i zapadnog dijela savskodravskog međurječja. Pojavljuju se na grobljima s „miješanim“ ketlaškim i ranim bjelobrdskim materijalom i datiraju se u 10. i početak 11. stoljeća.

2. Drugu veliku skupinu predstavljaju naušnice s kasnobjelobrdskih grobalja, u istočnom dijelu Panonije, otkrivene u grobovima i naseobinskim slojevima datiranim novcem mađarskih vladara iz dinastije Arpadovića u kraj 11. i prvu polovinu 12. stoljeća.

3. Treću veliku skupinu predstavljaju naušnice s područja srpskog Podunavlja i pojedinačni primjerci iz ostalog dijela Srbije te pojedinačni primjerci iz sjeverne Makedonije i Grčke datirani u 12. i prva desetljeća 13. stoljeća.

4. Četvrta su velika skupina naušnice 13. i 14. stoljeća u Bugarskoj i Rumunjskoj.

Ako sada pogledamo naušnice iz Hrvatske i Bosne i Hercegovine, treba odmah uočiti da se one ne mogu sve zajedno pripisati samo jednoj od izdvojenih skupina. Kronološki najstarija među njima je ona iz groba 93 na Ždrijacu u Ninu (kat. br. 3). Taj je grob smješten na periferiji zapadne ždrijačke nekropole i, s obzirom na karakter cijeloga groblja, kao i grobove u njegovu okruženju, može se pretpostaviti da pripada ranom odsječku srednjeg vijeka, što dodatno potvrđuje nalaz tzv. šila unutar iste cjeline. ${ }^{43}$ Riječ je o predmetu koji se pojavljuje jedino i isključivo u najstarijem sloju grobova na području na kojem će se tijekom 9. stoljeća formirati hrvatska srednjovjekovna kneževina. Grob 93 može se datirati u 8. ili najkasnije u rano 9. stoljeće. Ždrijački se primjerak naušnice s ukrasom luka u obliku vitica od spiralno uvijene žice ne može, dakle, pripisati ni jednoj od navedenih skupina, od kojih je znatno stariji, i zasad je jedini takav nalaz u ranom horizontu grobova u Dalmaciji.

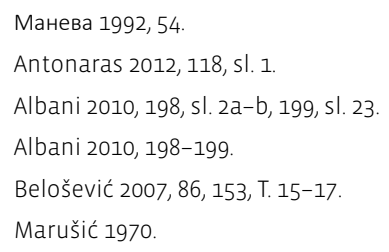

Jahrhundert stammen, während sie in Bulgarien und Rumänien auch im 13. und 14. Jahrhundert getragen wurden. ${ }^{35}$ Ähnliche Ohrringe mit deltaförmigen Anhängern waren auch im 16. Jahrhundert noch in Gebrauch, wie ein Grabfund aus Vojlovica in der Vojvodina mit Münzen von Ivan Zapolje (1526-1540) belegt. ${ }^{36}$

V. Bikić weist auf eine lange Tradition der Verwendung von Draht als eigenständige Dekoration für Schmuck hin, die bereits ins 5. Jahrhundert vor Christus reicht. ${ }^{37}$ In der Römerzeit tritt im östlichen Mittelmeerraum Schmuck aus gewundenem oder geflochtenem Draht in Erscheinung, der mit dem Mythos des Herakles bzw. dem Herakles-Knoten als einem seiner Attribute in Verbindung gebracht werden kann. Dazu ist festzustellen, dass neben seinem apotropäischen Charakter, der Herakles-Knoten auch ein Symbol für Fruchtbarkeit ist. Ein solch dekorierter Schmuck blieb lange in Gebrauch, auch nachdem das Wissen über seine ursprüngliche Bedeutung verloren war. Bikić ist der Ansicht, dass die Vorbilder für diesen Ohrringtyp in der frühbyzantinischen Goldschmiedekunst zu suchen sind. Im Mittelalter erscheinen Verzierungen aus gewundenem Draht seit im Schmuck der Kärnten-Köttlach-Kulturgruppe, während sie ab dem 10. Jahrhundert auch in Ostdalmatien sowie in weiten Teilen Mittel- und Osteuropas präsent sind. Im zentralen und östlichen Teil der Balkanhalbinsel sind sie vor dem 12. Jahrhundert nicht in großer Zahl vorhanden. In Serbien beispielsweise wurde in der Donauniederung die größte Anzahl von Funden festgestellt, die ins 12., 13. und 14. Jahrhundert datieren. Relativ viele Exemplare wurden im rumänischen Teil der Dobrudscha sowie an einigen Orten in Bulgarien registriert, die aus dem 13 und 14. Jahrhundert stammen. ${ }^{38}$

Eine kleine Anzahl dieser Ohrringe wurde in Nordmazedonien an den Standorten Bitola, Prilep und Demir Kapija bemerkt, wo sie ebenfalls ins 12. Jahrhundert datiert wurden. ${ }^{39}$ In der Nähe von Thessaloniki in Griechenland tritt eine Variante in Erscheinung, bei der der Ring in der unteren Hälfte mit drei Glasperlen verziert ist, zwischen denen sich dicht gewundener Draht befindet, und die dem Zeitraum vom 10. bis zum 12. Jahrhundert zugeordnet werden..$^{40}$ Einige weitere verwandte Ohrringe stammen aus Korinth, die ins 11 . bis 12. Jahrhundert datieren..$^{41}$ Einen Prototypen für sie erkennt J. Albani in den luxuriösen filigranen Goldohrringen aus Thessaloniki. Ihrer Meinung nach stellen die Exemplare mit spiralförmigem Draht am Ring lokale Imitationen byzantinischer Muster dar, die bis zur dalmatinischen Küste gelangten und über die kroatische Posavina (über Bosnien und Herzegowina) nach Serbien kamen. Den Höhepunkt ihrer Beliebtheit erreichten sie im 12. Jahrhundert. ${ }^{42}$

35 Für die Liste aller Funde auf dem Gebiet Serbiens und die Literatur, siehe Минић (1987, 73-75), Буровић $(2012,22)$ und зечевић (2006, 35, kat. 9-11).

36 Минић 1987, 76; Ђуровић 2012, 22-23; Барачки 1977, 17, kat. br. 212.

37 Bikić 2010, 54-56

38 Зечевић 2006, 35, Anm. 64

39 Манева 1992, 54.

40 Antonaras 2012, 118, Abb. 1.

41 Albani 2010, 198, Abb. 2a-b, 199, Abb. 23

42 Albani 2010, 198-199. 
Istarske su naušnice otkrivene u okviru kasnoantičko-ranosrednjovjekovnoga groblja kaštela Dvigrad (kat. br. 1a i 1b) unutar kojeg su razmjerno brojne i druge ketlaške naušnice i karičice. ${ }^{44}$ Stoga, ova dva primjerka treba sagledati u tom kontekstu i datirati u 10. ili početak 11. stoljeća, što ih opredjeljuje u prvu prethodno izdvojenu skupinu. Istoj skupini mogu se pribrojiti i naušnice iz groba 179 iz Stranča u Vinodolu (kat. br. 2). Na tom je groblju uočena pojava karičica i naušnica koje se mogu pripisati ketlaškoj kulturi, ali i nakit karakterističan za najraniji stupanj bjelobrdske kulture (naušnice tipa 14 - 16 po Giesleru). Pojava ketlaškog i bjelobrdskog nakita na ovom je groblju sporadična, dok prevladavaju nalazi koji su karakteristični za starohrvatska groblja u Dalmaciji. Ovdje je zanimljivo napomenuti da se grob 179 na Gorici u Stranču uopće ne nalazi u najmlađem južnome dijelu nekropole, gdje je registriran ostali ketlaški i bjelobrdski nakit, već u segmentu sjeveroistočno od najstarijeg središnjega dijela nekropole. Za taj sjeveroistočni dio groblja može se pretpostaviti datacija u kasno 9. i prvu polovinu 10. stoljeća.

Budući da je riječ o nalazu izvan groba, a i s obzirom na činjenicu da groblje nije publicirano pa je i širi kontekst nepoznat, teže je opredjeljiva naušnica s Crkvine u Galovcu (kat. br. 8). Načinom pričvršćivanja ona je srodna istarskim i vinodolskim primjercima, ali je srebrna, što je češći slučaj kod naušnica prethodno izdvojene druge skupine. Dugo trajanje groblja u Galovcu, na kojem se ukapa od 9. do 15. stoljeća, ostavlja mogućnost pripadnosti i prvoj i drugoj skupini naušnica s ukrasom spiralnih vitica na donjem luku karike. Isto vrijedi i za veoma oštećenu naušnicu s Crkvine u Biskupiji (kat. br. 4), kao i za par srebrnih naušnica iz Župče kod Visokog (kat .br. 9) u Bosni i Hercegovini.

S obzirom na završetak u obliku S-petlje, kao i zbog nalaza u okolnim grobovima, naušnice s Mastirina u Kašiću (kat. br. 7) pripadaju ovdje izdvojenoj drugoj skupini i opredjeljuju se u zadnja desetljeća 11. ili u sam početak 12. stoljeća. Istoj skupini pripada i naušnica iz groba 155 u zagrebačkom Stenjevcu (kat. br. 6), otkrivena zajedno s parom tzv. pseudovolinjskih naušnica (Giesler tip 17b), čija je pojava kasnija od ostalih grozdolikih naušnica bjelobrdske kulture i, prema tradicionalnim kronologijama, ulazi u drugu trećinu 11 . stoljeća. 45

Tek fragmentarno sačuvana naušnica iz groba 3 u Mahovljanima (kat. br. 5) otkrivena je u grobu u kojem se, osim nakita ranog stupnja bjelobrdske kulture iz druge polovine 10. i iz prve trećine 11. stoljeća (ogrlica od perlica, probušeni novac, donji dio lijevanoga dvodijelnog privjeska, lijevana naušnica s jagodama, S karičice), pojavljuju i parovi brončanih naušnica s jednom vodoravnom limenom jagodom fiksiranom dvama petljama. Riječ je o jednoj od inačica jagodnih naušnica, čija je masovna pojava zabilježena upravo na grobljima u okolini Prijedora u Mahovljanima i obližnjoj Gomjenici, pa ih se u literaturi i naziva tip Gomjenica / Mahovljani, a starija literatura dovodila ih je u vezu s karantansko-ketlaškom kulturom premda se na području istočnih Alpa pojavljuju veoma rijetko. Ove se naušnice samo sporadično pojavljuju još jedino u Dalmaciji. ${ }^{46}$ Stoga, nalaz iz Mahovljana zasigurno pripada prvoj prethodno izdvojenoj skupini.
Bei der Berücksichtigung all dieser Punkte wird klar, dass es sich nicht um eine einzelne Gruppe von Schmuck handelt, sondern um eine weit verbreitete Erscheinung, bzw. um mehrere ausgeprägte Gruppen, die typologisch und chronologisch unterschiedlich sind:

1. Die erste große Gruppe besteht aus Ohrringen aus der Alpenregion, der oberen und mittleren Donauniederung, Transdanubien und dem westlichen Teil des Zwischenstromgebiets der Save und der Drau. Sie treten auf Gräberfeldern mit gemischtem Material der Köttlach- und der frühen Bijelo Brdo-Kultur auf und werden ins 10. und frühe 11. Jahrhundert datiert.

2. Die zweite große Gruppe repräsentieren Ohrringe von Gräberfeldern der späten Bijelo Brdo-Kultur im östlichen Teil Pannoniens, die in Gräbern und Siedlungschichten entdeckt wurden, die wiederum anhand von Münzen der Arpaden-Dynastie ans Ende des 11. und in die erste Hälfte des 12. Jahrhunderts datiert werden.

3. Die dritte große Gruppe stellen Ohrringe aus dem serbischen Teil der Donauniederung und vereinzelte Exemplare aus dem übrigen Serbien dar, sowie einzelne Exemplare aus Nordmazedonien und Griechenland aus dem 12. und dem ersten Jahrzehnt des 13. Jahrhunderts.

4. Die vierte große Gruppe bilden aus dem 13. und 14. Jahrhundert stammende Ohrringe aus Bulgarien und Rumänien.

Bei näherer Betrachtung der Ohrringe aus Kroatien und Bosnien und Herzegowina, ist unmittelbar festzustellen, dass sie nicht alle gemeinsam nur einer der ausgewählten Gruppen zugeordnet werden können. Chronologisch gesehen ist der Ohrring aus Grab 93 auf Ždrijac in Nin der älteste unter ihnen (Kat. Nr. 3). Dieses Grab befindet sich am Rand der westlichen Nekropole von Ždrijac. Angesichts der Beschaffenheit des gesamten Gräberfeldes, aber auch der Gräber in seinem Umfeld, ist davon auszugehen, dass es zum frühen Teil des Mittelalters gehört, was zusätzlich durch den Fund eines sog. Pfriems innerhalb derselben Grabeinheit bestätigt wird. ${ }^{43}$ Es handelt sich dabei um einen Gegenstand, der einzig und allein in der ältesten Grabschicht in dem Gebiet vorkommt, in dem das mittelalterliche Kroatische Fürstentum im 9. Jahrhundert entsteht. Grab 93 kann ins 8. oder spätestens frühe 9. Jahrhundert datiert werden. Der Ohrring aus Ždrijac, deren Bogen mit Ranken aus spiralförmig gewundenem Draht verziert ist, kann daher keiner der oben genannten Gruppen zugeordnet werden, da er weitaus älter ist und derzeit der einzige derartige Fund aus dem frühen Horizont von Gräbern in Dalmatien ist.

Istrische Ohrringe wurden innerhalb des spätantiken-frühmittelalterlichen Gräberfelds der Burg Dvigrad (Kat. Nr. 1a und 1b) entdeckt, auf dem auch verhältnismäßig viele andere KöttlachOhrringe und Ringe gefunden wurden. ${ }^{44}$ Demzufolge sollten diese beiden Exemplare in diesem Kontext betrachtet und ins 10. oder frühe 11. Jahrhundert datiert werden, was sie in die oben genannte erste Gruppe zuordnet. Derselben Gruppe kann man auch die Ohrringe aus Grab 179 aus Stranče in Vinodol hinzu(2016)

46
O pseudovolinjskim naušnicama (Giesler tip 17b) opširnije, vidi i Kefelja

Vidi Petrinec 2009, 225-226.
Belošević 2007, 86, 153, T. 15-17.

Marušić 1970 


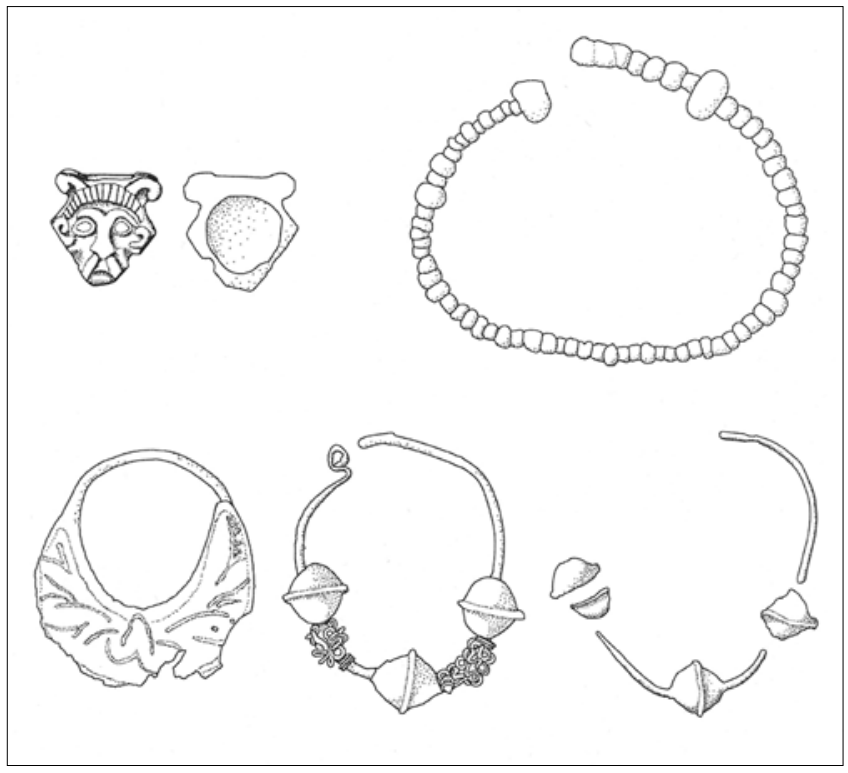

SLIKA 2. Grob 1 iz Franzhausena u Donjoj Austriji (Aspetsberger, Eichert 2016). ABBiLdUNG 2. Grab 1 aus Franzhausen in Niederösterreich (Aspetsberger, Eichert 2016).

Preostaju još tri para naušnica, koje u donjoj polovini karike, osim ukrasa u obliku spiralnih vitica, imaju nataknuta staklena zrna, odnosno limene jagode.

Par brončanih naušnica iz groba 33 na Stombratama u Bijaćima (kat. br. 11) veoma je oštećen te ostaje nepoznato jesu li imale samo jednu ili možda tri jagode. Jedini usporedivi primjerci zasad su registrirani u ketlaškom miljeu na dva donjoaustrijska groblja. Grob 68 u Zwentendorfu može se na osnovu nalaza novca u grobu 113 na istom nalazištu datirati u razdoblje između 967. i 999. godine. U grobu 1 u Franzhausenu ovaj tip naušnice dolazi zajedno s lunulastom ketlaškom naušnicom te se može vremenski opredijeliti u 10. stoljeće (sl. 2).47

Groblje u Bijaćima također vremenski pripada kasnijem 9. i 10. stoljeću, a osim naušnica iz groba 33, ovdje se u dva groba pojavljuju i naušnice s petljama i provješenim lančićima od spiralno uvijene žice, koje su se u starijoj literaturi također dovodile u vezu s istočnoalpskim prostorom. ${ }^{48}$

Tri para iz Begovače (kat. br. 10a-c) mogu se pak povezati s nakitom ukrašenim nataknutim staklenim perlama. Dodavanje staklenih perli karičicama ili naušnicama veoma je popularno na prostoru istočnih Alpa u okviru pretketlaškog i ketlaškog horizonta, a zabilježeno je i na istarskom groblju na Kacavancu u Dvigradu, u jednom slučaju upravo u grobu s naušnicom ukrašenom spiralnim viticama. Međutim, taj je običaj ukrašavanja prisutan i na bjelobrdskim grobljima, kao i na grobljima s „miješanim inventarom" u sjeverozapadnoj Bosni, a u nekoliko slučajeva i u Dalmaciji, gdje nataknuta perla predstavlja samostalni ukras na fügen (Kat. Nr. 2). Auf diesem Gräberfeld verzeichnete man das Auftreten von Ringlein und Ohrringen, die der Köttlach-Kultur zugeschrieben werden, aber auch Schmuck, der für die früheste Stufe der Bijelo Brdo-Kultur charakteristisch ist (Ohrringe Typ 14-16 nach Giesler). Das Vorkommen von Schmuck der Köttlachund Bijelo Brdo-Kultur auf diesem Gräberfeld ist sporadisch, während die für die altkroatischen Gräberfelder in Dalmatien charakteristischen Funde überwiegen. Interessanterweise befindet sich Grab 179 auf Gorica in Stranče nicht im jüngsten südlichen Teil der Nekropole, wo andere Köttlach- und Bijelo Brdo-Schmuckstücke entdeckt wurden, sondern im Bereich nordöstlich vom ältesten zentralen Teil der Nekropole. Für diesen nordöstlichen Teil des Gräberfelds wird eine Datierung ins späte 9 . und die erste Hälfte des 10. Jahrhunderts angenommen.

Die Zuordnung des Ohrrings aus Crkvina in Galovac ist weitaus schwieriger, da es sich um einen Fund außerhalb des Grabes handelt, aber auch aufgrund der Tatsache, dass das Gräberfeld nicht veröffentlicht wurde und demnach ein weitergefasster Kontext nicht bekannt ist (Kat. Nr. 8). Ihre Befestigungsweise ähnelt jenen Exemplaren aus Istrien und Vinodol, doch handelt es sich hierbei um ein Exemplar aus Silber, was häufiger der Fall ist bei den Ohrringen aus der oben genannten zweiten Gruppe. Das lange Bestehen des Gräberfeldes in Galovac, wo Bestattungen vom 9. bis zum 15 . Jahrhundert stattfanden, ermöglicht die Zuordnung sowohl in die erste als auch zweite Gruppe von Ohrringen, deren unterer Ringbogen mit spiralförmigen Ranken verziert ist. Gleiches gilt auch für einen stark beschädigten Ohrring aus Crkvina in Biskupija (Kat. Nr. 4) sowie für ein Paar Silberohrringe aus Župča bei Visoko (Kat. Nr. 9) in Bosnien und Herzegowina.

Mit Hinblick auf das Ende in Form einer S-Schleife sowie aufgrund der Funde in den umliegenden Gräbern gehören die Ohrringe aus Mastirine in Kašić (Kat. Nr. 7) zur hier genannten zweiten Gruppe und werden den letzten Jahrzehnten des 11. oder dem Anfang des 12. Jahrhunderts zugeschrieben. Zur gleichen Gruppe gehört auch der Ohrring aus Grab 155 in Stenjevec (Kat Nr. 6), der zusammen mit einem Paar Ohrringe des sogenannten Pseudo- Volhynien-Typs (Giesler Typ 17b) entdeckt wurde, der später als die anderen traubenförmigen Ohrringe der Bijelo Brdo-Kultur auftritt und, gemäß traditionellen Zeitrechnungen, in das zweite Drittel des 11. Jahrhunderts datiert. ${ }^{45}$

Der in Fragmenten erhaltene Ohrring aus Grab 3 in Mahovljani (Kat. Nr. 5) wurde in einem Grab entdeckt, in dem außer Schmuck der frühen Stufe der Bijelo Brdo-Kultur aus der zweiten Hälfte des 10. und dem ersten Drittel des 11 . Jahrhunderts (Perlenkette, durchbrochene Münze, der untere Teil eines gegossenen zweiteiligen Anhängers, ein gegossener Ohrring mit Beeren, Schläfenring mit S-Schleife), auch Paare von Bronzeohrringen mit einer waagrechten und zwei Schleifen fixierten Beere aus Blech gefunden wurden. Es handelt sich dabei um eine der Ohrringvarianten mit Beeren, deren massenweises Auftreten auf den Gräberfeldern um Prijedor in Mahovljani und in der Nähe 
karici. ${ }^{99}$ Primjerci iz Begovače nemaju izravnih analogija, a najsličnije su im već spominjane naušnice iz okolice Soluna datirane od 10. do 12. stoljeće. U 10. - 11. stoljeća datiraju se naušnice s nataknutim staklenim zrnima u Makedoniji. ${ }^{50}$

\section{Naušnice s privjeskom od spiralno uvijene žice}

Na području današnje Hrvatske i Bosne i Hercegovine registrirano je dosad ukupno 26 primjerka (kat. br. 12-22; Karta 2). Od toga su 22 grobni nalazi, otkriveni u okviru sustavnih arheoloških iskopavanja, a dvije su nepoznatih okolnosti otkrića, no može se pretpostaviti da također potječu iz grobova. Jedna je naušnica naseobinski nalaz. Sve su načinjene od brončane žice. Šest ih je otkriveno u paru; u jednom grobu u Bijelom Brdu (ul. Venecija) bila su tri primjerka, dok su ostale pojedinačni primjerci unutar grobova. Većina ih ima spiralni privjesak proširen prema dolje (naušnica iz groba 161 u Privlaci, naušnice iz Vukovara i Osijeka, dio naušnica iz Bijelog Brda, naušnica s Gorice u Stranču, naušnica iz groba 162 uz Crkvu sv. Križa u Ninu i naušnica iz Bijaća). Dio naušnica iz Bijelog Brda te naušnice iz Petoševaca, Plavna, Prečnog pola 1 i groba 14 u Privlaci imaju privjesak kod kojeg je spiralni navoj jednake širine. Kod naušnice iz groba 89 uz Crkvu sv. Križa u Ninu privjesak nije u potpunosti sačuvan pa mu se ne može odrediti oblik.

S obzirom na mali broj nalaza u Hrvatskoj, starija domaća arheološka literatura nije se opsežnije bavila ovim naušnicama. Prvi se na njih kratko osvrnuo Z. Vinski 1952. godine vezano uz nalaz na zagrebačkom Kaptolu (kat. br. 14). ${ }^{51}$ Smatrao je da je riječ o rijetkom primjerku slavenskog nakita kojemu analogiju pronalazi u jednoj naušnici s lokaliteta Keszthely. Ukazuje i na nalaze iz Bijelog Brda, gdje je otkriveno nekoliko naušnica istog tipa u dvije inačice; sa stožastim i s valjkastim nastavkom te na nalaze iz Bogojeva i Novih Banovaca u Vojvodini i Ptuja u Sloveniji. Smatra ih starijima od glavnine materijala bjelobrdske kulture, što, prema njemu, potvrđuju i nalazi iz kasnoavarodobne nekropole Děvínská Nová Ves, kao i nalazi s miješane kasnoavarodobno-ketlaške nekropole Hohenberg. Zaključuje da predstavljaju prijelazni oblik iz kasnoavarodobne kulture u bjelobrdsku kulturu.

J. Korošec posvetio je ovim naušnicama čitav jedan članak. ${ }^{52} \mathrm{Na}$ tragu razmišljanja Z. Vinskog, i on također prvo razlikuje dvije skupine naušnica sa spiralnim privjeskom, ali smatra da s tipološkoga gledišta nije posebno vjerojatan prijelaz iz jednog tipa (kasnoavarskog) u drugi (bjelobrdski) s obzirom na njihovu suviše veliku međusobnu razliku. Što se tiče starije skupine, Korošec upozorava i na nalaze iz Albanije sa spiralnim privjeskom u obliku svrdla za koje također pretpostavlja da pripadaju kasnoavarskoj skupini. Ta bi skupina, prema njemu, imala dva centra rasprostranjenosti; jedan, sjeverno od Drave između Blatnog jezera i Dunava, i drugi, u okolini Skadra. Mlađe naušnice razli- von Gomjenica beobachtet wurde. In der Literatur werden sie daher als Typ Gomjenica/Mahovljani bezeichnet. In der älteren Literatur wurden sie in Verbindung mit der karantanisch-kötllacher Kultur gebracht, aber in Ostalpenraum kommen sie sehr selten vor. Diese Ohrringe kommen sporadisch nur noch in Dalmatien vor. ${ }^{46}$ Daher gehört der Fund aus Mahovljani sicherlich zur oben angeführten ersten Gruppe.

Übrig bleiben nur noch drei Paar Ohrringe, die in der unteren Hälfte des Rings neben einer Verzierung aus spiralförmigen Ranken auch einer aufgesetzten Glasperle bzw. Blechbeeren aufweisen.

Ein Paar Bronzeohrringe aus Grab 33 in Stombrate in Bijaći (Kat. $\mathrm{Nr} .11$ ) ist stark beschädigt, daher ist nicht genau bekannt, ob es nur eine oder vielleicht drei Beeren ursprünglich hatte. Die einzigen vergleichbaren Exemplare wurden bisher im KöttlachUmfeld auf zwei niederösterreichischen Gräberfeldern registriert. Grab 68 in Zwentendorf kann anhand von Münzfunden in Grab 113 am gleichen Fundort auf den Zeitraum zwischen 967 und 999 datiert werden. Diesen Typ von Ohrring entdeckte man gemeinsam mit einem lunularen Köttlach-Ohrring in Grab 1 in Franzhausen, er ist ins 10. Jahrhundert zu datieren (Abb. 2). ${ }^{47}$

Das Gräberfeld in Bijaći stammt ebenfalls aus dem späten 9. und 10. Jahrhundert. Außer den Ohrringen aus Grab 33, entdeckte man an diesem Fundort Ohrringe mit Schleifen und durchgezogenen Kettchen aus spiralförmig gewundenem Draht in zwei Gräbern, die in der älteren Literatur auch mit dem östlichen Alpenraum in Verbindung gebracht wurden. ${ }^{48}$

Drei Paare aus Begovača (Kat. Nr. 10a-c) können mit Schmuck verbunden werden, der mit aufgesetzten Glasperlen verziert ist. Das Beifügen von Glasperlen zu Ringlein oder Ohrringen war im Ostalpenraum innerhalb des der Vor-Köttlach Horizont und Köttlach-Kultur sehr beliebt. Derartige Exemplare wurden auch auf dem istrischen Gräberfeld in Kacavanac in Dvigrad registriert, wo sie in einem Fall in einem Grab mit einem Ohrring entdeckt wurden, der mit spiralförmigen Ranken verziert ist. Dieser Verzierungsbrauch findet sich jedoch auch auf Gräberfeldern der Bijelo Brdo-Kultur, sowie auf Gräberfeldern mit "gemischtem Inventar“ im nordwestlichen Bosnien und in mehreren Fällen in Dalmatien, wo eine aufgesetzte Perle eine eigenständige Verzierung auf dem Ring darstellt. ${ }^{49}$ Die Exemplare aus Begovača haben keine direkten Analogien, und die ihnen am ähnlichsten sind die bereits erwähnten Exemplare aus der Region Thessaloniki, die in den Zeitraum vom 10. bis 12. Jahrhundert datieren. Ohrringe mit aufgesetzten Glasperlen in Mazedonien stammen aus dem 10.-11. Jahrhundert.50

\footnotetext{
49 Petrinec 2009, 207-208. Opširnije o grobljima sjeverozapadne Bosne s „miješanim inventarom“, vidi (Šmalcelj 2012).

50 Манева 1992, 46-47, Т. 19

51 Vinski 1952, 30, 51-52.

52 Korošec 1957, 175-180.

53 Jelovina 1976, 103-106
}

\footnotetext{
$46 \quad$ Siehe Petrinec 2009, 225-226.

47 Aspetsberger, Eichert 2016, 128-129.

48 Vergleiche Kamenjarin 2009, 90, 104, T. VII, 3-4; 91, 106, T. X, 4-5.

49 Petrinec 2009, 207-208. Für ausführlichere Informationen zu den Gräberfeldern im nordwestlichen Bosnien mit „gemischtem Inventar“, siehe (Šmalcelj 2012).

50 Манева 1992, 46-47, Т. 19.
} 


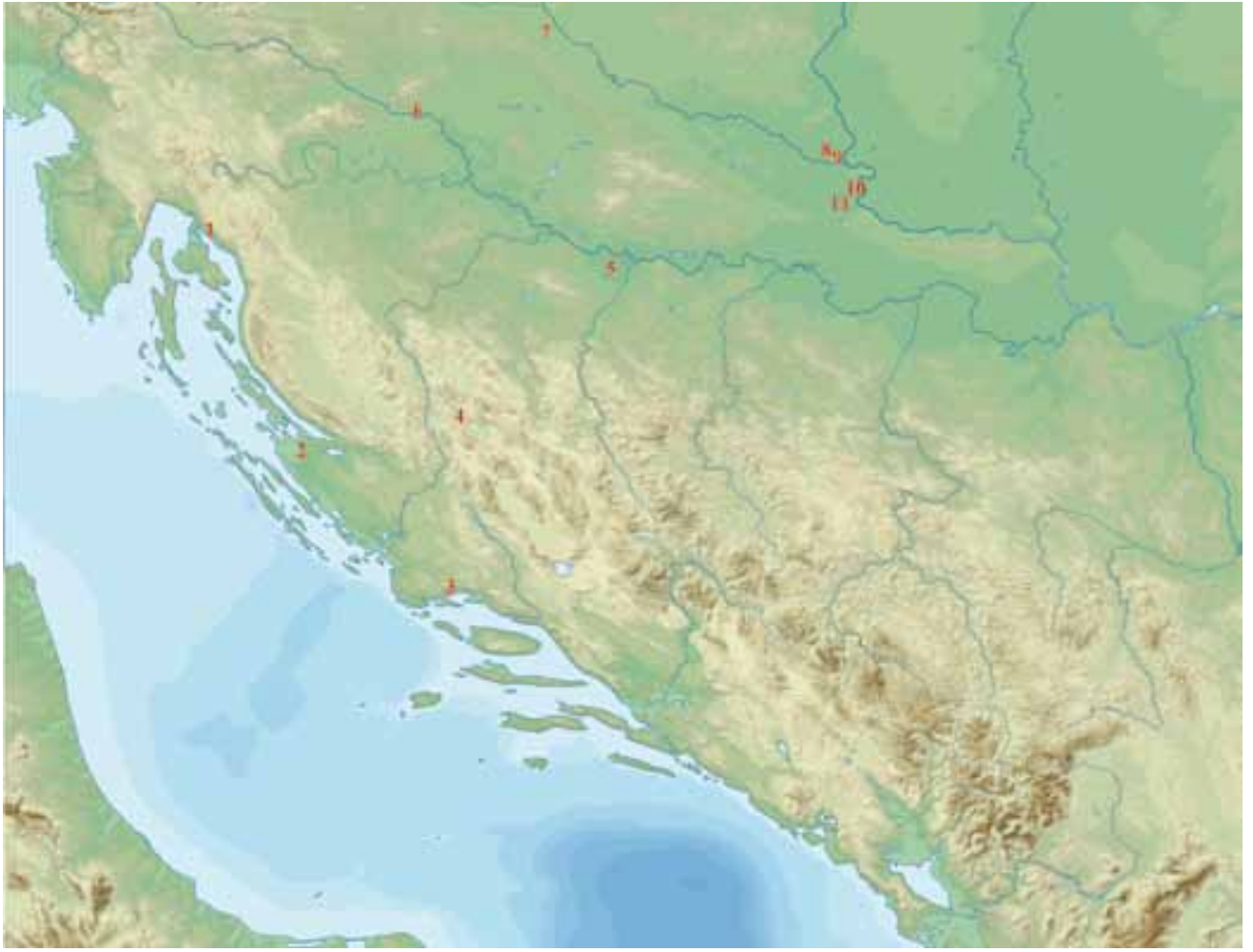

KARTA 2. Naušnice s ukrasom u obliku spiralnog stošca:

1 - Stranče, 2 - Nin, 3 - Bijaći, 4 Plavno, 5 - Petoševci, 6 - Zagreb, 7 - Torčec, 8 - Osijek, 9 - Bijelo Brdo, 10 - Vukovar, 11 - Privlaka (izradila M. Petrinec).

KARTE 2. Ohrringe mit Verzierung in Form eines spiralförmigen Kegels:

1-Stranče, 2-Nin, 3-Bijaći, 4-Plavno, 5-Petoševci, 6-Zagreb, 7-Torčec, 8-Osijek, 9-Bijelo Brdo, 10-Vukovar, 11-Privlaka (hergestellt von $\mathrm{M}$ Petrinec).

kuju se od prijašnjih po privjesku koji je koničan ili cilindričan, a pojavljuju se u izrazito bjelobrdskim grobnim cjelinama. Korošec izričito odbacuje povezanost ovog tipa s ketlaškom skupinom, a dovodi u pitanje i njegovu pojavu u kasnoavarskom miljeu.

D. Jelovina 1976. naušnicu iz Plavnog (kat. br. 19), koja je tada bila jedini poznati takav nalaz u Dalmaciji, pripisuje karantansko-ketlaškoj kulturi. ${ }^{53}$

Za brončanu naušnicu sa spiralnim ukrasom iz groba 89 uz Crkvu sv. Križa u Ninu (kat. br. 17a) J. Belošević navodi tek kako nema analogija. ${ }^{54}$ Prema ostalome grobnom inventaru, grob 89 pripisan je drugom sloju ukapanja koji se vremenski opredjeljuje u 10. - 11. stoljeće. Grob 162, koji sadržava jednu brončanu naušnicu sa spiralnim privjeskom (kat. br. 17b), Belošević svrstava u najstariji sloj pokapanja na tom groblju i uspoređuje ju sa srodnim naušnicama otkrivenima na slovačkoj avarodobnoj nekropli Nové Zámky, gdje su datirane u rasponu od 700. do 825 . godine. ${ }^{55} \mathrm{Na}$ osnovu navedenih analogija, grob 162 datira u 8. stoljeće..$^{56}$

U vezi s nalazom iz groba 5, na Gorici u Stranču (kat. br. 16), Ž. Cetinić napominje kako se dio naušnica s privjeskom u obliku spiralnog stošca vezuje uz repertoar bjelobrdske kulture, a dio pripisuje karantansko-ketlaškoj kulturi.57

\footnotetext{
54 Belošević 1998, 140-142.

55 Belošević 1998, 148.

56 Belošević cijeli taj sloj grobova datira u 7. i 8. stoljeće i pripisuje kasnoantičkom stanovništvu. Međutim, nalazi ovog sloja ne odudaraju od ostalih na laza najstarijeg horizonta ranosrednjovjekovnih grobalja u Dalmaciji, što potvrđuju i kasnija istraživanja obližnjih grobova na Banovcu vidi kod Radović (2010, 166-167) i Dadić (2020, 364, 377-379) koji su dio istoga groblja i istog ukopnog sloja. Vidi i Petrinec $(2019,85)$.

57 Cetinić 2011, 199.
}

\section{Ohrringe mit Anhänger aus spiral gewundenem Draht}

Im heutigen Kroatien sowie in Bosnien und Herzegowina wurden bisher insgesamt 26 Exemplare registriert (Kat. Nr. 12-22; Karte 2), wovon 22 Grabfunde sind, die im Rahmen von systematisch durchgeführten archäologischen Ausgrabungen entdeckt wurden. Bei zwei Exemplaren sind die Fundsumstände unbekannt, jedoch ist davon auszugehen, dass auch sie aus Gräbern stammen. Ein Ohrring ist ein Siedlungsfund. Alle Ohrringe sind aus Bronzedraht hergestellt. Sechs wurden als Ohrringpar entdeckt. Drei Exemplare fand man in einem Grab in Bijelo Brdo (Straße Venedig), während die anderen einzelne Exemplare in Gräbern waren. Die meisten von ihnen haben einen nach unten erweiterten spiralen Anhänger (Ohrring aus Grab 161 in Privlaka, Ohrringe aus Vukovar und Osijek, Teile von Ohrringen aus Bijelo Brdo, Ohrring aus Gorica in Stranče, Ohrring aus Grab 162 neben der Kirche des Heiligen Kreuzes in Nin und Ohrring aus Bijaći). Ein Teil der Ohrringe aus Bijelo Brdo sowie die Ohrringe aus Petoševci, Plavno, Prečno Pole 1 und Grab 14 in Privlaka haben einen Anhänger mit einem gleichbreiten spiralen Gewinde. Bei dem Ohrring aus Grab 89 neben der Kirche des Heiligen Kreuzes in Nin ist der Anhänger nicht vollständig erhalten, so dass seine Form nicht bestimmbar ist.

Angesichts der geringen Anzahl von Funden in Kroatien befasste sich die ältere kroatische archäologische Literatur nicht ausführlicher mit diesen Ohrringen. Z. Vinski äußerte sich 1952 als erster kurz zu den Funden auf dem Kaptol in Zagreb (Kat. Nr. 14). ${ }^{51} \mathrm{Er}$ betrachtete sie als ein seltenes Beispiel für slawischen

\footnotetext{
51 Vinski 1952, 30, 51-52.
} 
I. Kamenjarin pak vjeruje da se, s obzirom na dužinu stožastog privjeska od spiralne žice, naušnica iz groba 30 u Stombratama (kat. br. 18) ne može pripisati bjelobrdskoj kulturi, a vremenski je opredjeljuje oko sredine 9 . stoljeća. ${ }^{58}$

Naseobinski nalaz iz Prečnog pola I (kat. br. 13) opredijeljen je u razdoblje od kraja 8 . do sredine 9. stoljeća. ${ }^{59}$

Sama sam se 2009. godine kraće osvrnula na nalaze iz Dalmacije te upozorila na široku rasprostranjenost srodnih naušnica u srednjoj i jugoistočnoj Europi, kao i na njihovu različitu kulturnu pripadnost i raznoliko datiranje. ${ }^{60}$ Tada sam dalmatinske primjerke paušalno opredijelila oko sredine 9 . stoljeća. ${ }^{61}$

U novijoj su hrvatskoj arheološkoj literaturi naušnice sa spiralnim privjeskom opsežnije razmatrali Ž. Demo i V. Sokol.

Demo ističe kako je riječ o sporadičnoj pojavi unutar bjelobrdskoga kulturnog kruga, gdje naušnice sa spiralnim privjeskom nisu mnogo više od reminiscencije na slične nakitne oblike začete u avaro-slavenskom krugu kasnog 8 . i s početka 9. stoljeća ${ }^{62}$ Proširene su među stanovnicima karolinškog razdoblja u istočnoj Austriji i zapadnoj Mađarskoj tijekom 9. i početkom 10. stoljeća. Bjelobrdske naušnice sa spiralnim privjeskom Demo dijeli u više inačica: najučestalije su one s prema dolje proširenim privjeskom, nešto rjeđe naušnice s cilindričnim privjeskom, a samo je jedan primjerak s prema dolje suženim završetkom. Karakteristične su za grobove djevojčica, a samo ponekad dolaze i u grobovima odraslih žena. U okvirima bjelobrdske kulture pojava ovih naušnica pada u prijelaz 10. na 11. stoljeće, najintenzivnija uporaba im je u prvoj četvrtini ili prvoj trećini 11. stoljeća, a krajnji datum nakon kojeg izlaze iz mode je sredina 11. stoljeća. Prema Demi, jedno od proizvodnih središta ovih naušnica nalazilo se u južnoslavenskim krajevima uz donji tok rijeke Drave.

V. Sokol osvrće se samo na nalaze starije od naušnica bjelobrdske kulture; smatra da se primjerci iz Zagreba i Plavnog ne mogu pobliže opredijeliti zbog nejasnih okolnosti otkrića, a vinodolski primjerak i naušnicu iz Stombrata smješta u sredinu 9. stoljeća, naušnice iz Petoševaca u Bosni i Prečnog pola I u Podravini u drugu polovinu 9. ili prvu polovinu 10. stoljeća, dok se, prema njegovu mišljenju, primjerci poput onog iz groba 162 uz Crkvu sv. Križa u Ninu mogu datirati tijekom cijelog 9. stoljeća. ${ }^{63}$

\footnotetext{
58 Kamenjarin 2009, 95

59 Sekelj Ivančan 2010, 140-141, 257, T. 37, 230.

60 Za kasnoavarske nalaze, vidi Čilinská (1975, 76-77); za srednjoeuropske nalaze, vidi Szőke (1992, 118-120); za nalaze u ranomađarskim grobovima, vidi Szőke (1962, 39-41); za nalaze u bjelobrdskom kontekstu, vidi Giesler (1981, 129, bilj. 319); za makedonske i albanske nalaze, vidi Манева (1992, 44-45) і Вукосављевић $(2012,22)$.

61 Petrinec 2009, 206-207

62 Demo 2009, 449-452. Na str. 449-450 je i cjelovit popis literature koja se bavila ovim naušnicama, kao i karta bjelobrdskh grobalja na kojima su pronađene.

63 Sokol 2019, 213-216
}

Schmuck, dem er eine Analogie im Ohrring aus Keszthely fand. Zudem verwies er auch auf die Funde aus Bijelo Brdo, wo mehrere Ohrringe des gleichen Typs in zwei Varianten entdeckt wurden (mit kegelförmigem und mit walzenförmigem Zusatz), sowie auf Funde aus Bogojevo und Novi Banovci in der Vojvodina und Ptuj in Slowenien. Seiner Ansicht nach waren sie älter als die Mehrheit des Materials der Bijelo Brdo-Kultur, was seiner Meinung nach auch die Funde von der spätawarischen Nekropole Děvínská Nová Ves sowie Funde von der gemischten „spätawarischen-köttlacher" Nekropole Hohenberg bestätigen. Er kam zu dem Schluss, dass sie eine Übergangsform aus der spätawarischen Kultur in die Bijelo Brdo-Kultur darstellen.

J. Korošec widmete diesen Ohrringen einen ganzen Artikel.52 Den Ansichten von Z. Vinski folgend, unterscheidet auch er zunächst zwei Gruppen von Ohrringen mit spiralförmigem Anhänger. Jedoch ist er der Ansicht, dass, aus typologischer Sicht, der Übergang von einem Typ (spätawarisch) in einen anderen (Bijelo Brdo) nicht sehr wahrscheinlich ist aufgrund ihres zu großen Unterschieds zueinander. In Bezug auf die ältere Gruppe deutet Korošec auch auf die Funde aus Albanien mit einem spiralen Anhänger in Form eines Bohrers, von denen er annimmt, dass sie zur spätawarischen Gruppe gehören. Ihm zufolge würde diese Gruppe zwei Ausbreitungszentren haben; eines nördlich der Drau zwischen dem Plattensee und der Donau und das andere in der Nähe von Shkodra. Jüngere Ohrringe unterscheiden sich von den vorherigen durch einen kegelförmigen oder zylindrischen Anhänger und treten in Grabeinheiten auf, die besonders die Bijelo Brdo-Kultur reflektieren. Korošec lehnt eine Verbindung zwischen diesem Typ und der Köttlach-Gruppe ausdrücklich ab und stellt auch ihr Auftreten im spätawarischen Umfeld in Frage.

D. Jelovina schreibt 1976 den Ohrring aus Plavno (Kat. Nr. 19), der zu dieser Zeit der einzige bekannte Fund in Dalmatien war, der Kärnten-Köttlach-Kultur zu. ${ }^{53}$

J. Belošević gibt lediglich an, dass keine Analogien für den Bronzeohrring mit spiraler Verzierung aus Grab 89 neben der Kirche des Heiligen Kreuzes in Nin (Kat. Nr. 17a) zu finden sind. ${ }^{54}$ Anhand des übrigen Grabinventars wird Grab 89 der zweiten Bestattungsschicht zugeordnet, die zwischen dem 10. und 11. Jahrhundert stattfand. Grab 162, das einen Bronzeohrring mit einem spiralen Anhänger (Kat. Nr. 17b) enthielt, ordnet Belošević der ältesten Bestattungsschicht auf diesem Gräberfeld zu und vergleicht ihn mit verwandten Ohrringen, die in der slowakischen awarenzeitlichen Nekropole Nové Zámky entdeckt wurden, wo sie in die Zeit von 700 bis 825 datieren. ${ }^{55}$ Anhand der oben genannten Analogien wird Grab 162 ins 8. Jahrhundert datiert. ${ }^{6}$

\footnotetext{
52 Korošec 1957, 175-180.

53 Jelovina 1976, 103-106.

54 Belošević 1998, 140-142.

55 Belošević 1998, 148

56 Belošević datiert diese gesamte Schicht von Gräbern ins 7. und 8. Jahrhundert und schreibt sie der spätantiken Bevölkerung zu. Die Funde aus dieser Schicht unterscheiden sich jedoch nicht von anderen Funden aus dem ältesten Horizont frühmittelalterlicher Gräberfelder in Dalmatien, was auch spätere Ausgrabungen nahegelegener Gräber in Banovac bestätigen, siehe Radović (2010, 166-167) und Dadić (2020, 364, 377-379) die Teil desselben Gräberfeldes und derselben Bestattungsschicht sind. Siehe auch Petrinec $(2019,85)$
} 


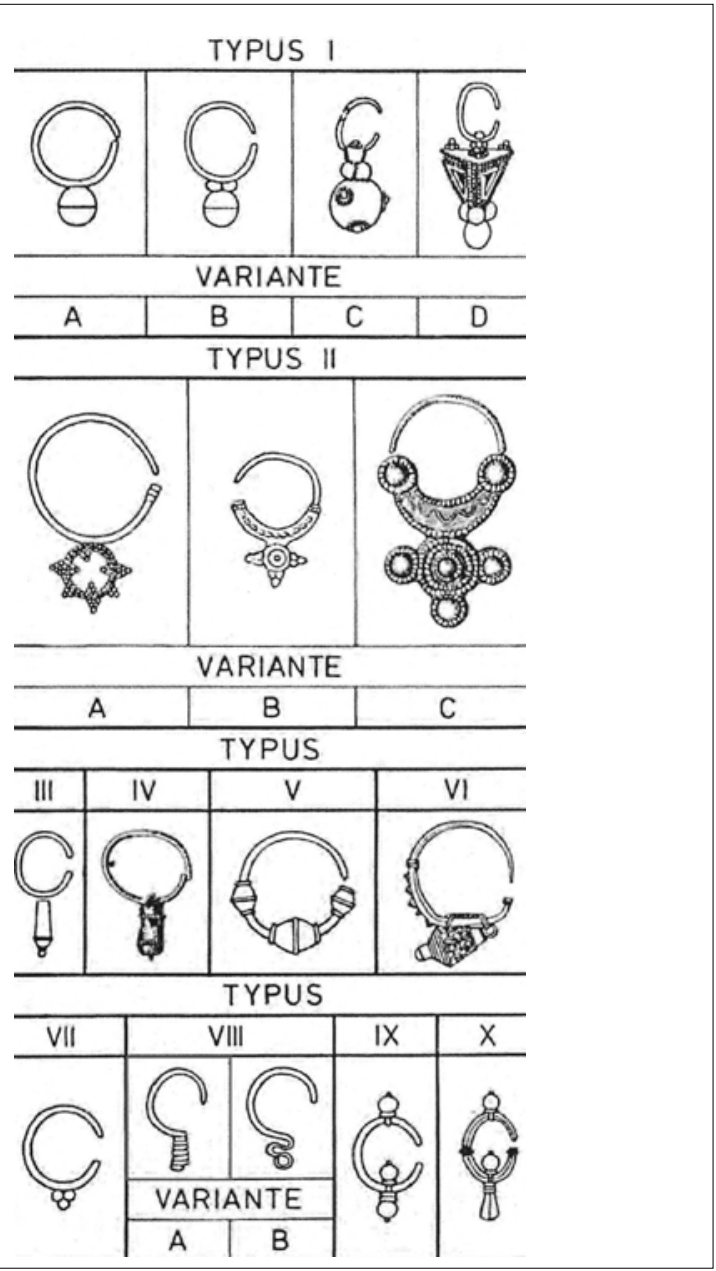

SLIKA 3. Naušnica sa spiralnim privjeskom unutar tipološke sheme Z. Čilinske (Čilinská 1975).

ABBILDUNG 3. Ohrring mit einem spiralförmigen Anhänger im Rahmen des typologischen Schema von Z. Čilinská (Čilinská 1975).

Naušnicama sa spiralnim privjeskom znatno je više pažnje posvećeno u okviru starije srednjoevropske literature. Z. Čilinska određuje ove naušnice kao tip VIII (inačica A) i smatra ih posebnom skupinom jednostavnog predvelikomoravskoga nakita za čiju izradu nije potrebno zlatarsko umijeće (sl. 3). ${ }^{64}$ Zaključuje da je riječ o narodnom nakitu proizvedenom u domaćim radionicama, čiji su nositelji bili Slaveni u avarskom kaganatu. Nakit se pojavljuje na rubnim dijelovima kasnoavarodobnih kosturnih grobalja, a početak produkcije pada mu u prijelaz 7. na 8. stoljeće.

Potvrdu da je u pitanju narodni nakit Čilinska vidi u njegovoj dugoj uporabi na slavenskim grobljima tijekom 9. i 10. stoljeća. Odraz je društvenog statusa ukopanih, a nezahtjevnost izrade i metal od kojeg su naušnice napravljene omogućava njihovo povezivanje sa ženama nižih društvenih slojeva. Najbrojnije su u srednjem i donjem Podunavlju, koje je najvjerojatnije i područje njihova podrijetla, dok slični primjerci u južnom Sibiru, Kazahstanu i Permu nisu povezani s podunavskim naušnicama.
Im Zusammenhang mit dem Fund aus Grab 5 in Gorica in Stranče (Kat. Nr. 16) hebt Ž. Cetinić hervor, dass ein Teil der Ohrringe mit einem Anhänger in Form eines spiralen Kegels mit dem Repertoire der Bijelo Brdo-Kultur verbunden ist und ein Teil der Kärnten-Köttlach-Kultur zugeschrieben wird. ${ }^{57}$

I. Kamenjarin ist hingegen der Überzeugung, dass der Ohrring aus Grab 30 in Stombrate (Kat. Nr. 18) mit Hinblick auf die Länge des kegelförmigen Anhängers aus Spiraldraht nicht der Bijelo Brdo-Kultur zugeordnet werden kann und ordnet sie zeitlich um die Mitte des 9. Jahrhunderts. ${ }^{58}$

Der Siedlungsfund aus Prečno Pole I (Kat. Nr. 13) wurde in den Zeitraum vom Ende des 8. bis zur Mitte des 9. Jahrhunderts datiert. ${ }^{59}$

Ich selbst nahm 2009 kurz Bezug auf die Funde aus Dalmatien, und wies auf die weite Verbreitung verwandter Ohrringe in Mittel- und Südosteuropa sowie auf ihre unterschiedliche kulturelle Zugehörigkeit und unterschiedliche Datierung hin.$^{60} \mathrm{Zu}$ dieser Zeit ordnete ich die dalmatinischen Exemplare allgemein um die Mitte des 9. Jahrhunderts. ${ }^{61}$

In der neueren kroatischen archäologischen Literatur befassten sich vor allem Ž. Demo i V. Sokol ausführlicher mit Ohrringen mit einem spiralen Anhänger.

Demo weist darauf hin, dass es sich hierbei um ein sporadisches Auftreten innerhalb des Bijelo Brdo-Kulturkreises handelt, bei denen Ohrringe mit einem spiralförmigen Anhänger nicht viel mehr sind als eine Reminiszenz an ähnliche Schmuckformen, die im awaroslawischen Kreis des späten 8. und frühen 9. Jahrhunderts entwickelt wurden. ${ }^{62}$ Sie waren unter den Bewohnern der karolingischen Zeit in Ostösterreich und Westungarn im 9. und frühen 10. Jahrhundert weit verbreitet. Demo unterteilt die Bijelo Brdo-Ohrringe mit spiralem Anhänger in mehrere Varianten: Die häufigsten Ohrringe sind jene mit einem nach unten breiter werdenden Anhänger, etwas seltener sind Ohrringe mit einem zylindrischen Anhänger, und nur ein Exemplar hat ein sich nach unten verjüngendes Ende. Sie sind charakteristisch für Mädchengräber und kommen nur gelegentlich in Gräbern erwachsener Frauen vor. Innerhalb der Bijelo Brdo-Kultur treten diese Ohrringe um die Wende aus dem 10. ins 11. Jahrhundert auf, wobei sie am intensivsten im ersten Viertel oder im ersten Drittel des 11. Jahrhunderts getragen wurden. Aus der Mode geraten sie endgültig nach Mitte des 11 . Jahrhunderts.

\footnotetext{
57 Cetinić 2011, 199.

58 Kamenjarin 2009, 95.

59 Sekelj Ivančan 2010, 140-141, 257, T. 37, 230.

60 Für spätawarische Funde, siehe Čilinská (1975, 76-77); für mitteleuropäische Funde, siehe Szőke (1992, 118-120); für Funde in frühungarischen Gräbern siehe Szőke (1962, 39-41); für Funde im Kontext der Bijelo Brdo-Kultur, siehe Gie sler (1981, 129, n. 319); für mazedonische und albanische Funde, siehe Манева (1992, 44-45) und Вукосављевић $(2012,22)$.

61 Petrinec 2009, 206-207.

62 Demo 2009, 449-452. Auf S. 449-450 findet sich ein vollständiges Literaturverzeichnis, das sich mit diesen Ohrringen beschäftigt, sowie eine Karte der Bijelo Brdo Gräberfelder, auf denen sie gefunden wurden.
} 


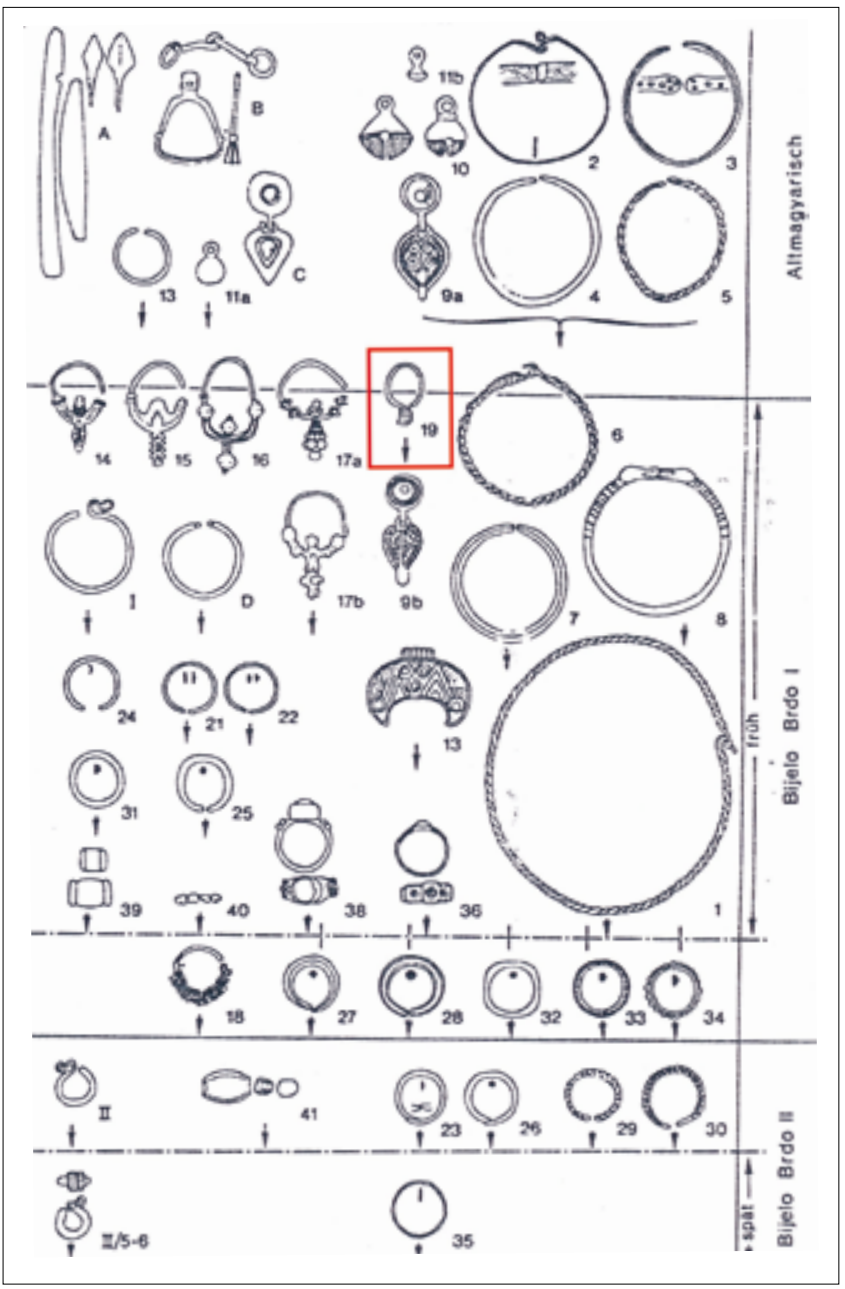

SLIKA 4. Naušnica sa spiralnim privjeskom unutar kronologije J. Gieslera za bjelobrdsku kulturu (Giesler 1981).

ABBILDUNG 4. Ohrring mit einem spiralförmigen Anhänger im Rahmen der Chronologie von J. Giesler für die Bijelo Brdo-Kultur (Giesler 1981).

J. Giesler u tipološkom razvrstavanju bjelobrdskog materijala ove je naušnice 1981. godine označio kao tip 19 (sl. 4). ${ }^{65}$ Naglašava kako je u starijoj srednjoevropskoj literaturi vladao velik interes za njih zbog toga što se smatralo da su tipološki povezane s karičicama sa S-zavšetkom. Osvrće se na tu stariju literaturu (G. Fehér, B. Szöke, A. Kralovánsky, W. Szymanski) pa za detaljniji uvid upućujem na njegov tekst. ${ }^{66}$ Samog Gieslera ipak prvenstveno zanima opredjeljivanje ovih naušnica unutar bjelobrdske kulture. ${ }^{67}$ Prema njegovu mišljenju one su vrlo rijetko povezane $s$ bjelobrdskim inventarom stoga njihov broj ukazuje na mogućnost da se radi o starijim prikupljenim i preuporabljenim ulomcima. Kombinacije nalaza s kojima se pojavljuju u grobovima stavljaju njihovu pojavu u ranu fazu stupnja Bijelo Brdo I, a registrirane su
Nach der Auffassung von Ž. Demo befanden sich die Zentren ihrer Anfertigung in den südslawischen Regionen am Unterlauf der Drau.

V. Sokol bezieht sich nur auf Funde, die älter sind als die Ohrringe der Bijelo Brdo-Kultur. Er ist der Ansicht, dass die Exemplare aus Zagreb und Plavno aufgrund der unklaren Entdeckungsumstände nicht bestimmt werden können. Das Exemplar aus Vinodol und den Ohrring aus Stombrate datiert er in die Mitte des 9. Jahrhunderts, die Ohrringe aus Petoševci in Bosnien und Prečno Pole I in Podravina in die zweite Hälfte des 9. Jahrhunderts oder die erste Hälfte des 10. Jahrhunderts, während seiner Meinung nach die Exemplare aus Grab 162 neben der Kirche des Heiligen Kreuzes in Nin ins gesamte 9. Jahrhundert datiert werden können. ${ }^{63}$

Ohrringe mit spiralförmigem Anhänger fanden in der älteren mitteleuropäischen Literatur deutlich mehr Beachtung.

Z. Čilinská definiert diese Ohrringe als Typ VIII (Variante A) und betrachtet sie als eine gesonderte Gruppe einfacher vorgroßmährischer Schmuckstücke, deren Herstellung keine besondere Goldschmiedekunst erforderte (Abb. 3) ${ }^{64}$ Sie kommt zu dem Schluss, dass es sich um in lokalen Werkstätten hergestellten Volksschmuck handelt, deren Träger Slawen im Awarischen Kaganats waren. Dieser Schmuck tritt in Randbereichen spätawarischer Skelettgräberfelder auf, während der Beginn ihrer Herstellung in die Zeit der Wende aus dem 7. ins 8. Jahrhundert fällt.

Eine Bestätigung der Annahme, dass es sich um Volksschmuck handelt, sieht Čilinska in seiner langen Verwendungszeit auf slawischen Gräberfeldern während des 9. und 10. Jahrhunderts. Der Schmuck spiegelt den sozialen Status der Bestatteten wider, und die schlichte und anspruchslose Verarbeitung sowie das Metall, aus dem die Ohrringe hergestellt sind, erlaubt es diesen Schmuck mit Frauen aus niedrigen sozialen Schichten in Verbindung zu setzen. Sie sind am zahlreichsten in der mittleren und unteren Donauniederung, die höchstwahrscheinlich auch ihr Ursprungsgebiet darstellt, während ähnliche Exemplare aus Südsibirien, Kasachstan und Perm nicht mit den Ohrringen aus der Donauniederung in Verbindung stehen.

J. Giesler bezeichnete 1981 diese Ohrringe als Typ 19 in der typologischen Klassifikation des Bijelo Brdo-Materials (Abb. 4). ${ }^{65}$ Er wies darauf hin, dass in der älteren mitteleuropäischen Literatur großes Interesse an ihnen bestand, weil man davon ausging, dass sie typologisch mit den Ringlein mit S-Enden verbunden sind. Er bezieht sich auf diese ältere Literatur (G. Fehér, B. Szőke, A. Kralovánszky, W. Szymański), so dass ich daher auf seinen Text für einen detaillierteren Einblick verweise. ${ }^{66}$ Giesler selbst interessierte sich in erster Linie für die Zuordnung die-

\footnotetext{
65 Giesler 1981, 128-130.

66 Giesler 1981, 128.

67 Popis nalaza naušnica tipa 19 na grobljima bjelobrdske kulture (Giesler 1981, 129, bilj. 319).
}

\footnotetext{
63 Sokol 2019, 213-216.

64 Čilinská 1975, 76-77.

65 Giesler 1981, 128-130

66 Giesler 1981, 128.

67 Liste der Funde von Ohrringen des Typs 19 auf den Gräberfeldern der Bijelo Brdo-Kultur (Giesler 1981, 129, Anm. 319).
} 
i u već uznapredovaloj fazi istog stupnja, što dokazuje datacija srebrnim novcem Andrije I (1046. - 1060.). Nije zasigurno zabilježena njihova pojava u stupnju Bijelo Brdo II. ${ }^{68}$

U Gieslerovoj pak kronologiji za ketlašku kulturu ovaj tip naušnice opredijeljen je u pretketlaški horizont, odnosno u 9. stoljeće (sl. 5). ${ }^{69}$

Naušnicama sa spiralnim privjeskom najdetaljnije se pozabavio B. M. Szőke. ${ }^{70} \mathrm{Na}$ tragu ranijih spoznaja do kojih su došli V. Hrubý $i$ B. Szőke ovaj autor predlaže njihovu novu tipološku i kronološku klasifikaciju i dijeli ih u četiri skupine: ${ }^{11}$

1. naušnice s prema dolje suženim spiralnim privjeskom

2. naušnice s cilindričnim privjeskom, odnosno privjeskom jednake širine

3. naušnice s prema dolje proširenim spiralnim privjeskom

4. inačica tipova 2 i 3, kod koje se donji kraj spiralnog privjeska grana u petlje kroz koje su provješeni pokretni lančići.

Prvi tip s prema dolje suženim spiralnim privjeskom pojavljuje se u najmlađem horizontu kasnoavarodbnih grobalja te rijetko u najranijim grobljima karolinškog doba u gornjem Podunavlju. Poznat je i na Balkanu (Albanija). Za njegovo vremensko opredjeljivanje značajni su inventari dvaju grobova (grob 43 u Zalakomáru i grob 75 na groblju Auhof / Perg) prema kojima se može opredijeliti u prijelaz 8./9. stoljeće i prvu trećinu 9. stoljeća.

Drugi tip s cilindričnim privjeskom predstavlja prijelazni tip između tipova 1. i 3. Naušnice ovog tipa pojavljuju se u pojedinim grobovima s kraja avarskog razdoblja, ali ih većina pripada ranokarolinškom vremenu. Brojem registriranih primjeraka, kao i područjem rasprostranjenosti, preklapaju se stipom 1. Na osnovi pojedinih zatvorenih cjelina B. M. Szőke datira tip 2 u prvu polovinu, odnosno najkasnije do kraja druge trećine 9. stoljeća.

Treći tip se također pojavljuje još u pojedinim kasnoavarskim i karolinškodobnim grobovima, ali i kasnije, s pratećim materijalom koji označava niže društvene slojeve u doba mađarskog naseljavanja, kao i u nošnji običnoga mađarskog stanovništva u 10. stoljeću. Najintenzivnije su u uporabi u drugoj polovini 9. stoljeća. Rasprostranjene su na sjeverozapadnoj i dijelom jugoistočnoj periferiji ugarskog kraljevstva, što upućuje na to da se radi o nakitnom obliku preuzetom u mađarsku nošnju iz nekog pobliže neodredivoga stranog miljea. Nakon sredine 10. stoljeća, Mađari više ne nose ove naušnice, ali se one svejedno zadržavaju u uporabi, a najmlađi je primjerak registriran u grobu 110 u Ellendu I, gdje je otkriven s denarom Andrije I (1046. - 1060.). Moda nošenja ovih naušnica napušta se oko sredine 11 . stoljeća. ser Ohrringe innerhalb der Bijelo Brdo-Kultur. ${ }^{67}$ Seiner Meinung nach werden sie sehr selten mit dem Bijelo Brdo-Inventar in Verbindung gebracht, daher weist ihre Anzahl auf die Möglichkeit hin, dass es sich um ältere gesammelte und wiederverwendete Fragmente handelt. Die Mischung von Funden, mit denen sie in Gräbern auftreten, ordnen sie in die frühe Phase der Stufe I der Bijelo Brdo-Kultur, wobei sie auch in der bereits fortgeschrittenen Phase der gleichen Stufe registriert wurden, was die Datierung mit Silbermünzen von Andreas I (1046-1060) beweist. Ihr Vorkommen in der Stufe II der Bijelo Brdo-Kultur kann nicht mit Sicherheit belegt werden. ${ }^{68}$

In Gieslers Chronologie für die Köttlach-Kultur hingegen wird dieser Typ Ohrring dem Vor-Köttlach Horizont zugeschrieben, bzw. ins 9. Jahrhundert datiert (Abb. 5) ${ }^{69}$

B. M. Szőke befasste sich am ausführlichsten mit den Ohrringen mit spiralförmigem Anhänger. ${ }^{70}$ In Anlehnung an die früheren Erkenntnisse von V. Hrubý und B. Szőke, schlägt dieser Autor eine neue typologische und chronologische Klassifikation für sie vor und unterteilt sie in vier Gruppen: ${ }^{71}$

\section{Ohrringe mit einem nach unten verjüngenden spiralförmigen Anhänger}

2. Ohrringe mit einem zylindrischen Anhänger bzw. einem gleich breiten Anhänger

3. Ohrringe mit einem nach unten breiter werdenden spiralförmigen Anhänger

4. Variante der Typen 2 und 3, bei der das untere Ende des spiralförmigen Anhängers in Schleifen verzweigt, durch die bewegliche Kettchen durchgezogen sind

Der erste Typ mit einem nach unten verjüngenden spiralförmigen Anhänger erscheint im jüngsten Horizont der spätawarischen Gräberfelder und nur selten auf den frühesten Gräberfeldern aus der Karolingerzeit in der oberen Donauniederung. Auch auf dem Balkan (Albanien) ist er bekannt. Für seine zeitliche Einordnung sind die Inventare von zwei Gräbern (Grab 43 in Zalakomár und Grab 75 auf dem Gräberfeld Auhof / Perg) von Bedeutung, nach denen er in die Zeit der Wende aus dem 8. ins 9. Jahrhundert und das erste Drittel des 9. Jahrhunderts zugeordnet werden kann.

Der zweite Typ mit einem zylindrischen Anhänger stellt einen Übergangstyp zwischen Typ 1 und 3 dar. Ohrringe dieses Typs wurden in einigen Gräbern vom Ende der awarischen Periode registriert, aber die Mehrheit von ihnen datiert in die frühkarolingische Zeit. In der Anzahl der registrierten Exemplare sowie in ihrem Verbreitungsgebiet stimmen sie mit Typ 1 überein. Aufgrund einzelner geschlossener Einheiten datiert B.M. Szőke Typ 2 in die erste Hälfte bzw. spätestens ans Ende des zweiten Drittels des 9. Jahrhunderts.

\footnotetext{
68 Prema Giesleru $(1981,129)$ iznimka su naušnice s područja Poljske, koje pripadaju 12. i 13. stoljeću.

69 Giesler 1980, 86, sl. 1,6

70 Szőke 1992, 117-121.

71 Uz svaku izdvojenu skupinu Szőke donosi i popis nalazišta uz navođenje grobova u kojima su naušnice pronađene i literaturu u kojoj su objavljene.
}

68 Gemäß Giesler $(1981,129)$ sind die Ohrringe aus dem Gebiet Polens, die aus dem 12. und 13. Jahrhundert stammen, eine Ausnahme.

\footnotetext{
69 Giesler 1980, 86, Abb. 1,6.
}

70 Szőke 1992, 117-121.

71 Zu jeder gesonderten Gruppe gibt Szőke auch eine Liste der Fundorte mit Angaben zu den Gräbern, in denen die Ohrringe entdeckt wurden, sowie die Literatur, in der sie veröffentlicht wurden. 
Sva tri prva tipa, dakle, susreću se u Karpatskoj kotlini, u zapadnom dijelu kasnoavarskog kaganata, na prijelazu 8. u 9. stoljeće. Odatle se proširuju prema zapadu i sjeverozapadu, a kasnije i prema jugu. Posljednji tip 4 predstavlja modificiranu inačicu naušnica tipa 2 i 3 te nastaje na predlošku naušnica karantanskog tipa s privjescima u obliku pokretnih lančića. Taj posljednji Szőkeov tip u Gieslerovoj je kronologiji za ketlašku kulturu svrstan u pretketlaški horizont, jednako kao i ostale naušnice sa spiralnim privjeskom (sl. 5). ${ }^{72}$

Veća koncentracija nalaza naušnica sa spiralnim privjeskom zapaža se u rumunjskom i bugarskom Podunavlju, gdje su datirane u rasponu od 8. do početka 10. stoljeća, a nekoliko primjeraka iz srpskog Podunavlja (Donji Milanovac, Ritopek) također se široko datira od 9. do 12. stoljeća. ${ }^{73}$

Novija istraživanja iznijela su na svjetlo dana velik broj nalaza na području sjeverne Makedonije, ali i Albanije, gdje su registrirane u grobovima Komani - Kruje (komanske) kulture. ${ }^{74}$ Većina se vremenski opredjeljuje u kraj 8. i prvu polovinu 9. stoljeća, što u posljednje vrijeme podupiru i rezultati radiokarbonskog datiranja na pojedinim lokalitetima. To su ujedno i groblja na kojima se pojavljuje kasnoavarski materijal. ${ }^{75}$ Riječ je isključivo o primjercima kojima se spiralni privjesak sužava prema dolje. Neki primjerci s cilindričnim spiralnim privjeskom iz sjeverne Makedonije mlađeg su datuma i opredjeljuju se u 11. i 12. stoljeće.

Poput naušnica s viticama na donjem luku karike, i naušnice s privjeskom od spiralno uvijene žice pojavljuju se u raznim inačicama i u velikom vremenskom rasponu na širokom prostoru srednje i jugoistočne Europe. Mogu se razvrstati u još više regionalnih i kronoloških skupina nego prethodni tip:

1. Prvu veliku skupinu tvore naušnice $s$ kasnoavarodobnih grobalja (SPA III). Pojavljuju se u ženskim i dječjim grobovima na perifernim dijelovima grobalja, a datiraju se u kraj 8. i početak 9. stoljeća.

2. Drugoj skupini pripadaju naušnice karolinškodobnih grobalja u rasponu od prijelaza 8./9. stoljeće do sredine 9. stoljeća, na području Gornje i Donje Austrije i zapadne Mađarske. Ova groblja dijelom se vremenski preklapaju s kasnoavarodobnim grobljima, ali i grobljima najstarijega ukupnog horizonta u Dalmaciji koja pripadaju razdoblju formiranja Hrvatske kneževine.
Der dritte Typ kommt gleichfalls in einigen spätawarischen und karolingischen Gräbern vor, aber auch später, mit begleitenden Funden, die charakteristisch sind für die unteren sozialen Schichten zur Zeit der ungarischen Landnahme sowie die Bekleidung der einfachen ungarischen Bevölkerung im 10. Jahrhundert. Sein Gebrauch war am intensivsten in der zweiten Hälfte des 9. Jahrhunderts. Das Ausbreitungsgebiet dieser Ohrringe liegt im nordwestlichen und teilweise südöstlichen Randgebiet des Königreichs Ungarn, was darauf hinweist, dass es sich um eine Schmuckform handelt, die in die ungarische Tracht aus einem nicht bestimmbaren ausländischen Umfeld übernommen wurde. Nach der Mitte des 10. Jahrhunderts tragen die Ungarn diese Ohrringe zwar nicht mehr, doch bleiben sie noch immer in Verwendung. Das jüngste Exemplar wurde in Grab 110 in Ellend I registriert, wo es mit dem Denar von Andreas I. (1046-1060) entdeckt wurde. Das Tragen dieser Ohrringe kam um die Mitte des 11. Jahrhunderts aus der Mode.

Die ersten drei Typen sind somit im Karpatenbecken im westlichen Teil des spätawarischen Khaganats um die Wende vom 8. ins 9. Jahrhundert anzutreffen. Von dort breiten sie sich nach Westen und Nordwesten und später auch nach Süden aus. Der letzte Typ 4 stellt eine modifizierte Variante der Ohrringe Typ 2 und 3 dar, der auf der Vorlage der Kärntner-Ohrringe mit Anhängern in Form von beweglichen Kettchen entstand. Dieser von Szőke definierte letzte Typ ist in Gieslers Chronologie für die Köttlach-Kultur dem Vor-Köttlach Horizont zugeordnet, wie auch die anderen Ohrringe mit einem spiralförmigen Anhänger (siehe Abb. 5)..$^{72}$

Eine höhere Konzentration an Funden von Ohrringen mit einem spiralförmigen Anhänger ist in der rumänischen und bulgarischen Donauniederung zu beobachten, wo sie in den Zeitraum vom 8. bis zum Beginn des 10. Jahrhunderts datieren. Zudem gibt es auch mehrere Exemplare aus der serbischen Donauniederung (Donji Milanovac, Ritopek), die gleichfalls in die zeitlich weitumspannende Periode vom 9. bis. 12 Jahrhundert datiert werden. $^{73}$

Jüngste Forschungen haben eine große Anzahl von Funden im Gebiet Nordmazedoniens aber auch in Albanien ans Licht gebracht, wo sie in den Gräbern der Komani-Kruje (komanischen)Kultur registriert wurden. ${ }^{74}$ Die meisten von ihnen werden dem Ende des 8. und der ersten Hälfte des 9. Jahrhunderts zuge-

\footnotetext{
72 Giesler 1980, 86, sl. 1, 5.

Za Bugarsku, vidi Григоров (2007, 15, 71, sl. 3, 1-8; 161, sl. 24); Za Bugarsku i Rumunjsku vidi Fiedler (1992, 1: 172-173, sl. 38, 3-6). Za Srbiju vidi Бајаловић Хаџи-Пешић (1984, 2), Минић (1970, 31-32), Szekeres, Szekeres (1996, Т. XXXVI/12), Jovanović, Vuksan (2005, 207, bilj. 173) і Радичевић (2007, 89).

74 Манева 1992, 44-45, Т. 17; Вукосављевић 2012, 22, sl. 108-114, gdje su navedena i sva nalazišta ovog tipa naušnica u okviru komanske (Komani - Kruje) kulture s područja Albanije, sjeverne Makedonije i Crne Gore.

75 Na lokalitetu Komani četiri naušnice sa spiralnim privjeskom pojavljuju se u najmlađem skeletnom grobu (G 321) toga groblja, čija je datacija u 8. stoljeće potvrđena radiokarbonskom analizom. U istom su sloju grobova registrirani i kasnoavarski nalazi tipični za drugu polovinu 8. stoljeća. Usp. Nallbani (2017, 32, sl. 5; 331, sl. 6).
}

72 Giesler 1980, 86, Abb. 1,5

73 Für Bulgarien, siehe Григоров (2007, 15, 71, Abb. 3, 1-8; 161, Abb. 24); Für Bulgarien und Rumänien, Fiedler (1992, 1: 172-173, Abb. 38, 3-6). Für Serbien, Бајаловић - Хаџи-Пешић (1984, 22), Минић (1970, 31-32), Szekeres, Szekeres (1996, T. XXXVI/12), Jovanović, Vuksan (2005, 207, bilj. 173) und Радичевиђ $(2007,89)$.

74 Манева 1992, 44-45, Т. 17; Вукосављевић 2012, 22, Abb. 108-114 wo auch alle Fundorte dieses Typs Ohrrings im Rahmen der komanischen (Komani - Kruje) Kultur aus den Gebieten Albaniens, Nordmazedoniens und Montenegro aufgeführt sind 


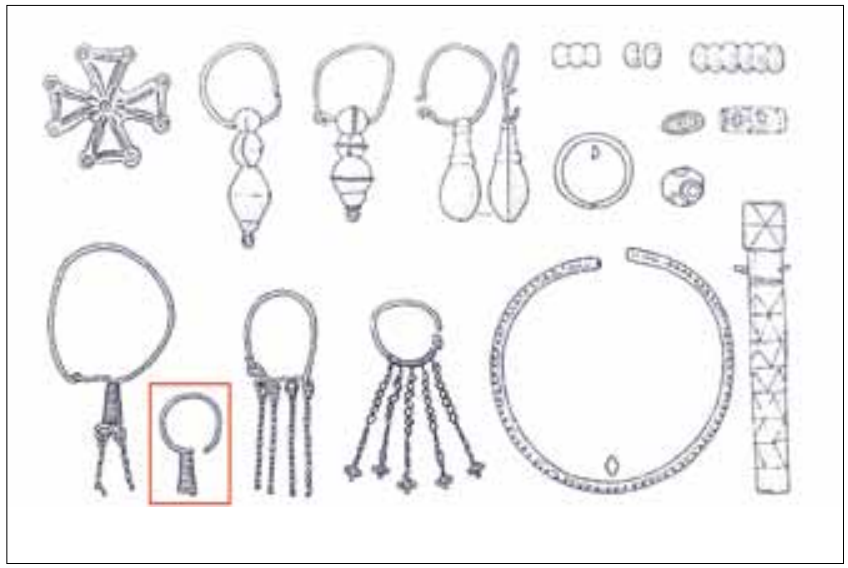

SLIKA 5. Nalazi pretketlaškog horizonta, prema J. Giesleru, s označenom naušnicom sa spiralnim privjeskom (Giesler 1980).

ABBILDUNG 5. Funde aus dem Vor-Köttlach Horizont nach J. Giesler mit gekennzeichnetem Ohrring mit einem spiralförmigen Anhänger (Giesler 1980).

3. Trećoj skupini pripadaju naušnice uglavnom druge polovine 9. i prve polovine 10. stoljeća s područja Karpatske kotline. Riječ je o grobljima različite kulturne pripadnosti prema tradicionalnom kulturno-povijesnom pristupu (velikomoravska kultura, ranomađarski horizont i dr.). Vremenski se s njima preklapaju i groblja mlađega ukopnog sloja u Dalmaciji (starohrvatska ili dalmatinsko-hrvatska groblja) te groblja kasnog stupnja ketlaške kulture.

4. Četvrtoj skupini pripadaju naušnice s bjelobrdskih grobalja druge polovine 10. i prve trećine 11 . stoljeća, koje su u uporabi najkasnije do sredine 11 . stoljeća.

5. Peta skupina su naušnice bugarskog, rumunjskog i srpskog Podunavlja datirane u čitavom rasponu trajanja naušnica prvih triju skupina s pojavom i u nešto kasnijem vremenu, na što upućuju pojedini nalazi iz Srbije, ali i pojedini primjerci iz sjeverne Makedonije.

6. Šestu skupinu čine naušnice iz Albanije, sjeverne Makedonije i Crne Gore vezane uz Komani - Kruje (komansku) kulturu i datirane u 8. i početak 9. stoljeća. Vremenski se groblja s kojih potječu također preklapaju s kasnoavarodobnim grobljima, s grobljima ranokarolinškog doba u Karpatskoj kotlini, ali i grobljima najstarijega ukopnog horizonta u Dalmaciji.

Napominjem da se sve tri zastupljene inačice (naušnice sa spiralnim privjeskom koji se sužava prema dolje, naušnice s cilindričnim privjeskom jednake širine i naušnice s prema dolje proširenim privjeskom) pojavljuju u svim ovdje izdvojenim skupinama, s tim da pojedine od ovih triju inačica ponegdje prevladavaju; npr. među albanskim naušnicama to su one sužene prema dnu, a među naušnicama bjelobrdske kulture one s kraćim, prema dnu proširenim privjeskom načinjenim od debele žice. Oblik i dužina privjeska, međutim, nisu presudni u kronološkom smislu i ako je riječ o nalazima nepoznatih okolnosti, otkrića ne mogu biti argument za vremensko opredjeljivanje naušnica. schrieben, was in letzter Zeit durch die Ergebnisse der Radiokarbondatierung an vereinzelten Orten gestützt wird. Dabei geht es ebenfalls um Gräberfelder, auf denen spätawarisches Material anzutreffen ist. ${ }^{75}$ Es handelt sich dabei ausschließlich um Exemplare, bei denen sich der spiralförmige Anhänger nach unten verjüngt. Einige Exemplare mit einem zylindrischen spiralförmigen Anhänger aus Nordmazedonien stammen aus jüngerer Zeit und werden dem 11. und 12. Jahrhundert zugeordnet.

Wie im Fall der Ohrringe mit Ranken im unteren Ringbogen treten die Ohrringe mit Anhänger aus spiral gewundenem Draht in verschiedenen Varianten und über einen langen Zeitraum in einem weiten Gebiet Mittel- und Südosteuropas auf. Man kann sie zudem in noch mehr regionale und chronologische Gruppen als den vorherigen Typ unterteilen:

1. Die erste große Gruppe besteht aus Ohrringen von spätawarischen Gräberfeldern (SPA III), die in Frauen- und Kindergräbern an den Randbereichen der Gräberfelder vorzufinden sind und aus dem späten 8 . und frühen 9 . Jahrhundert stammen.

2. Zur zweiten Gruppe gehören Ohrringe von karolingischen Gräberfeldern aus der Wendezeit vom 8. ins 9. Jahrhundert bis Mitte des 9. Jahrhunderts aus Gebieten Ober- und Niederösterreichs und Westungarns. Diese Gräberfelder überschneiden sich zeitlich teilweise mit den spätawarischen Gräberfeldern aber auch mit den Gräberfeldern des ältesten Bestattungshorizonts in Dalmatien, die in die Entstehungszeit des Kroatischen Fürstentums datieren.

3. Die dritte Gruppe umfasst überwiegend Ohrringe aus der zweiten Hälfte des 9. und der ersten Hälfte des 10. Jahrhunderts aus dem Gebiet des Karpatenbeckens. Dabei handelt es sich um Gräberfelder unterschiedlicher kultureller Zugehörigkeit nach dem traditionellen kulturhistorischen Ansatz (großmährische Kultur, früher ungarischer Horizont usw.). Zeitlich überschneiden sie sich ebenfalls mit den Gräberfeldern der jüngeren Bestattungsschicht in Dalmatien (altkroatische oder dalmatinisch-kroatische Gräberfelder), sowie den Gräberfeldern der späten Stufe der Köttlach-Kultur.

4. Die vierte Gruppe beinhaltet Ohrringe von den Gräberfeldern der Bijelo Brdo-Kultur aus der zweiten Hälfte des 10. und dem ersten Drittel des 11 . Jahrhunderts, die spätestens bis zur Mitte des 11. Jahrhunderts verwendet wurden.

5. Die fünfte Gruppe bilden Ohrringe aus der bulgarischen, rumänischen und serbischen Donauniederung, die in die gesamte Zeitspanne der Ohrringe aus den ersten drei Gruppen datieren. Einige Funde aus Serbien sowie einige Exemplare aus Nordmazedonien deuten jedoch darauf hin, dass sie auch zu einem späteren Zeitpunkt noch vorkommen.

75 Am Fundort Komani treten vier Ohrringe mit spiralförmigem Anhänge im auf diesem Gräberfeld jüngsten Skelettgrab (G 321) auf, dessen Datierung ins 8. Jahrhundert mit der Radiokarbondatierung bestätigt wurde. In der gleichen Gräberschicht entdeckte man spätawarische Funde, die für die zweite Hälfte des 8. Jahrhunderts kennzeichnend sind. Vergleiche Nallbani (2017, 32, Abb. 5; 331, Abb. 6). 
Preostaje svrstati nalaze iz Hrvatske i Bosne i Hercegovine. Prvoj skupini nedvojbeno pripadaju dvije naušnice iz grobova $14 \mathrm{i}$ 161 s nekropole Privlaka - Gole njive (kat. br. 12a-b). Oba groba iz kojih potječu pripadaju kasnoavarskom razdoblju i imaju brojne paralele u srodnim grobljima kasnoavarskog miljea na prostoru Karpatske kotline. ${ }^{76}$ Istom razdoblju, prema ostalim pokazateljima, pripada i naušnica iz naselja u Prečnom polu I u Podravini (kat. br. 13). ${ }^{77}$

Drugoj skupini vremenski pripada grob 162 uz Crkvu sv. Križa u Ninu (kat. br. 17b) u kojem je, osim naušnice sa spiralnim privjeskom, otkrivena i naušnica s karikom povijenom u petlje te ogrlica s nanizanim ulomcima antičkog stakla. Grob pripada najstarijem sloju ukapanja u kojem je otkriven i zlatni solid Konstantina V. Kopronima i Lava IV., karakterističan za grobne inventare kasnog 8. i ranog 9. stoljeća na području hrvatske kneževine.

Naušnici iz Zagreba (kat. br. 14) okolnosti otkrića nisu poznate, ali s obzirom na ostale nalaze $s$ istog položaja, najvjerojatnije pripada 9. stoljeću, a mogla bi se povezati s trećom skupinom. ${ }^{78}$ Toj skupini treba pripisati i naušnicu iz Petoševaca u sjeverozapadnoj Bosni (kat. br. 15) jer nedvojbeno pripada groblju starijem od početka bjelobrdske kulture, a potječe iz sloja grobova s pojedinačnim nalazima koji se tradicionalno pripisuju velikomoravskoj, staromađarskoj, starohrvatskoj (dalmatinsko-hrvatskoj) i ketlaškoj kulturi. ${ }^{79}$ Vremenski se s trećom skupinom može povezati i naušnica iz groba 30, na Stombratama u Bijaćima (kat. br. 18), te iz groba 5 na Gorici u Strančama (kat. br. 16), koje se mogu opredijeliti u drugu polovinu 9. ili vjerojatnije u prvu polovinu 10. stoljeća. Na oba ova groblja pojavljuju se nalazi koji se tradicionalno pripisuju ketlaškoj kulturi, a zastupljena su i oba tipa ovdje razmatranih naušnica. S obzirom na nepoznate okolnosti otkrića, naušnicu s groblja Međine u Plavnom (kat. br. 19) teško je opredijeliti, a sagledavajući ostale nalaze s toga groblja, najvjerojatnije pripada trećoj skupini. ${ }^{80}$

Četvrtoj skupini vezanoj uz groblja bjelobrdske kulture pripadaju naušnice iz Vukovara (kat. br. 20) i iz Bijelog Brda (kat. br. 21a-b), a s obzirom na popratni nalaz karičice s raskovanim S-završetkom, vjerojatno i naušnica s Vijenca Ivana Meštrovića u Osijeku (kat. br. 22). ${ }^{81}$ Istom vremenskom razdoblju, 10. ili početku 11. stoljeća, pripada i naušnica iz groba 89 uz Crkvu sv. Križa u Ninu (kat. br. 17a), otkrivena u sloju grobova koji se tradicionalno pripisuje starohrvatskoj kulturi. ${ }^{82}$

\footnotetext{
76 Šmalcelj Novaković 2015, 18-19.

Sekelj Ivančan 2010, 140-141.

Demo 2007, 23-24

Žeravica 1986, 134, TII, 12/19. Opširnije o Petoševcima, kao i o drugim grobljima sjeverozapadne Bosne, vidi kod Šmalcelj (2012) gdje je navedena i sva literatura koja se na njih odnosi.

$80 \quad$ Nalazi pohranjeni u Muzeju hrvatskih arheoloških spomenika upućuju na zaključak da na groblju u Međinama nije bilo grobova najstarijega ukopnog horizonta pa naušnica (kao i njih još nekoliko) vjerojatno pripada kasnijem 9. stoljeću.

81 Bulat 1968, 11-12, T. I, 1-2.

82 Dataciju ovog sloja u navedeno razdoblje potvrđuje i nalaz bizantskoga relikvijarnog križa u grobu 188, koji pripada istom ukopnom sloju (usp. Petrinec 2014, 70-71).
}

6. Die sechste Gruppe besteht aus Ohrringen aus Albanien, Nordmazedonien und Montenegro, die mit der Spätstufe der Komani-Kruje-Kultur verbunden und ins 8 . und frühe 9 . Jahrhundert datiert sind. Zeitlich gesehen überschneiden sie sich mit den Gräberfeldern, von denen sie stammen, aber auch mit spätawarischen Gräberfeldern und jenen aus der frühen Karolingerzeit im Karpatenbecken, sowie den Gräberfeldern mit dem ältesten Bestattungshorizont in Dalmatien.

An dieser Stelle möchte ich darauf hinweisen, dass alle drei vertretenen Varianten (Ohrringe mit einem nach unten verjüngenden spiralförmigen Anhänger, Ohrringe mit einem gleich breiten zylindrischen Anhänger und Ohrringe mit einem nach unten breiter werdenden spiralförmigen Anhänger) in allen hier angeführten Gruppen auftreten, wobei vereinzelte dieser drei Varianten mancherorts überwiegen; bei den albanischen Ohrringen überwiegen beispielsweise die nach unten verjüngenden Exemplare, bei den Ohrringen aus der Bijelo Brdo-Kultur jene mit einem kürzeren, nach unten ausbreitendem Anhänger aus dickem Draht. Die Form und Länge des Anhängers sind im chronologischen Sinne jedoch nicht entscheidend und können, wenn es sich um Funde mit unbekannten Entdeckungsumständen handelt, kein Argument für die zeitliche Einordnung der Ohrringe sein.

Es bleibt die Klassifizierung der Funde aus Kroatien und Bosnien und Herzegowina. Zur ersten Gruppe gehören zweifellos zwei Ohrringe aus den Gräbern 14 und 161 von der Nekropole Privlaka-Gole njive (Kat. Nr. 12a-b). Beide Gräber, in denen sie entdeckt wurden, stammen aus der spätawarischen Zeit und weisen zahlreiche Parallelen zu verwandten Gräberfeldern aus dem spätawarischen Umfeld im Karpatenbecken auf. ${ }^{76}$ Anhand der übrigen Hinweise ist davon auszugehen, dass auch der Ohrring aus der Siedlung in Prečno Pole I in der Podravina aus derselben Zeit stammt (Kat. Nr. 13). ${ }^{77}$

Zeitlich gesehen ist Grab 162 neben der Kirche des Heiligen Kreuzes in Nin (Kat. Nr. 17b) der zweiten Gruppe zuzuschreiben. In ihm fand man, außer einem Ohrring mit einem spiralförmigen Anhänger, auch einen Ohrring mit einem in Schleifen gebogenen Ring, sowie eine Halskette mit aufgereihten Fragmenten antiken Glases. Das Grab gehört zur ältesten Bestattungsschicht, in der auch ein Goldsolid von Konstantin V. Kopronymos und Leo IV entdeckt wurde, der charakteristisch ist für Grabinventare des späten 8. und frühen 9. Jahrhunderts auf dem Gebiet des Kroatischen Fürstentums.

Die Entdeckungsumstände des Ohrrings aus Zagreb (Kat. Nr. 14) sind nicht bekannt, aber angesichts der anderen Funde vom selben Fundort datiert er höchstwahrscheinlich ins 9. Jahrhundert und könnte mit der dritten Gruppe in Verbindung stehen. ${ }^{78}$ Der Ohrring aus Petoševci im Nordwesten Bosniens (Kat. Nr. 15) sollte ebenfalls dieser Gruppe zugeordnet werden,

\footnotetext{
76 Šmalcelj Novaković 2015, 18-19.

Sekelj Ivančan 2010, 140-141.

Demo 2007, 23-24
} 


\section{Zaključak}

Dva tipa naušnica o kojima je bilo riječi u starijoj su arheološkoj literaturi pripisivana raznim arheološkim kulturama i raznim razdobljima:

1. avaro-slavenskoj kulturi ili kasnoavarodobnom horizontu (8. i početak 9. stoljeća)

2. Komani - Kruje (komanskoj) kulturi (8. i početak 9. stoljeća)

3. ranokarolinškom razdoblju (prva polovina 9. stoljeća)

4. pretketlaškom horizontu (druga polovina 9. stoljeća)

4. velikomoravskoj kulturi (9. stoljeće)

5. ketlaškoj kulturi (10. i prva polovina 11. stoljeća)

6. bjelobrdskoj kulturi (10. i 11. stoljeće)

7. starohrvatskoj (dalmatinsko-hrvatskoj) kulturi (10. - prva polovina 11. stoljeća).

Rasprostranjenost je obaju tipova široka i nisu karakteristični samo za Podunavlje i Karpatsku kotlinu, kakvo je bilo prevladavajuće mišljenje u starijoj srednjoevropskoj literaturi, već dosežu Poljsku, Srbiju, Rumunjsku, Bugarsku, sjevernu Makedoniju i Grčku. Prvi je tip naušnica datiran u rasponu od 10. do 14. stoljeća, a drugi od prijelaza 8./9. stoljeće do prijelaza 12./13. stoljeće. No, ipak se može konstatirati da najveći broj naušnica pripada vremenu od prijelaza 8./9. stoljeće do kraja 12. stoljeća. ${ }^{83}$ Riječ je o razdoblju, koje je u periodizaciji važećoj za područja koja su dio bizantskog kulturnog kruga, označeno kao srednjebizantsko razdoblje. Stoga, premda ni sama Hrvatska, a pogotovo udaljeniji prostori istočnih Alpa (Gornja i Donja Austrija) ne pripadaju izravno tom krugu, posve je jasno da je većina nakita s tih prostora nastala zapravo pod većim ili manjim bizantskim (mediteranskim) utjecajem koji se, osim u balkanskim zemljama, snažno odrazio i na avarodobnu materijalnu ostavštinu u Karpatskoj kotlini, na nakit Moravske, a kasnije i na ketlaški, staromađarski, pa i na lijevani bjelobrdski nakit, te nakit Hrvatske, Srbije, Bugarske i Grčke. ${ }^{84}$ Različite inačice istih tipova ili različita tehnika izrade ovisili su o mogućnostima radionica koje su ih proizvodile. Naušnice s donjim lukom ukrašenim spiralnim viticama i naušnice sa spiralnim središnjim ukrasom jednostavan su nakit za kojih nije bilo potrebno veliko zlatarsko umijeće. Za njih nije bila nužna izrada u opremljenoj zlatarskoj radionici, već su ih mogli izrađivati i putujući zlatari na licu mjesta. Unatoč širokoj rasprostranjenosti obaju tipova, kao i međusobnoj nepovezanosti pojedinih područja na kojima su registrirane, treba ipak uzeti u obzir da većina primjeraka pripada razdoblju 9. do 12. stoljeća pa se može zaključiti da su ove naušnice popularne upravo u srednjebizantskom razdoblju. da er zweifellos zu einem Gräberfeld gehört, das älter als der Beginn der Bijelo Brdo-Kultur ist und aus einer Grabschicht mit Einzelfunden stammt, die traditionell der großmährischen, altungarischen, altkroatischen (dalmatinisch-kroatischen) und der Köttlach -Kultur zugeschrieben wird. ${ }^{79}$ Der Ohrring aus Grab 30 in Stombrate in Bijaći (Kat. Nr. 18) und jener aus Grab 5 in Gorica in Stranče (Kat. Nr. 16) können ebenfalls zeitlich mit der dritten Gruppe verbunden und in die zweite Hälfte des 9 Jahrhunderts oder wahrscheinlicher in die erste Hälfte des 10 Jahrhunderts datiert werden. Auf beiden Gräberfeldern finden sich Funde, die traditionell der Köttlach-Kultur zugeschrieben werden. Auch beide hier betrachteten Ohrringtypen sind dort vertreten. Angesichts der unbekannten Entdeckungsumstände ist der Ohrring vom Gräberfeld Međine in Plavno (Kat. Nr. 19) nur schwer zu bestimmen. Betrachtet man die anderen Funde von diesem Gräberfeld, gehört er höchstwahrscheinlich auch zur dritten Gruppe. ${ }^{80}$

Zur vierten Gruppe, die mit den Gräberfeldern der Bijelo BrdoKultur verbunden ist, gehören die Ohrringe aus Vukovar (Kat. Nr. 20) und aus Bijelo Brdo (Kat. Nr. 21a-b), aber wahrscheinlich auch der Ohrring vom Vijenac von Ivan Meštrović in Osijek (Kat. Nr. 22) angesichts des begleitenden Fundes eines Ringleins mit geschmiedetem Ende in S-Form ${ }^{81}$ Aus der gleichen Zeit, bzw. dem 10. oder Anfang des 11. Jahrhunderts, stammt auch der Ohrring aus Grab 89 neben der Kirche des Heiligen Kreuzes in $\mathrm{Nin}$ (Kat. Nr. 17a), der in einer Grabschicht entdeckt wurde, die traditionell der altkroatischen Kultur zugeschrieben wird. ${ }^{82}$

\section{Schlussfolgerung}

Die beiden in der älteren archäologischen Literatur erwähnten Typen von Ohrringen wurden unterschiedlichen archäologischen Kulturen und unterschiedlichen Perioden zugeschrieben:

1. der awaroslawischen Kultur oder dem spätawarischen Horizont (8. und Anfang des 9. Jahrhunderts)

2. der Komani-Kruje-(komanischen) Kultur (8. und Anfang des 9. Jahrhunderts)

3. der frühkarolingischen Zeit (erste Hälfte des 9. Jahrhunderts)

4. dem vorköttlacher Horizont (8. und Anfang des 9. Jahrhunderts)

4. der großmährischen Kultur (9. Jahrhundert)

5. der Köttlach-Kultur (10. und erste Hälfte des 11. Jahrhunderts)

6. der Bijelo Brdo-Kultur (10. und 11. Jahrhundert)

7. der altkroatischen (dalmatinisch-kroatischen) Kultur (10. bis erste Hälfte des 11 . Jahrhunderts)
83 Nešto su mlađeg datuma samo pojedine naušnice prvog tipa iz rumunjskog dijela Dobrudže i iz Bugarske.

84 O srednjebizantskom nakitu opširnije, vidi (Bollók 2010; Petrinec 2014). O mediteranskom i bizantskom utjecaju na prostor srednje Europe (vidi Daim 2000; Nowotny 2005; Eichert 2017; 2018).
79 Žeravica 1986, 134, T. II, 12/19: Ausführlicher über Petoševci und andere Gräberfelder im nordwestlichen Bosnien siehe Šmalcelj (2012), wo auch die ge samte Literatur, die sich auf sie bezieht, angegeben ist.

80 Die Funde, die im Museum der kroatischen archäologischen Denkmäler verwahrt werden, deuten darauf hin, dass es auf dem Gräberfeld in Međine keine Gräber aus dem ältesten Bestattungshorizont gab, so dass der Ohrring (sowie mehrere andere) wahrscheinlich ins späte 9. Jahrhundert datiert.

81 Bulat 1968, 11-12, T. I, 1-2

82 Die Datierung dieser Schicht in den genannten Zeitraum bestätigt auch der Fund des byzantinischen Reliquienkreuzes in Grab 188, das der gleichen Bestattungsschicht angehört (Vergleiche Petrinec 2014, 70-71) 
Što se tiče nalaza Hrvatske i Bosne i Hercegovine, one se pojavIjuju u tri različita vremenska, ali i kulturno raznolika horizonta:

\section{Naušnice s kraja 8. i iz prve polovine 9. stoljeća}

Najstarije naušnice pripadaju razdoblju prijelaza 8./9. stoljeće. Riječ je o dva primjerka sa spiralnim privjeskom iz grobova 14 i 161 na Golim njivama u Privlaci, koji nedvojbeno pripadaju kasnoavarskom razdoblju (SPA III). Samo groblje s kojeg potječu smješteno je na južnoj granici Avarskog kaganata.

U razdoblje od kraja 8. do sredine 9. stoljeća, na temelju keramičkih nalaza, datira se naušnica iz stambenog objekta 096a na Prečnom polu I, u Podravni, unutar ranosrednjovjekovnog Torčeca. Ovo područje ne nalazi se u sastavu Avarskog kaganata, kanoavarski nalazi ovdje su sporadični, a vjerojatno je riječ o slavenskom naselju.

Zadnjim desetljećima 8. ili prvim desetljećima 9. stoljeća pripada i grob 162 s nalazom naušnice sa spiralnim privjeskom uz Crkvu sv. Križa u Ninu, otkriven u ukopnom sloju datiranom zlatnim solidom cara Konstantina V. i sina Lava IV. U kulturnom smislu, riječ je o horizontu koji pripada vremenu formiranja hrvatske kneževine. Istom vremenskom i kulturnom horizontu pripada i naušnica ukrašena spiralnim viticama iz groba 93 na Ždrijacu u Ninu.
Die Ausbreitung beider Typen ist groß und sie sind nicht nur für die Donauniederung und das Karpatenbecken charakteristisch, wie es in der älteren mitteleuropäischen Literatur überwiegend angenommen wurde, sondern sie erreichten auch Polen, Serbien, Rumänien, Bulgarien, Nordmazedonien und Griechenland. Der erste Ohrringtyp datiert in den Zeitraum vom 10. bis zum 14. Jahrhundert und der zweite in die Zeit der Wende aus dem 8. ins 9. Jahrhundert bis zur Wende aus dem 12. ins 13. Jahrhundert. Dennoch ist bestimmbar, dass die meisten Ohrringe aus der Zeit der Wende dem 8. ins 9. Jahrhundert bis zum Ende des 12. Jahrhunderts stammen. ${ }^{83}$ Es handelt sich dabei um eine Zeitspanne, die in der Periodisierung für Gebiete, die Teil des byzantinischen Kulturkreises sind, als mittelbyzantinische Periode gekennzeichnet ist. Obgleich Kroatien und insbesondere die entlegeneren Gebiete der Ostalpen (Ober- und Niederösterreich) nicht direkt diesem Kreis angehören, ist klar, dass die Mehrheit der Schmuckstücke aus diesen Gebieten tatsächlich unter mehr oder minder byzantinischem (mediterranem) Einfluss hergestellt wurden. Dieser Einfluss spiegelte sich, außer auf dem Balkan, auch stark im awarischen materiellen Erbe im Karpatenbecken wider, sowie im mährischen Schmuck und später auch im Köttlacher, altungarischen und sogar im gegossenen Schmuck der Bijelo Brdo-Kultur, aber auch im Schmuck aus Kroatien, Serbien, Bulgarien und Griechenland. ${ }^{84}$ Unterschiedliche Varianten der gleichen Typen oder unterschiedliche Herstellungstechniken hingen von den Fähigkeiten der Werkstätten $a b$, in denen sie hergestellt wurden. Ohrringe, deren untere Ringhälften mit spiralförmigen Ranken verziert sind, und Ohrringe mit einer spiralförmigen zentralen Verzierung sind einfache Schmuckstücke, die keine großen Goldschmiedekenntnisse erforderten. Eine gut ausgestattete Goldschmiedewerkstatt war für ihre Herstellung nicht notwendig, so dass sie auch von reisenden Goldschmieden vor Ort angefertigt werden konnten. Trotz der weiten Verbreitung beider Typen und der Tatsache, dass die einzelnen Gebiete, in denen sie registriert wurden, nicht verbunden waren, ist zu berücksichtigen, dass die meisten Exemplare aus der Zeit vom 9. bis zum 12. Jahrhundert stammen. Daraus lässt sich schließen, dass diese Ohrringe gerade in der mittelbyzantinischen Zeit sehr beliebt waren.

In Bezug auf die Funde aus Kroatien und Bosnien und Herzegowina ist zu sagen, dass sie in drei verschiedenen zeitlichen, aber kulturell unterschiedlichen Horizonten auftreten:

\section{Ohrringe vom Ende des 8. und aus der ersten Hälfte des 9. Jahrhunderts}

Die ältesten Ohrringe stammen aus der Zeit der Wende aus dem 8. ins 9. Jahrhundert. Es handelt sich dabei um zwei Exemplare mit einem spiralförmigen Anhänger aus den Gräbern 14 und 161 vom Fundort Gole Njive in Privlaka, die zweifellos der spä-

83 Etwas jüngeren Datums sind lediglich die Ohrringe des ersten Typs aus dem rumänischen Teil Dobrudschas und aus Bulgarien

84 Ausführlicher über mittelbyzantinischen Schmuck, siehe (Bollók 2010; Petrinec 2014). Über den mediterranen und byzantinischen Einfluss auf das Gebiet Mitteleuropas (siehe Daim 2000; Nowotny 2005; Eichert 2017; 2018). 


\section{Naušnice kasnog 9., 10. i ranog 11. stoljeća}

Ovoj skupini pripadaju naušnice s donjom polovinom karike, ukrašenom spiralnom viticom, iz Dvigrada u Istri, koje se dovode u vezu s ketlaškom kulturom. Tu pripisujem i naušnicu iz groba 89 uz Crkvu sv. Križa u Ninu te naušnice obaju tipova s vinodolskog Stranča i s groblja u Stombratama (Bijaći). Na ovim nedvojbeno starohrvatskim nekropolama pojavljuju se sporadični nalazi karakeristični za groblja s miješanim ketlaškim i bjelobrdskim nalazima u zapadnom dijelu Panonije. Istoj skupini pribrajaju se i zanimljiva groblja SZ Bosne s miješanim inventarom raznih kulutrnih skupina (Petoševci, Mahovljani), a vjerojatno i naušnice iz Plavnog i iz Zagreba.

\section{Naušnice druge polovine 10. i 11. stoljeća}

Ranom stupnju bjelobrdske kulture pripadaju i naušnice s Lijeve Bare u Vukovaru, iz Bijelog Brda i iz Osijeka. Sve se povezuju s bjelobrdskim nekropolama i datiraju u drugu polovinu 10. ili rano 11. stoljeće.

Kasnijoj bjelobrdskoj kulturi pripadaju naušnice s Mastirina u Kašiću i iz Stenjevca u Zagrebu, a možda i naušnica iz Galovca. Pripadaju vremenu druge polovine ili kraja 11. stoljeća. Istom vremenu pripisujem i tri para naušnica sa staklenim zrnima i viticama s Begovače u Biljanima Donjim s paralelama u srednjebizantskom nakitu Grčke. tawarischen Periode angehören. Das Gräberfeld, von dem sie herstammen, befindet sich an der südlichen Grenze des Awarischen Khaganats.

Anhand von Keramikfunden wird der Ohrring aus dem Wohnobjekt 096a am Fundort in Prečno Pole I in der Podravina innerhalb des frühmittelalterlichen Torčec in die Zeit vom Ende des 8. bis zur Mitte des 9. Jahrhunderts datiert. Dieses Gebiet befindet sich nicht innerhalb des Awarischen Khaganats und spätawarische Funde sind hier nur sporadisch. Es handelt sich wahrscheinlich um eine slawische Siedlung.

Auch Grab 162 neben der Kirche des Heiligen Kreuzes in Nin mit dem Fund eines Ohrrings mit spiralförmigem Anhänger, der in der Bestattungsschicht entdeckt wurde, die durch einen Goldsolid von Kaiser Konstantin V. Kopronim und seinem Sohn Leo IV datiert wurde, gehört in die letzten Jahrzehnte des 8 . oder die ersten Jahrzehnte des 9. Jahrhunderts. Im kulturellen Sinne ist es ein Horizont, der der Entstehungszeit des Kroatischen Fürstentums zugeordnet wird. Zum gleichen zeitlichen und kulturellen Horizont gehört der mit spiralförmigen Ranken verzierte Ohrring aus Grab 93 aus Ždrijac in Nin.

\section{Ohrringe aus dem späten 9., 10. und frühen 11. Jahrhundert}

Diese Gruppe umfasst die Ohrringe aus Dvigrad in Istrien, deren untere Ringhälften mit einer Spiralranke verziert sind und die mit der Köttlach-Kultur in Verbindung gebracht werden. Dieser Gruppe schreibe ich auch den Ohrring aus Grab 89 neben der Kirche des Heiligen Kreuzes in Nin zu, aber auch die Ohrringe beider Typen aus Stranče in Vinodol und vom Gräberfeld in Stombrate (Bijaći). Auf diesen zweifellos altkroatischen Nekropolen treten sporadische Funde auf, die für Gräberfelder mit gemischten Funden der Köttlach- und Bijelo Brdo- Kultur im westlichen Teil Pannoniens charakteristisch sind. Zur selben Gruppe gehören ebenfalls die interessanten Gräberfelder im Nordwesten Bosniens, die ein gemischtes Inventar unterschiedlicher kultureller Gruppen (Petoševci, Mahovljani) aufweisen, sowie wahrscheinlich auch die Ohrringe aus Plavno und Zagreb.

\section{Ohrringe aus der zweiten Hälfte des 10. und dem 11. Jahrhundert}

Zur frühen Stufe der Bijelo Brdo-Kultur gehören auch die Ohrringe vom Fundort Lijeva Bara in Vukovar, aus Bijelo Brdo und Osijek. Sie alle werden mit den Nekropolen der Bijelo Brdo-Kultur verbunden und datieren in die zweite Hälfte des 10. oder ins frühe 11. Jahrhundert.

Zur späteren Bijelo Brdo-Kultur zählen die Ohrringe aus Mastirine in Kašić und aus Stenjevec, aber möglicherweise auch die Ohrringe aus Galovac. Sie gehören in die zweite Hälfte oder an das Ende des 11. Jahrhunderts. Auch die drei Ohrringpaare mit Glaskörnern und Ranken aus Begovača in Biljane Donje, die Parallelen zu zentralbyzantinischem Schmuck aus Griechenland aufweisen, ordne ich der gleichen Zeit zu. 


\section{NAUŠNICE KOJIMA JE DONJA POLOVINA KARIKE OBAVIJENA VITICAMA OD SPIRALNO UVIJENE ŽICE}

\author{
1. DVIGRAD - KACAVANAC \\ a) Grob 43 \\ a. brončana naušnica kojoj je donja polovina karike ukrašena spiralno \\ uvijenom žicom; 2,6 × 2,7 cm; b. željezna pređica bubrežastog oblika; 3,9 \\ x 2,4 cm; c. željezni nožić; d. 10,2 cm, š. 2 cm. \\ Lit.: Marušić 1970, 27, T. III, 2-4.
}

b) Grob 47

a. brončana naušnica kojoj je donja polovina karike ukrašena viticama od spiralno uvijene žice; $2,9 \times 2,9 \mathrm{~cm}$; b. obična brončana karičica; 3,9 $x 3,6 \mathrm{~cm}$; c. brončana karičica s nataknutom perlom od bijele staklene paste; 3,6 $\times 4,2 \mathrm{~cm}$; d. brončana pređica četvrtastog oblika; 2,5 $\times 2,6 \mathrm{~cm}$. Lit.: Marušić 1970, 28, T. III, 7-10.

\section{STRANČE - GORICA Grob 179}

a. par brončanih naušnica kojima je donja polovina karike ukrašena viticama od spiralno uvijene žice; $3,8 \times 4,0 \mathrm{~cm}$.

Lit.: Cetinić 1998, 175, 217, T. 16, 1-2; 2011, 113, 176, T. LVII, 1-2.

\section{NIN - ŽDRIJAC Grob 93}

a. brončana naušnica kojoj je donja polovina karike ukrašena viticama od spiralno uvijene žice; $3,1 \times 2,3 \mathrm{~cm}$; b. obična bročana karičica; $2,5 \times 2,2$ cm; c. ulomak željeznog šila; d. 5,8 cm, deb. 0,6 cm.

Lit.: Belošević 2007, 86, 153, T. LVIII, 15-17.

\section{BISKUPIJA - CRKVINA Grobni nalaz nepoznatih okolnosti otkrića}

a. brončana karičica s donjom polovinom karike ukrašenom spiralno uvijenom žicom; $2,5 \times 2,3 \mathrm{~cm}$.

Lit.: Petrinec 2009, 71, 512, T. 236,4

\section{MAHOVLJANI - LUKA/KUŽNO GROBLJE Grob 3}

a. osam brončanih naušnica (4 para) s karikom povijenom u dvije petlje i jednom jagodom; pr. 3-3,2 cm; b. par brončanih karičica s dvije kukice; $3 \times 2,7 \mathrm{~cm}$; c. brončana naušnica s prema van izvijenom petljom; $3,7 \times$ $3,4 \mathrm{~cm}$; d. brončana karičica sa završetkom u obliku S- petlje; 3,2 × 3,5 cm; e. nepotpuna brončana lijevana naušnica s tri jagode; v. $2,5 \mathrm{~cm} ; \mathrm{f}$. fragment brončane naušnice $s$ donjom polovinom karike obavijenom spiralnom žicom; g. ogrlica od 162 staklene perle; h. donja polovina brončanoga dvodijelnog privjeska; v. $2,3 \mathrm{~cm}$; i. tri probušena rimska novca; j. četiri brončana prstena, jedan obični u obliku koluta i trokutastog presjeka (pr. $2,3 \mathrm{~cm}$ ) i tri istovjetna s krunom u obliku stepenaste piramide; pr. $2,2 \mathrm{~cm}, 2,0 \mathrm{~cm}, 1,9 \mathrm{~cm}$.

Lit.: Miletić 1979, 138, T. XII.
KATALOG 85

\section{OHRRINGE, DEREN UNTERE RINGHÄLFTE MIT RANKEN AUS SPIRALFÖRMIG GEWUNDENEM DRAHT UMWUNDEN IST}

\author{
1. DVIGRAD-KACAVANAC \\ a) Grab 43 \\ a. Bronzeohrring, deren untere Hälfte des Rings mit spiralförmig ge- \\ wundenem Draht verziert ist; $2,6 \times 2,7 \mathrm{~cm}$; b. nierenförmige Schnalle \\ aus Eisen; 3,9 × 2,4 cm; c. kleines Messer aus Eisen; Länge10,2 cm, Brei- \\ te $2 \mathrm{~cm}$ \\ Lit.: Marušić 1970, 27, T. III, 2-4.
}

b) Grab 47

a. Bronzeohrring, deren untere Ringhälfte mit Ranken aus spiralförmig gewundenem Draht verziert ist; $2,9 \times 2,9 \mathrm{~cm}$; b. einfaches Bronzeringlein; $3,9 \times 3,6 \mathrm{~cm} ; \mathrm{c}$. Bronzeringlein mit aufgesetzter Perle aus weiBer Glaspaste; 3,6 × 4,2 cm; d. viereckige Bronzeschnalle; 2,5 × 2,6 cm. Lit.: Marušić 1970, 28, T. III, 7-10.

\section{STRANČE-GORICA Grab 179}

a. Ein Paar Bronzeohrringe, deren unteren Ringhälften mit Ranken aus spiralförmig gewundenem Draht verziert sind; $3,8 \times 4,0 \mathrm{~cm}$. Lit.: Cetinić 1998, 175, 217, T. 16, 1-2; 2011, 113, 176, T. LVII, 1-2.

\section{NIN-ŽDRIJAC Grab 93}

a. Bronzeohrring, deren untere Ringhälfte mit Ranken aus spiralförmig gewundenem Draht verziert ist; $3,1 \times 2,3 \mathrm{~cm}$; b. einfaches Bronzeringlein; 2,5 X2,2 cm; c. Fragment eines Eisenpfriems; Länge 5,8 cm, Breite $0,6 \mathrm{~cm}$.

Lit.: Belošević 2007, 86, 153, T. LVIII, 15-17.

\section{BISKUPIJA-CRKVINA Grabfund mit unbekannten Entdeckungsum-} ständen

a. Bronzeringlein, deren untere Ringhälfte mit spiralförmig gewundenem Draht verziert ist; $2,5 \times 2,3 \mathrm{~cm}$.

Lit.: Petrinec 2009, 71, 512, T. 236,4

\section{MAHOVLJANI - LUKA/KUŽNO GROBLJE Grab 3}

a. acht Bronzeohrringe (4 Paare), deren Ringe in zwei Schleifen gewunden sind und eine Beere haben; Durchmesser $3-3,2 \mathrm{~cm}$; b. ein Paar Bronzeringlein mit zwei Haken; $3 \times 2,7 \mathrm{~cm}$; . Bronzeohrring mit nach außen gewundener Schleife; $3,7 \times 3,4 \mathrm{~cm}$; $d$. Bronzeringlein mit einem Ende in Form einer S-Schleife; 3,2 × 3,5; e. unvollständiger gegossener Bronzeohrring mit drei Beeren; Größe 2,5 cm; f. Fragment eines Bronzeohrrings, dessen untere Ringhälfte mit spiralförmigen Draht umwunden ist; g. Halskette aus 162 Glasperlen; h. untere Hälfte eines zweiteiligen Bronzeanhängers; Größe $2,3 \mathrm{~cm}$; i. drei durchbrochene römische Münzen; j. vier Bronzeringe, ein einfacher Ring in Form eines Reifs und mit dreieckigem Querschnitt (Durchmesser 2,3 cm) und drei identische mit Krone in Form einer Stufenpyramide; Durchmesser $2,2 \mathrm{~cm}, 2,0 \mathrm{~cm}, 1,9 \mathrm{~cm}$.

Lit.: Miletić 1979, 138, T. XII.
85 Crteže je načinila Silvana Juraga, dokumentaristica Muzeja hrvatskih arheoloških spomenika prema objavama u literaturi navedenoj u kataloškim jedinicima. Podaci o dimenzijama također su preuzeti iz literature te nisu ujednače-
85 Die Zeichnungen wurden von Silvana Juraga erstellt, der Dokumentaristin des Museums der kroatischen archäologischen Denkmäler gemäß den Veröffentlichungen in der Literatur, die in den Katalogeinheiten angegeben ist. Die Größenangaben sind ebenfalls aus der Literatur übernommen und demnach nicht einheitlich. 


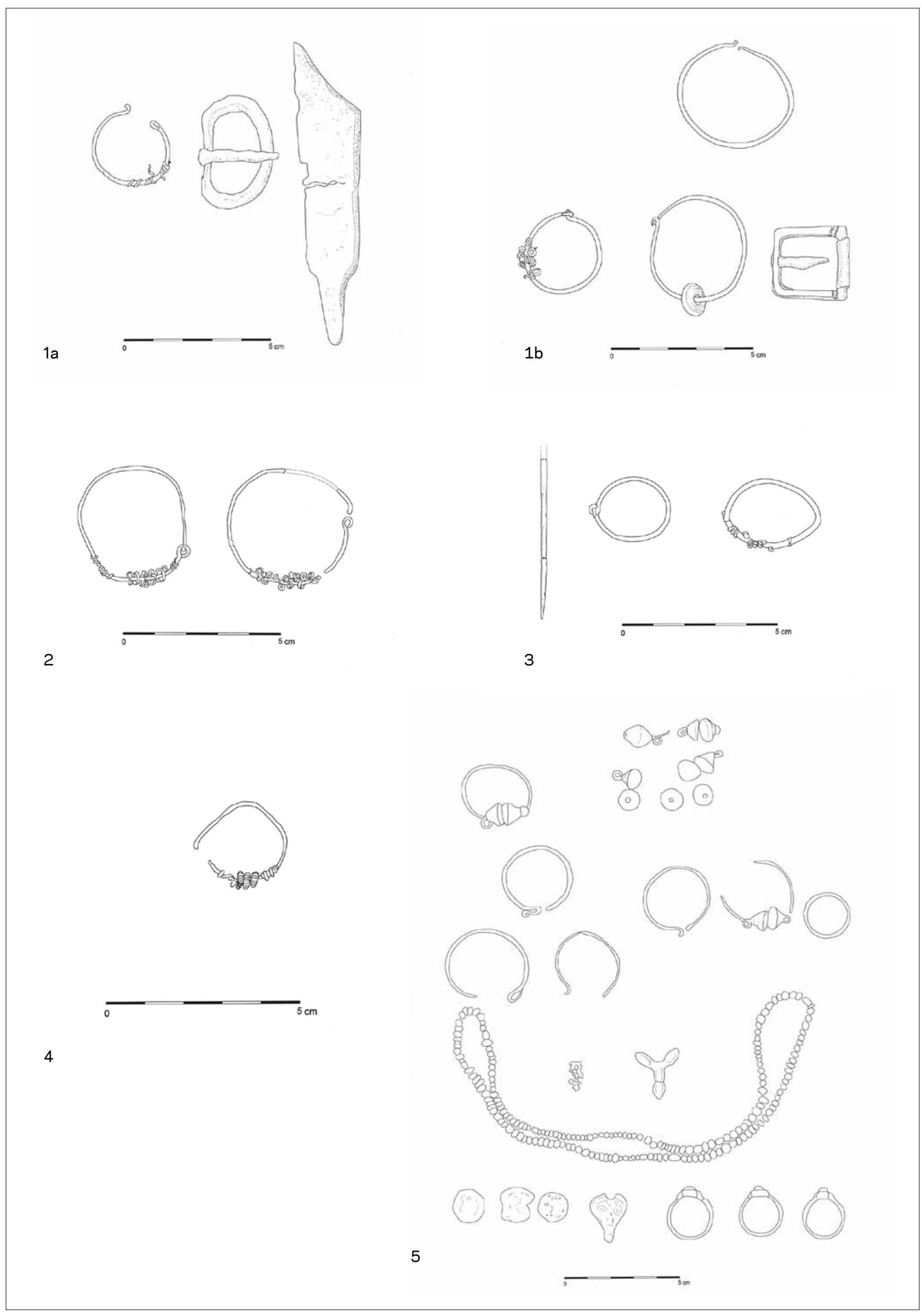



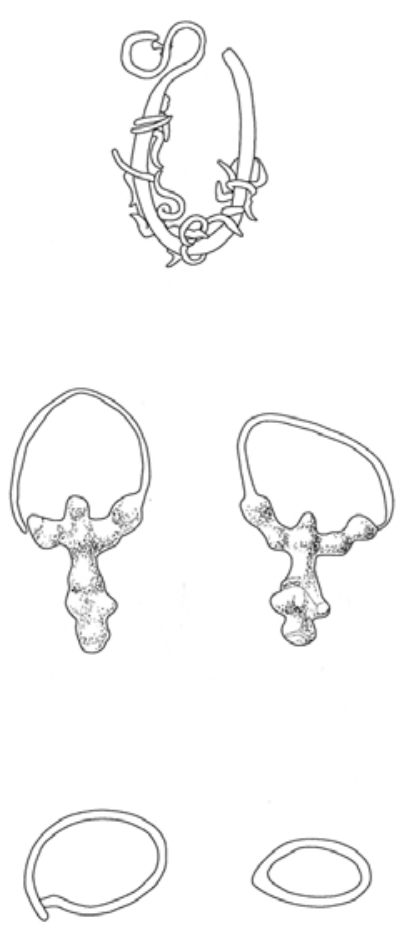

6
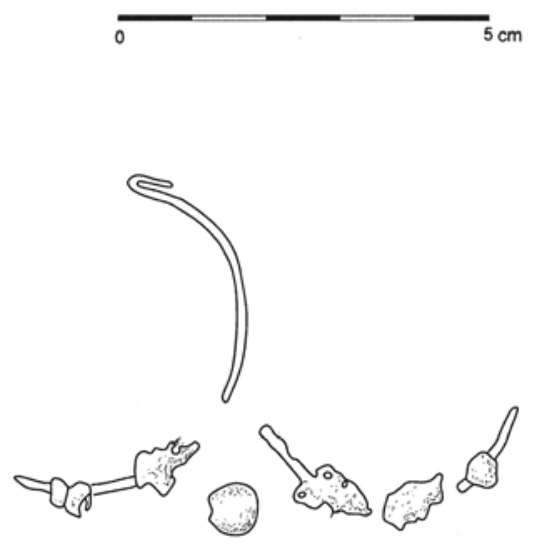

$10 a$
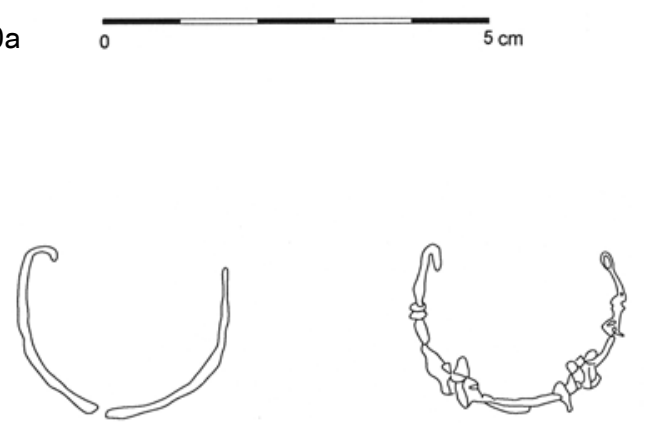

$10 c$

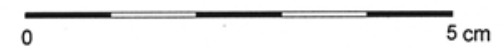

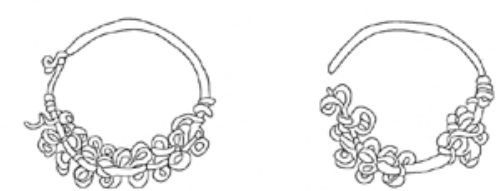

7
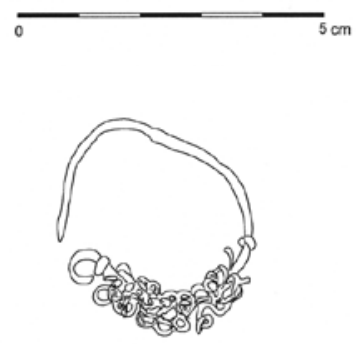

8
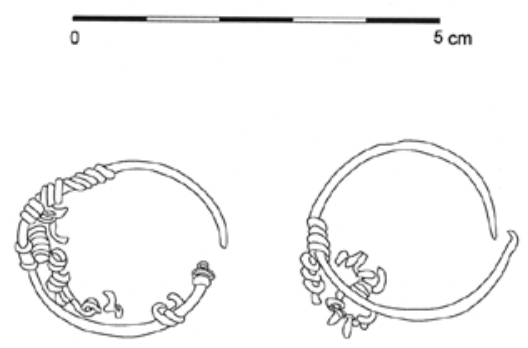

9
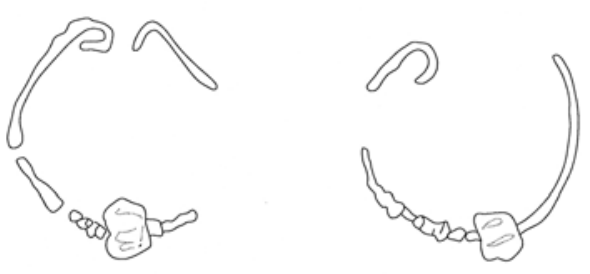

$10 b$
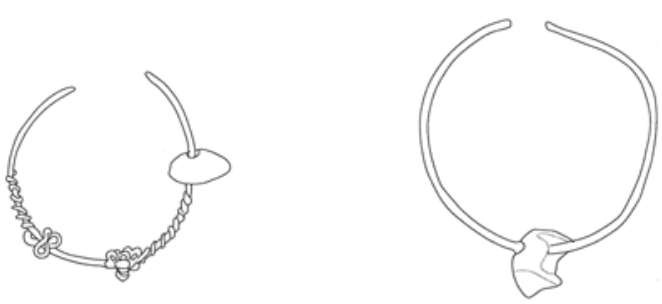

11

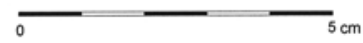




\section{ZAGREB - STENJEVEC Grob 155}

a. brončana naušnica $S$ donjom polovinom karike ukrašenom spiralnim viticama i završetkom u obliku raskovane S-petlje; pr. 1,7 cm; b. par brončanih lijevanih grozdolikih naušnica s četiri koljenca na karici; v. $3,6 \mathrm{~cm}$; c. brončana karičica rastavljenih krajeva sa završetkom u obliku S-petlje; pr. 2 cm; d. brončana karičica okruglog presjeka i ravno odrezanih krajeva; pr. 1,6 cm.

Lit.: Simoni 2004, 43, kat. br. 35.

\section{KAŠIĆ - MASTIRINE Grob 66}

a. par srebrnih naušnica s donjom polovinom karike ukrašenom viticama od spiralno uvijene žice; pr. $2,7 \mathrm{~cm}$.

Lit.: Jelovina 1982, 44-45, T. IV, 66.

\section{GALOVAC - CRKVINA Nalaz izvan groba}

a. srebrna naušnica $s$ donjom polovinom karike ukrašenom viticama od spiralno uvijene žice; $3,0 \times 2,5 \mathrm{~cm}$.

Lit.: Belošević 1993, T. XXIV, 1.

\section{9. ŽUPČA Nepoznate okolnosti otkrića}

a. par srebrnih naušnica s donjom polovinom karike ukrašenom viticama od spiralno uvijene žice.

Lit.: Miletić 1975, 98-99, T. III, 8.

\section{BILJANE DONJE - BEGOVAČA}

a) Grob 202

a. par veoma fragmentiranih brončanih naušnica s nataknutom staklenom perlom crvenkastosmeđe boje; karika je u donjoj polovini ukrašena viticama od spiralno uvijene žice.

Lit.: Jelovina, Vrsalović 1981, 80, T. X, 202.

b) Grob 231

a. par brončanih naušnica s nataknutom staklenom perlom žuto-zelene boje; karika je u donjoj polovini ukrašena viticama od spiralno uvijene žice; pr. $2,8 \mathrm{~cm}$

Lit.: Jelovina, Vrsalović 1981, 81, T. XII, 231.

\section{c) Grob 256}

a. par fragmentiranih brončanih naušnica s nataknutom staklenom perlom (sačuvana je samo na jednoj naušnici, a tamnosmeđe je boje); karika je u donjoj polovini ukrašena viticama od spiralno uvijene žice; pr. $2,5 \mathrm{~cm}$.

Lit.: Jelovina, Vrsalović 1981, 83, T. XV, 256.

\section{BIJAĆ - STOMBRATE Grob 33}

a. par veoma oštećenih brončanih naušnica s jagodama i karikom ukrašenom viticama od spiralno uvijene žice; pr. karika $3,5 \mathrm{~cm} ; 3,8 \mathrm{~cm}$.

Lit.: Kamenjarin 2009, 90, 103, T. VI, 6-7.

\section{ZAGREB - STENJEVEC Grab 155}

a. Bronzeohrring, dessen untere Ringhälfte mit spiralförmigen Ranken verziert ist und der ein Ende in Form einer geschmiedeten SSchleife hat; Durchmesser $1,7 \mathrm{~cm}$; b. ein Paar gegossener traubenför miger Bronzeohrringe mit vier knieförmigen Verdickungen am Ring lein; Größe 3,6 cm; c. Bronzeringlein mit aufgetrennten Enden in Form einer S-Schleife; Durchmesser $2 \mathrm{~cm}$; d. Bronzeringlein mit rundem Querschnitt und gerade geschnittenen Enden; Durchmesser 1,6 cm. Lit.: Simoni 2004, 43, Kat. Nr. 35.

\section{KAŠIĆ-MASTIRINE Grab 66}

a. ein Paar Silberohrringe, deren untere Ringhälften mit Ranken aus spiralförmig gewundenem Draht verziert sind; Durchmesser $2,7 \mathrm{~cm}$. Lit.: Jelovina 1982, 44-45, T. IV, 66.

\section{GALOVAC-CRKVINA Fund außerhalb des Grabes}

a. Silberohrring, dessen untere Ringhälfte mit Ranken aus spiralförmig gewundenem Draht verziert ist; $3,0 \times 2,5 \mathrm{~cm}$.

Lit.: Belošević 1993, T. XXIV, 1.

\section{9. ŽUPČA unbekannte Entdeckungsumstände}

a. ein Paar Silberohrringe, deren untere Ringhälften mit Ranken aus spiralförmig gewundenem Draht verziert sind.

Lit.: Miletić 1975, 98-99, T. III, 8.

\section{BILJANE DONJE-BEGOVAČA}

a) Grab 202

a. ein Paar sehr fragmentierter Bronzeohrringe mit aufgesetzter rotbrauner Perle; der Ring ist in der unteren Hälfte mit Ranken aus spiralförmig gewundenem Draht verziert.

Lit.: Jelovina, Vrsalović 1981, 80, T. X, 202.

b) Grab 231

a. ein Paar Bronzeohrringe mit aufgesetzter gelbgrüner Glasperle; der Ring ist in der unteren Hälfte mit Ranken aus spiralförmig gewundenem Draht verziert; Durchmesser 2,8 cm

Lit.: Jelovina, Vrsalović 1981, 81, T. XII, 231.

c) Grab 256

a. ein Paar fragmentierter Bronzeohrringe mit aufgesetzter Glasperle (nur auf einem Ohrring in dunkelbrauner Farbe erhalten); der Ring ist in der unteren Hälfte mit Ranken aus spiralförmig gewundenem Draht verziert; Durchmesser $2,5 \mathrm{~cm}$.

Lit.: Jelovina, Vrsalović 1981, 83, T. XV, 256.

\section{BIJAĆI - STOMBRATE Grab 33}

a. ein Paar stark beschädigter Bronzeohrringe mit Beeren und Ring, der mit Ranken aus spiralförmig gewundenem Draht verziert ist; Durchmesser des Rings $3,5 \mathrm{~cm} ; 3,8 \mathrm{~cm}$.

Lit.: Kamenjarin 2009, 90, 103, T. VI, 6-7. 


\section{NAUŠNICE S UKRASOM U OBLIKU SPIRALNOG STOŠCA}

\section{PRIVLAKA - GOLE NJIVE}

a) Grob 14

a. brončana naušnica sa spiralnim privjeskom; $2,0 \times 1,5 \mathrm{~cm}$

Lit.: neobjavljeno (podaci preuzeti iz rada nastalog u sklopu poslijediplomskoga doktorskog studija; Šmalcelj Novaković 2015)

\section{b) Grob 161}

a. brončana naušnica sa spiralnim privjeskom; $2,0 \times 1,6 \mathrm{~cm}$; b. brončana fragmentirana karičica s ostatkom metalnog privjeska na donjem luku karike; 2 × 1,6 cm

Lit.: neobjavljeno (podaci preuzeti iz rada nastalog u sklopu poslijediplomskoga doktorskog studija; Šmalcelj Novaković 2015).

\section{PREČNO - POLE I (TORČEC)}

Stambeni objekt SJog6a

a. fragmentirana brončana naušnica sa spiralnim privjeskom; v. cca 2,0 $\mathrm{cm}$

Lit.: Sekelj Ivančan 2010, 140-141, 257, T. 37, 230.

\section{ZAGREB - KAPTOL (KATEDRALA) Grobni nalaz nepoznatih okolnosti otkrića}

a. brončana naušnica sa spiralnim privjeskom; 2,6 x 1,9 cm

Lit.: Demo 2007, 23-25, sl. 23/24, K2.

\section{PETOŠEVCI - BAGRUŠA Grob 12}

a. brončana naušnica sa spiralnim privjeskom; 3,0 x 1,5 cm; b. brončani uzdužno kanelirani prsten; pr. $1,7 \mathrm{~cm}$

Lit.: Žeravica 1986, 134, T. II, 19-20.

\section{STRANČE - GORICA Grob 5}

a. nepotpuna brončana naušnica sa spiralnim privjeskom; duž. 1,7 cm; b. par brončanih karičica od tanke žice i sa završecima u obliku petlje i kvačice; pr. 4 cm.

Lit.: Cetinić 1998, 177, 219, T. 18, 4-6; 2011, 44, 121, T. II, 2-4.

\section{NIN - SV. KRIŽ}

a) Grob 89

a. brončana karičica s nepotpunim spiralnim privjeskom; pr. $1,5 \mathrm{~cm}$; b. par veoma oštećenih srebrnih karičica kružnog presjeka; pr. cca 2,0 cm; c. masivni srebrni prsten; pr. 2,2 cm

Lit.: Belošević 1998, 122, T. XIX, 12-15; T. XXII, 4-5, T. XXIII, 3, 6.

b) Grob 162

a. brončana naušnica sa spiralnim privjeskom; pr. 1,9 cm, duž. privjeska $1,5 \mathrm{~cm}$; b. par brončanih karičica sa završetkom u obliku petlje izvijene prema van i kvačice; pr. oko $2 \mathrm{~cm}$; c. veoma oštećena brončana naušnica s karikom povijenom u petlje; $d$. oštećeni prsten od brončanoga lima; pr. oko 2,3 cm; e. ogrlica sastavljena od staklenih zrna žute, plave i zelene boje, dvaju zrna s bijelom valovnicom, ulomka oboda rimske staklene posude $\mathrm{i}$ jedne rimske perle.

Lit.: Belošević 1998, 131, T. XX, 12-17.

\section{OHRRINGE MIT VERZIERUNG \\ IN FORM EINES SPIRALFÖRMIGEN KEGELS}

\author{
12. PRIVLAKA - GOLE NJIVE \\ a) Grab 14 \\ a. Bronzeohrring mit spiralförmigem Anhänger; $2,0 \times 1,5 \mathrm{~cm}$.
}

Lit.: unveröffentlicht (Angaben wurden aus der Arbeit übernommen, die im Rahmen der Doktorarbeit entstand; Šmalcelj Novaković 2015.)

b) Grab 161

a. Bronzeohrring mit spiralförmigem Anhänger; 2,0 x 1,6 cm; b. fragmentiertes Bronzeringlein mit Resten eines Metallanhängers am unteren Ringbogen; 2 x 1,6 cm.

Lit.: unveröffentlicht (Angaben wurden aus der Arbeit übernommen, die im Rahmen der Doktorarbeit entstand; Šmalcelj Novaković 2015.)

\section{PREČNO-POLE I (TORČEC)}

Wohnobjekt SJog6a

a. fragmentierter Bronzeohrring mit spiralförmigem Anhänger; Größe ca. $2,0 \mathrm{~cm}$

Lit.: Sekelj Ivančan 2010, 140-141, 257, T. 37, 230.

\section{ZAGREB-KAPTOL (KATHEDRALE) Grabfund mit unbekannten} Entdeckungsumständen

a. Bronzeohrring mit spiralförmigem Anhänger; 2,6 x 1,9 cm.

Lit.: Demo 2007, 23-25, 23/24, K2.

\section{PETOŠEVCI - BAGRUŠA Grab 12}

a. Bronzeohrring mit spiralförmigem Anhänger; 3,0 x 1,5 cm b. Bronzering, der längsseitig kanneliert ist; Durchmesser $1,7 \mathrm{~cm}$

Lit.: Žeravica 1986, 134, T. II, 19-20.

\section{STRANČE - GORICA Grab 5}

a. unvollständiger Bronzeohrring mit spiralförmigem Anhänger; Länge $1,7 \mathrm{~cm}$; b. ein Paar Bronzeringlein aus dünnem Draht mit Enden in Form einer Schleife und eines Häkchens; Durchmesser $4 \mathrm{~cm}$.

Lit.: Cetinić 1998, 177, 219, T. 18, 4-6; 2011, 44, 121, T. II, 2-4.

\section{NIN - SV. KRIŽ}

a) Grab 89

a. Bronzeringlein mit unvollständigem spiralförmigen Anhänger; Durchmesser $1,5 \mathrm{~cm}$; b. ein Paar stark beschädigter Silberringlein mit kreisförmigem Querschnitt; Durchmesser ca. 2,0 cm; c. massiver Silberring; Durchmesser $2,2 \mathrm{~cm}$.

Lit.: Belošević 1998, 122, T. XIX, 12-15; T. XXII, 4-5, T. XXIII, 3, 6.

\section{b) Grab 162}

a. Bronzeohrring mit spiralförmigem Anhänger; Durchmesser 1,9 cm, Länge des Anhängers $1,5 \mathrm{~cm}$; b. ein Paar Bronzeringlein mit Ende in Form einer nach außen gewundenen Schleife und einem Häkchen; Durchmesser ca. $2 \mathrm{~cm}$; c. ein stark beschädigter Bronzeohrring mit einem in eine Schleife gewundenen Ring; d. beschädigter Ring aus Bronzeblech; Durchmesser ca. 2,3 cm; e. Halskette, die aus gelben, blauen und grünen Glaskörnern, zwei Körnern mit weißen Wellen, einem Bruchstück vom Kranz eines römischen Glasgefäßes und einer römischen Perle zusammengesetzt ist.

Lit.: Belošević 1998, 131, T. XX, 12-17. 


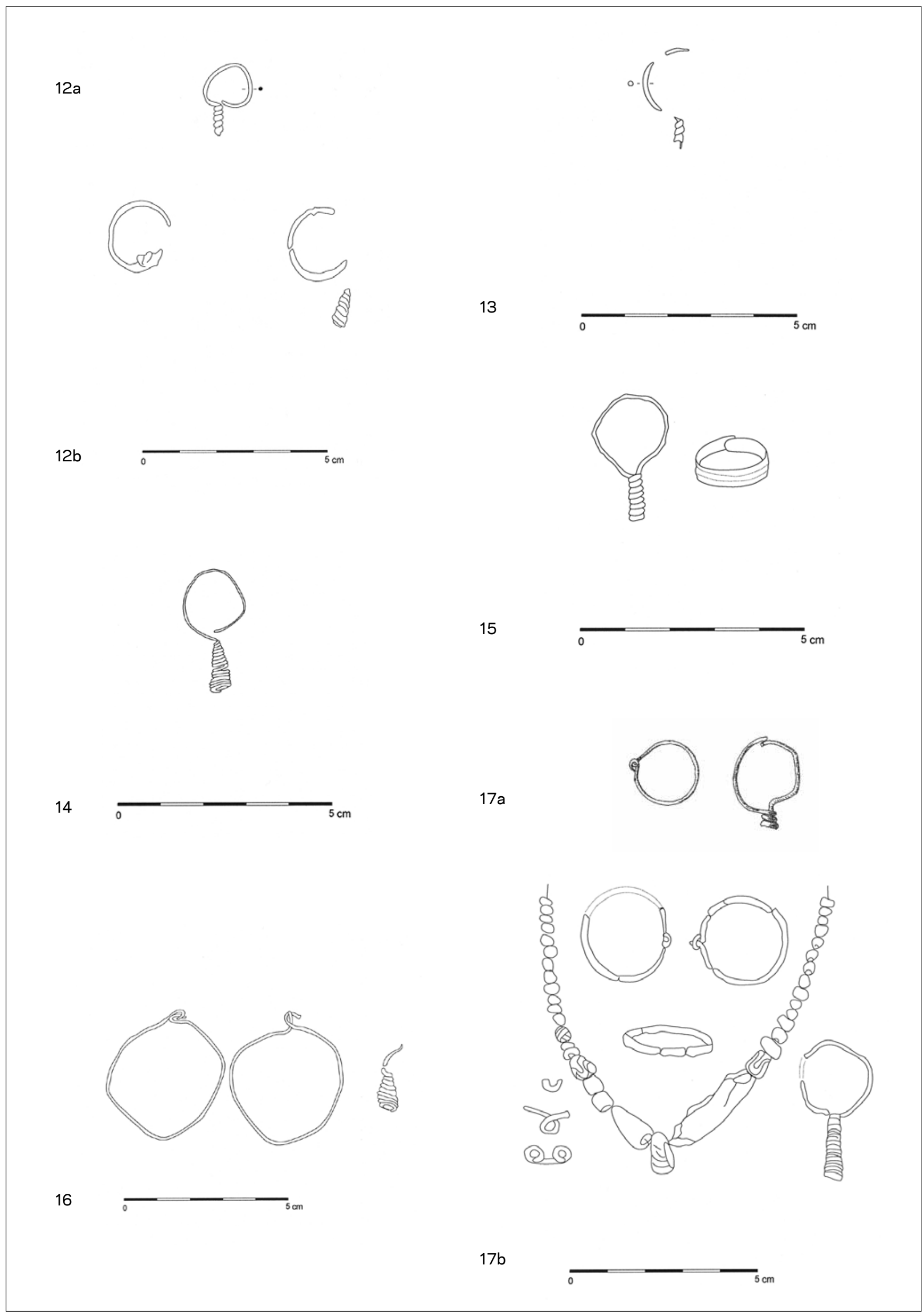



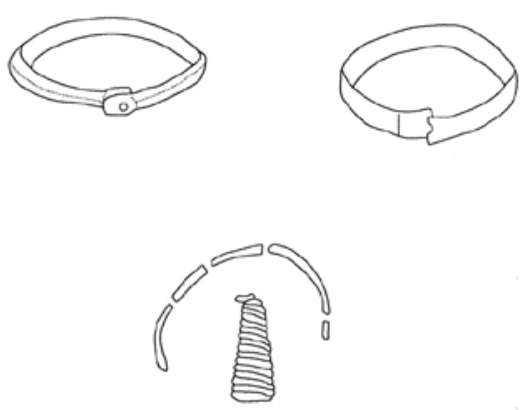

18
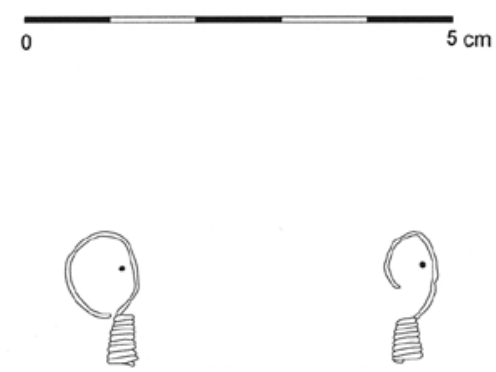

20
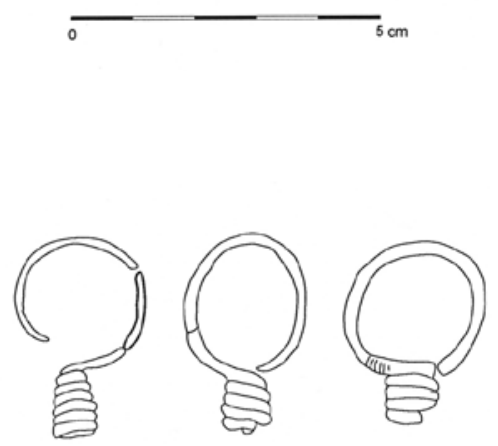

$21 b$

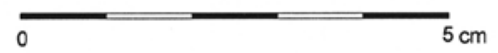

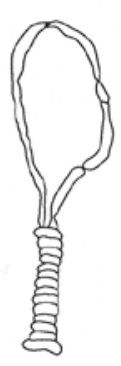

19
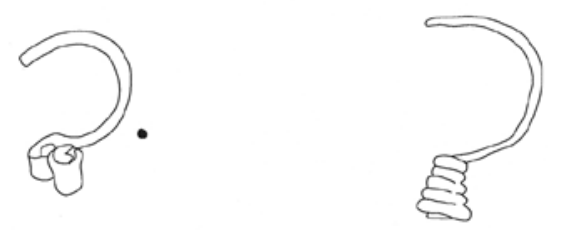

$21 a$

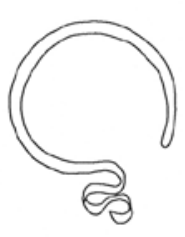

22
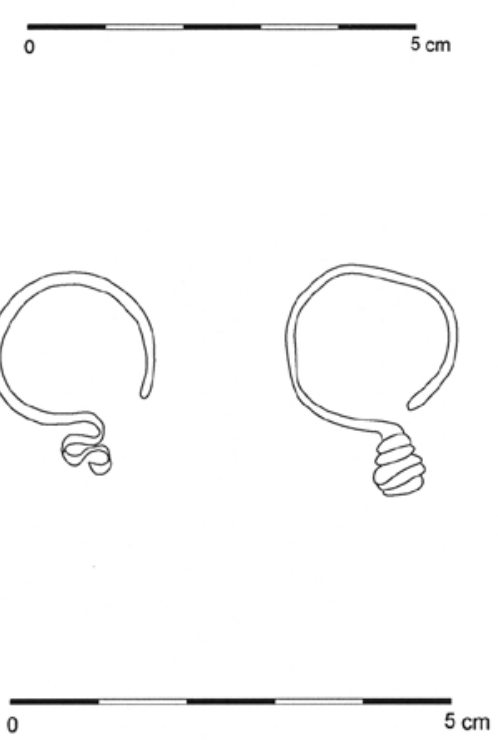


\section{BIJAĆI - STOMBRATE Grob 30}

a. brončana naušnica sa spiralnim privjeskom; $2,1 \times 1,6 \mathrm{~cm}$; b. srebrni prsten preklopljenih i zakovicom spojenih krajeva; pr. $2,3 \mathrm{~cm}$; c. brončani prsten preklopljenih krajeva; pr. 2,1 cm.

Lit.: Kamenjarin 2009, 90, T. VI, 3-5.

19. PLAVNO - MEĐINE (ĐURIĆA GROBLJE) Grobni nalaz nepoznatih okolnosti otkrića

a. brončana naušnica sa spiralnim privjeskom; $3,7 \times 1,0 \mathrm{~cm}$.

Lit.: Petrinec 2009, 92, 568, T. 290, 5.

\section{VUKOVAR - LIJEVA BARA Grob 252}

a. par brončanih naušnica sa spiralnim privjeskom; $2,5 \times 1,3 \mathrm{~cm} ; 2,5 \times$ 0,98 ; b. ogrlica od staklenih perli i metalnih privjesaka (rimski novac, latenska fibula).

Lit.: Demo 2009, 231-233.

\section{BIJELO BRDO II (ul. Venecija)}

a) Grob 221 (istraživanja 1907. god.) ${ }^{86}$

a. brončana naušnica sa spiralnim privjeskom; v. 2,3 cm; b. brončana karičica sa završetkom u obliku raskovane S-petlje; pr. 1,5 cm.

Lit.: Ercegović 1958, 168, 174, sl. 31-32.

b) Grobni nalazi nepoznatih okolnosti otkrića (istraživanja 1895. do 1897.)

a. brončana naušnica s ukrasom u obliku spiralnog stošca; $2,3 \times 1,5 \mathrm{~cm}$; b. brončana naušnica $s$ valjkastim ukrasom od spiralne žice; $2,2 \times 1,2$ $\mathrm{cm}$; c. brončana naušnica s valjkastim ukrasom od spiralne žice; $2,1 \mathrm{x}$ $1,7 \mathrm{~cm}$.

Lit.: Brunšmid 1904, 38, sl. 6, 22-24, 39.

\section{OSIJEK - VIJENAC IVANA MEŠTROVIĆA}

\section{Nalaz nepoznatih okolnosti otkrića}

a. brončana naušnica sa spiralnim privjeskom; 2,0 x 0,1 cm; b. brončana karičica sa završetkom u obliku raskovane S-petlje; $1,8 \times 0,15 \mathrm{~cm}$.

Lit.: Bulat 1968, 12, T. I, 1-2.

\section{BIJAĆI - STOMBRATE Grab 30}

a. Bronzeohrring mit spiralförmigem Anhänger; $2,1 \times 1,6 \mathrm{~cm}$; b. Silberring mit überlappenden und mit Niete verbundenen Enden; Durch messer 2,3 cm; c. Bronzering mit überlappenden Enden; Durchmesser $2,1 \mathrm{~cm}$.

Lit.: Kamenjarin 2009, S. 90, T. VI, 3-5.

\section{PLAVNO - MEĐINE (ĐURIĆA GROBLJE) Grabfund mit unbekannten} Entdeckungsumständen

a. Bronzeohrring mit spiralförmigem Anhänger; $3,7 \times 1,0 \mathrm{~cm}$

Lit.: Petrinec 2009, S. 92, S. 568, T. 290, 5

\section{VUKOVAR - LIJEVA BARA Grab 252}

a. ein Paar Bronzeohrringe mit spiralförmigem Anhänger; $2,5 \times 1,3 \mathrm{~cm}$ $2,5 \times 0,98$; b. Halskette aus Glasperlen und Metallanhängern (römischen Münzen, La-Tène Fibel).

Lit.: Demo 2009, S. 231-233.

\section{BIJELO BRDO II (Straße Venedig)}

a) Grab 221 (Forschungen im Jahr 1907)

a. Bronzeohrring mit spiralförmigem Anhänger; Größe 2,3 cm; b. Bronzeringlein mit einem Ende in Form einer geschmiedeten S-Schleife; Durchmesser $1,5 \mathrm{~cm}$.

Lit.: Ercegović 1958, S. 168, S. 174, Abb. 31-32.

b) Grabfunde mit unbekannten Entdeckungsumständen (Forschungen von 1895 bis 1897)

a. Bronzeohrring mit Verzierung in Form eines spiralförmigen Kegels; $2,3 \times 1,5 \mathrm{~cm}$; b. Bronzeohrring mit walzenförmiger Verzierung aus spiral gewundenem Draht; 2,2 x 1,2 cm; c. Bronzeohrring mit walzenförmiger Verzierung aus spiral gewundenem Draht; $2,1 \times 1,7 \mathrm{~cm}$.

Lit.: Brunšmid 1904, S. 38, Abb. 6, 22-24, S. 39

22. OSIJEK - VIJENAC IVANA MEŠTROVIĆA Fund mit unbekannten Entdeckungsumständen

a. Bronzeohrring mit spiralförmigem Anhänger; $2,0 \times 0,1 \mathrm{~cm}$; b. Bron zeringlein mit einem Ende in Form einer geschmiedeten S-Schleife; $1,8 \times 0,15 \mathrm{~cm}$.

Lit.: Bulat 1968, 12, T. I, 1-2.
86 Na groblju je ukupno pronađeno 13 primjeraka u 7 grobova, ali nisu sve publicirane (usp. Demo 2009, 449).
86 Auf dem Gräberfeld wurden insgesamt 13 Exemplare in 7 Gräbern ent deckt, jedoch sind nicht alle publiziert (vgl. Demo 2009, 449). 


\section{BIBLIOGRAFIJA LITERATUR}

Albani 2010 - J. Albani, Elegance Over the Borders, The Evidence of Middle Byzantine Earrings, in Entwistle, C., Adams, N. (eds.), 'Intelligible Beauty': Recent Research on Byzantine Jewellery, British Museum Research Publications 178, The British Museum, 2010, 193-202.

Antonaras 2012 - A. C. Antonaras, Middle and Late Byzantine Jewellery from Thessaloniki and its Region, in Böhlendorf-Arslan, B., Ricci, A. (eds.), Byzantine Small Finds in Archaeological Contexts, Byzas 15, Ege Yayinlari, 2012, $117-126$.

Aspetsberger, Eichert 2016 - A. Aspetsberger, S. Eichert, Frühmittelalterlich Grabfunde aus Franzhausen, Niederösterreich, Fundberichte aus Österreich $55,2016,125-139$

Бајаловић - Хаџи-Пешић 1984 - М. Бајаловић - Хаџи-Пешић, Накит VIII - XVIII века у Музеју града Београда, Музеј града Београда, 1984

Барачки 1977 - С. Барачки, Југоисточни Банат у раном средњем веку са прегледом раносредњовековних налазишта, Народни музеј Вршац, 1977.

Belošević 1980 - J. Belošević, Materijalna kultura Hrvata od 7. do 9. stoljeća, Sveučilišna naklada Liber, 1980.

Belošević 1993 - J. Belošević, Ishodi pete, završne kampanje istraživanja lokaliteta Crkvina u Galovcu kod Zadra, Radovi Filozofskog fakulteta u Zadru 31/18, 1993, 121-142.

Belošević 1998 - J. Belošević, Srednjovjekovno groblje u okolišu crkve Sv. Križa u Ninu, Radovi Filozofskog fakulteta u Zadru 37/24, 1998, 105-154.

Belošević 2007 - J. Belošević, Starohrvatsko groblje na Ždrijacu u Ninu, ArheoIoški muzej Zadar, 2007.

Bikić 2010 - V. Bikić, Vizantijski nakit u Srbiji, Posebna izdanja 48, Arheološki institut Beograd, 2010

Bilogrivić 2016 - G. Bilogrivić, Etnički identiteti u ranosrednjovjekovnoj Hrvatskoj - materijalni i pisani izvori, unpublished PhD thesis, Filozofski fakultet Sveučilišta u Zagrebu, 2016.

Bilogrivić 2019 - G. Bilogrivić, Medieval Reality or a Modern Construct? Old Croatian Culture in Medieval Studies Between the 19th and 21st Century, SüdostForschungen 78, 2019, 191-225.

Bollók 2010 - Á. Bollók, Byzantine Jewellery of the Hungarian conquest Period: a View from the Balkans, in Entwistle, C., Adams, N. (eds.), 'Intelligible Beauty': Recent Research on Byzantine Jewellery, British Museum Research Publications 178, The British Museum, 2010, 179-190.

Brunšmid 1904 - J. Brunšmid, , Hrvatske sredovječne starine, Vjesnik hrvatskog arkeologičkog društva 7, 1904, 30-97.

Bulat 1968 - M. Bulat, Neki nalazi ranog srednjeg vijeka iz Osijeka, Starohrvatska prosvjeta 10, 1968, 11-21.

Cetinić 1998 - Ž. Cetinić, Stranče - Gorica starohrvatsko groblje, Pomorski i povijesni muzej Hrvatskog primorja Rijeka, 1998.

Cetinić 2011 - Ž. Cetinić, Stranče - Vinodol, Starohrvatsko groblje na Gorici, Pomorski i povijesni muzej Hrvatskog primorja, 2011.

Curta 2001 - F. Curta, The Making of the Slavs, History and Archeology of Lower Danube Region, s. 500-700, Cambridge University Press, 2001.

Curta 2010 - F. Curta, Etnicitet u ranosrednjovjekovnoj arheologiji: Primjer ranoslavenskih nalaza u jadranskog regiji, Starohrvatska prosvjeta 37, 17-50.

Čilinská 1975 - Z. Čilinská, Frauenschmuck aus dem 7.-8. Jahrhundert im Karpatenbecken, Slovenská archeológia 23, 1975, 63-96

Dadić 2020 - M. Dadić, Starohrvatski grobovi otkriveni na položaju Banovac u Ninu, s osvrtom na ostale srednjovjekovne grobove/ Early Croatian graves from the Banovac site in Nin, with reference on other medieval graves, Diadora $33-34,2020,359-380$

Daim 2000 - F. Daim, "Byzantinische" Gürtelgarnituren des 8. Jahrhunderts, in Daim, F. (ed.), Die Awaren am Rand der byzantinischen Welt, Studien zu Diplomatie, Handel und Technologietransfer im Frühmittelalter, Monographien aus Frühgeschichte und Mittelalterarchäologie 7, Universitätsverlag Wagner, 2000.
Demo 1996, Vukovar - Lijeva bara, Arheološki muzej u Zagrebu, 1996.

Demo 2007 - Ž. Demo, Opatovina, tragovi povijesti izgubljene u sadašnjosti, Arheološki muzej u Zagrebu, 2007

Demo 2009 - Ž. Demo, Ranosrednjovjekovno groblje bjelobrdske kulture: Vuko var - Lijeva Bara (X.-XI. stoljeće) / An Early Medieval Cemetery of the Bijelo Brdo Culture: VukovarLijeva - Bara (10th - 11th Centuries), Katalozi i monografije Arheološkog muzeja u Zagrebu 6/1-2, Arheološki muzej u Zagrebu, 2009.

Džino 2008 - D. Džino, „Becoming Slav“, Becoming Croat“, New approaches in the research of identities in post-Roman Illyricum, Hortus Artium Medievalum $14,2008,195-206$

Džino 2009 - D. Džino, Novi pristup izučavanju ranog hrvatskog identiteta, $R a$ dovi zavoda za hrvatsku povijest 41, 2009, 33-54

Džino 2018 - D. Džino, Starokršćanski bazilikalni kompleks i grobovi u tumulima u Ljupču: Odgonetanje „mračnog“ doba Dalmacije, Starohrvatska prosvjeta 44-45, 2018, 89-113.

Džino 2021a - D. Džino, Rethinking Periodization in Post-Roman Southeastern Europe: the Case-Study of Dalmatia, Archeologia Bulgarica 25/1, 2021, 55-76.

Džino 2021b - D. Džino, From Justinian to Branimir, The Making of the Middle Age sin Dalmatia, Routledge Taylor\&Francis Group, 2021.

Ђуровић 2012 - И. Ђуровић, Средњевековни накит из збирки Народног музеја Крагујевац, Народни музеј Крагујевац, 2012.

Eichert 2010 - S. Eichert, Die frühmittelalterliche Grabfunde Kärntens. Die ma terielle Kultur Karantaniens anhand der Grabfunde vom ende der Spätantike bis ins 11. Jahrhundert, Klagenfurt am Wörthersee Verl. des Geschichtsvereines für Kärnten, 2010.

Eichert 2013 - S. Eichert, Zur Absolutchronologie des Ostenalpenraums, Bericht der Bayerischen Bodendenkmalpflege 54, 2013, 425-426.

Eichert 2017 - S. Eichert, Der frühmittelalterliche Ostalpenraum und die mediterrane Welt, Zur Rezeption mediterraner Vorbilder für die Motivik frühmittelalterlicher Emailscheibenfibel, in Dörfler, I., Gleirscher, P., Ladstätter, S., Pucker, I. (eds.), Ad Amussim: Festschrift zum 65. Geburtstag von Franz Gla ser, Kärntner Museumsschriften 85, Verlag des Landesmuseums für Kärnten; Österreichisches Archäologisches Institut an der Österreichischen Akademie der Wissenschaften, 2007, 301-323.

Eichert 2018 - S. Eichert, Griffons and Birds, Mediterranean Morifs on early medieval enamelled disc Brooches in Central Europe, in Drauschke, J., Kislinger, E., Kühtreiber, K, Kühtreiber, T., Scharrer-Liška, G., Vida, T. (eds.) Lebenswelten zwischen Archäologie und Geschichte, Festschrift für Falko Daim zu seinem 65 Geburtstag, Monographien des Römisch-Germanischen Zentralmuseums 150 Verlag des Römisch-Germanischen Zentralmuseums ,2018, 113-122.

Ercegović 1958 - S. Ercegović, Neobjavljeni grobni nalazi iz Bijelog Brda, Sta rohrvatska prosvjeta $6,1958,165-184$

Ercegović-Pavlović 1980 - S. Ercegović-Pavlović, Les nécropoles romaines et médiévales de Mačvanska Mitrovica, Sirmium 12, Arheološki institut u Beogradu, 1980

Fiedler 1992 - U. Fiedler, Studien zu Gräberfeldern des 6. bis 9. Jahrhunderts an der unteren Donau, Universitätsforschungen zur prähistorischen Archäologie 11/1-2, Habelt,1992.

Filipec 2012 - K. Filipec, Srednjovjekovno groblje i naselje Đakovo - župna crkva, Istraživanja Katedre za opću srednjovjekovnu i nacionalnu arheologiju, Monografije 1, Centar za ranosrednjovjekovna istraživanja Zagreb - Lobor, Odsjek za arheologiju Filozofskog fakulteta Sveučilišta u Zagrebu, 2012.

Giesler 1980 - J. Giesler, Zur Archäologie des Ostalpenraumes vom 8. bis 11. Jahrhundert, Archäologisches Korrespondenzblatt 10, 1980, 85-98.

Giesler 1981 - J. Giesler, Untersuchungen zur Chronologie der bijelo Brdo-Kultur (Ein Beitrag zur Archäologie des 10. und 11. Jahrhunderts im Karpatenbecken, Praehistorische Zeitschrif 56/1, De Gruyter, 1981.

Григоров 2007 - В. Григоров, Метални накити от средновековна Бьлгария (VIIXI в.), Дисертации 1, Национален археологически институт и музей - БАН, 2007. 
Istra i sjevernojadranski prostor 1995 - Istra i sjevernojadranski prostor u ranom srednjem vijeku (materijalna kultura od 7. do 11. stoljeća), Monografije i katalozi 4, Arheološki muzej Istre, 1995.

Jakšić 1989 - N. Jakšić, Crkve na Begovači i problem starohrvatskih nekropola, Diadora 11, 1989, 407-433.

Jelovina 1976 - D. Jelovina, Starohrvatske nekropole na području između rijeka Zrmanje i Cetine, Biblioteka znanstvenih djela 2, Čakavski sabor, 1976.

Jelovina 1982 - D. Jelovina, Starohrvatsko groblje na "Mastirinama" u selu Kašiću kod Zadra, Starohrvatska prosvjeta 12, 1982, 35-66.

Jelovina, Vrsalović 1981 - D. Jelovina, D. Vrsalović, Srednjovjekovno groblje na "Begovači" u selu Biljanima Donjima kod Zadra, Starohrvatska prosvjeta 11, $1981,55-135$.

Jovanović, Vuksan 2005 - S. Jovanović, M. Vuksan, Medieval Necropolis, in Petković, S., Ružić, M., Jovanović, S., Vuksan, M., Zoffmann, Zs. K. (eds.), Roman and Medieval Necropolis in Ravna near Knjaževac, Posebna izdanja 42, Arheološki institut Beograd, 2005

Kamenjarin 2009 - I. Kamenjarin, Bijaći - Stombrate, rezultati arheoloških istraživanja starohrvatskoga groblja, Starohrvatska prosvjeta 36, 2009, 85-111.

Karaman 1940 - Lj. Karaman, Iskopine društva "Bihaća” u Mravincima i starohrvatska groblja, Rad Jugoslavenske akademije znanosti i umjetnosti 268, 1940, 1-44.

Kefelja 2016 - M. Kefelja, Grozdasti uhani tipa 17 v prostoru in času, unpublished MA thesis, Univerza v Ljubljani, Filozofska fakulteta, Odelek za arheologijo, Ljubljana 2016, https://www.academia.edu/28703008/ (14 April 2021).

Kiss 1968 - A. Kiss, A sellyei Árpád-kori temetö, Janus Pannonius Múzeum Évkönyve 12, 1968, 69-72.

Korošec 1957 - J. Korošec, Slavenske naušnice sa spiralno uvijenim konusom na jednom kraju, Vjesnik za arheologiju i historiju dalmatinsku 56-59, 1957, 175-180.

Korošec 1969 - P. Korošec, Raziskave na Svetih gorah na Bizeljskem, Arheološki vestnik 20, 1969, 239-252.

Korošec 1979 - P. Korošec, Zgodnjesrednjeveška slika karantanskih Slovanov 1-2, Slovenska akademija znanosti in umetnosti, 1979

Korošec 1994 - P. Korošec, Kulturno vrednotenje najdb z grobišča v Köttlach pri Gloggnitzu, Razprave Filozofske fakultete, Znanstveni inštitut Filozofske fakultete, 1994 .

Манева 1992 - Е. Манева, Средновековен накит од Македонија, Културно -историско наследство на Република Македонија 28, Републички завод за заштита на спомениците на културата, 1992.

Marušić 1970 - B. Marušić, Kasnoantičko i ranosrednjovjekovno groblje kaštela Dvograd, Histria Archaeologica 1/1, 1970, 7-46.

Marušić 1987 - B. Marušić, Starohrvatska nekropola u Žminju, Arheološki muzej Istre, 1987.

Miletić 1975 - N. Miletić, Elementi della cultura di Koettlach in Bosnia e Erzegovina, Balcanoslavica 4, 1975, 93-111.

Miletić 1979 - N. Miletić, Slovenska nekropola u Mahovljanima kod Banjaluke, Glasnik Zemaljskog muzeja Bosne i Hercegovine 34, 1979, 137-160.

Минић 1970 - Д. Минић, Средњевековна некропола у Великом Градцу код Доњег Милановца, Старинар 20, 1970, 243-247.

Минић 1987 - Д. Минић, Спирално увијена жица на средњовековном накиту из Србије, Старинар 38, 1987, 73-81.

Nallbani 2017 - E. Nallbani, Early Medieval North Albania: New Discoveries, Remodeling Connections, The Case of Medieval Komani, in Gelichi, S., Negrelli, C. (Eds.), Adriatico altomedievale (VI-XI secolo), Scambi, porti, produzion, Studi e ricerche 4, Edizioni Ca' Foscari, 2017, 311-346.

Nowotny 2005 - E. Nowotny, Das Frühmittelalterliche Gräberfeld von Hohenberg, Steiermark, Archaeologia Austriaca 89, 2005, 177-250.
Petrinec 2009 - M. Petrinec, Groblja od 8. do 11. stoljeća na području ranosrednjovjekovne hrvatske države, Monumenta Medii Aevi Croatiae 3, Muzej hrvatskih arheoloških spomenika, 2009

Petrinec 2014 - M. Petrinec, 0 pojedinim predmetima bizantske provenijencije na istočnoj obali Jadrana, Starohrvatska prosvjeta 41, 2014, 63-98.

Petrinec 2015 - M. Petrinec, Frühmittelalterliche Gräber aus Orlić Angesichts Bisheriger Erkenntnisse über den Horizont mit Heidnischen Bestattungsmerkmalen, Starohrvatska prosvjeta 42, 2015, 81-131.

Petrinec 2019 - M. Petrinec, 0 nakitu iz Golubića i ženskoj nošnji iz razdoblja 8. i prve polovine 9. stoljeća / On jewellery from Golubić and female costumes from the eight and the first half of the ninth century, Starohrvatska prosvjeta $46,2019,45-166$

Радичевиђ 2007 - Д. Радичевиђ, Ка прецизнијем датовању средњовековног гробља на Великом Градцу, Гласник Српског арх. друштва 23, 2007, 87-102.

Radović 2010 - M. Radović, Starohrvatski grobovi otkriveni na položaju Banovac u Ninu / Early Croatian graves discovered at the site of Banovac in Nin, Diadora 24, 2010, 161-178.

Sekelj Ivančan 2010 - T. Sekelj Ivančan, Podravina u ranom srednjem vijeku, Mo nographie Instituti archaeologici 2, Institut za arheologiju, 2010.

Simoni 2004 - K. Simoni, Stenjevec starohrvatsko groblje, Arheološki muzej u Zagrebu, 2004

Sokol 2019 - V. Sokol, Hrvatska srednjovjekovna arheološka baština, Bibliotheca Historia Croatica 86, Meridijani, 2019.

Szekeres, Szekeres 1996 - L. Szekeres, Á. Szekeres, Szarmata és XI. századi temetök Verusicson. Subotica - Azotara, Szabadka,1996.

Szőke 1962 - B. Szőke, A honfogaló és kora Àrpád-kori magyarság régészeti emlékei, Régészeti tanulmányok 1, Akadémiai Kiadó,1962.

Szőke 1992 - B. M. Szőke, Karolingerzeitliche Gräberfelder I-II von GaraboncOfalu, Die Karolingerzeit im unteren Zalatal, Antaeus 21, 1992, 41-203.

Šmalcelj 2012 - P. Šmalcelj, Kulturni elementi na grobljima sjeverozapadne Bosne, Starohrvatska prosvjeta 39, 2012, 131-170.

Šmalcelj Novaković 2015 - P. Šmalcelj Novaković, Naušnice iz Privlake, Tipološ ka klasifikacija, unpublished seminar paper, Filozofski fakultet Sveučilišta u Zagrebu, Zagreb 2015

Tomičić 1992 - Ž. Tomičić, Neuere Erforschung der Bijelo-Brdo Kulturi n Kroatien, Prilozi Instituta za arheologiju 9, 1992, 113-130.

Ungerman 2016 - Š. Ungerman, „Karantánsko-köttlašský“ šperk na jihozápadním Slovensku a v dalších částech Karpatské kotliny, Přehled výzkumů $57 / 2,2016,11-48$.

Váňa 1954 - Z. Váňa, Mad aři a Slované va světle archeologických nálezů X. -XII. století, Slovenská archeológia 2, 1954, 51-104.

Vinski 1952 - Z. Vinski, Naušnice zvjezdolikog tipa u Arheološkom muzeju u Zagrebu s posebnim obzirom na nosioce srebrnog nakita Čađavica, Starohrvatska prosvjeta 2, 1952, 29-56.

Vinski 1970 - Z. Vinski, O postojanju radionica nakita starohrvatskog doba u Sisku, Vjesnik Arheološkog muzeja u Zagrebu 4, 1970, 45-91.

Вукосављевић 2012 - Н. Вукосављевић, Команска култура: основне одлике, порекло, распрострањеност и датовање, unpublished MA thesis, Филозофски факултет у Београду, Одељење за археологију, 2012, https://www.academia. edu/32602776/ (14 April 2021).

Зечевић 2006 - Е. Зечевић, Накит Новог Брда, Народни музеј у Београду, 2006.

Žeravica 1986 - Z. Žeravica, Ranoslovenska nekropola Bagruša u Petoševcima kod Laktaša, Glasnik Zemaljskog muzeja Bosne i Hercegovine u Sarajevu 40/41, 1986, 129-209. 